


DEPARTAMENTO DE DIREITO

\title{
A RAÇA DO GÊNERO? AS GUERREIRAS \\ DA ESTRADINHA E A LUTA PELO \\ DIREITO À MORADIA ADEQUADA
}

por

CAROLINA CÂMARA PIRES DOS SANTOS

ORIENTADOR(A): Márcia Nina Bernardes

2013.1

PONTIFÍCIA UNIVERSIDADE CATÓLICA DO RIO DE JANEIRO

RUA MARQUÊS DE SÃO VICENTE, 225 - CEP 22453-900.

RIO DE JANEIRO - BRASIL 


\section{A RAÇA DO GÊNERO? AS GUERREIRAS DA ESTRADINHA E A LUTA PELO DIREITO À MORADIA ADEQUADA \\ por}

CAROLINA CÂMARA PIRES DOS SANTOS

Monografia

apresentada

ao

Departamento de Direito da Pontificia Universidade Católica do Rio de Janeiro (PUC-Rio) para a obtenção do Título de Bacharel em Direito.

Orientador(a): Márcia Nina Bernardes

Co-Orientador(a): Vanessa Santos do Canto

2013.1 


\section{Dedicatória}

Ao meu pai David, por me ensinar a acreditar que sou capaz de cumprir tudo aquilo que eu determinar e ter fé em mim mesma.

À minha mãe Maria Luzia, meu maior exemplo de garra e superação, que com seu amor incondicional e dedicação me preparou para lutar por meus objetivos e superar os obstáculos advindos.

À minha tia Lia por sempre zelar pelo meu bemestar e se importar comigo, como se fosse minha segunda mãe.

Às mulheres negras, que desde a escravidão, jamais desistiram de lutar por seus direitos, lares, famílias e que a cada dia reúnem forças para resistir à violência a elas destinada. 
[...] Mais, um dia nóis nem pode se alembrá Veio os homi c'as ferramentas, o dono mandô derrubá. Peguemo todas nossas coisas e fumos pro meio da rua aprecia a demolição. Que tristeza que nóis sentia. Cada táuba que caía duia no coração [...] Saudosa maloca, maloca querida Dim dim donde nóis passemos os dias feliz de nossas vidas.

\section{Saudosa Maloca - Adoniran Barbosa}

Os políticos sabem que eu sou poetisa. E que o poeta enfrenta a morte quando vê seu povo oprimido.

Carolina Maria de Jesus

O racismo estabelece a inferioridade social dos segmentos negros da população em geral e das mulheres negras em particular, operando ademais como fator de divisão na luta das mulheres pelos privilégios que se instituem para as mulheres brancas.

\section{Sueli Carneiro}

$\mathrm{O}$ aço das novas correntes não aprisiona minha mente. Não me compra e não me faz mostrar os dentes. Mulher negra não se acostume com termo depreciativo. Não é melhor ter cabelo liso, nariz fino. Nossos traços faciais são como letras de um documento. Que mantém vivo o maior crime de todos os tempos. Fique de pé pelos que no mar foram jogados. Pelos corpos que nos pelourinhos foram descarnados. Não deixe que te façam pensar que o nosso papel na pátria é atrair gringo turista interpretando mulata. Podem pagar menos pelos mesmos serviços, atacar nossas religiões, acusar de feitiços. Menosprezar a nossa contribuição na cultura brasileira, mas não podem arrancar o orgulho de nossa pele negra. Mulheres negras são como mantas Kevlar. Preparadas pela vida para suportar. O racismo, os tiros, o eurocentrismo. Abalam, mas não deixam nossos neurônios cativos. 


\section{Agradecimentos}

A Deus, por me permitir vivenciar, a cada dia, os meus sonhos e possibilitar a conquista das minhas metas. "O Senhor é meu pastor, nada me faltará!"

Aos meus pais por todo amor a mim destinado e que, desde que eu era apenas uma criança, sempre me incentivaram a estudar e a vencer minhas batalhas.

Aos meus amigos-irmãos Caroline Lyrio, Alexandre Silva, Fernanda Souza, Rachel Lopes e Yuri Muniz, que conheci nesta universidade e estiveram ao meu lado tanto nos momentos mais difíceis, quanto nos momentos alegres, sempre me dando suporte e apoio, compartilhando o sentimento sublime que comporta a palavra amizade.

Aos amigos-guerreiros, da turma 2007.1, Elisiane Soares, Elaine Maria de Jesus, Samuel Kassawara, Emílio Farias e Diego Braga, não menos importante dos acima citados, dos quais me orgulho de ter conhecido suas histórias de vida e a honra de acompanhar o desenvolvimento acadêmico.

Aos professores Francisco de Guimaraens, Adriana Vidal, Thula Pires, Otávio Bravo, Alexandre Mendes, Mariana Trotta, Bethania Assy, João Batista Berthier, Elizabeth Sussekind, Maria Celina Bodin de Moraes, Augusto Werneck, Agnes Christian, Alexandre Assed e Regina Coeli, que além da excelência no transmitir de seus saberes, agregaram novos valores à minha formação profissional e pessoal, aumentando assim a minha capacidade de permanecer na luta a favor dos direitos humanos.

Às companheiras do grupo de estudos (PIBIC) sobre Gênero, Maria Fernanda Marques e Maria Negreiros, por todo o conhecimento adquirido e compartilhado e pela agradável companhia que sempre me proporcionaram.

A todos os estagiários e defensores públicos do Núcleo de Terras e Habitação da Defensoria Pública pela troca de saberes e experiências e por reforçar a militância pela efetivação do direito à moradia. E ao Dr. Maurício Campos por ter me cedido gentilmente o material técnico para a pesquisa.

À Sra. Maria de Fátima Amorim e a todas as moradoras da Comunidade da Estradinha, que me receberam de braços abertos e me permitiram contar suas histórias e lutas.

Por fim, gostaria de fazer um agradecimento especial às minhas orientadoras Márcia Nina Bernardes e Vanessa Santos do Canto. Agradeço por acreditar no meu talento e no meu projeto, por compartilhar seus saberes, pelo apoio e incentivo durante a minha vida acadêmica, por me ouvir com atenção e por sempre me lembrar da minha capacidade nos momentos em que me senti vulnerável. Sou grata, de coração, a tudo o que fizeram por mim! 


\section{Resumo}

A cidade do Rio de Janeiro, que sediará dois megaeventos esportivos, a Copa do Mundo 2014 e as Olimpíadas 2016, tem sido palco de diversos conflitos fundiários urbanos, nos quais as favelas localizadas em diferentes pontos do município são os principais alvos das atuais políticas de remoção. Sendo assim, para atender aos interesses da especulação imobiliária, o poder público tende a violar o direito à moradia, assegurado como fundamental pela Carta Magna de 1988, ignorando inclusive as normas e princípios internacionais de direitos humanos. Nesse contexto, de luta pelo direito à moradia adequada, é possível perceber que as mulheres moradoras de favelas são afetadas diretamente pelas remoções, tendo em vista que sua participação no âmbito doméstico, ainda que trabalhem fora de casa, é superior à masculina. Considerando que as favelas abrigam um grande contingente da população afrodescendente do município, de acordo com o Censo 2010, é necessário pensar de que forma as remoções atuam no desempoderamento dessas mulheres. Este trabalho se propõe a compreender a política de remoção dentro da perspectiva da teoria da interseccionalidade, tomando por objeto de estudo o caso da Comunidade da Estradinha, relacionando as diferentes formas de discriminação envolvidas nesta questão, além de mostrar os impactos desta política pública na vida dessas mulheres e o seu protagonismo na luta pelos seus direitos.

Palavras-chave: gênero, raça, moradia, favela, remoção, interseccionalidade 


\section{Sumário}

INTRODUÇÃO

Parte 1

1. Direito à Moradia e as Desigualdades de Gênero e Raça...................... 13

1.1. A invisibilidade a partir da Teoria da Interseccionalidade: a relação das opressões de gênero, classe e raça produzindo a vulnerabilidade ........ 13

1.2. O Direito à Moradia no Plano Internacional .................................... 24

1.3. O Direito à Moradia no Brasil ........................................................ 35

Parte 2

2. Os Caminhos da Estradinha.............................................................. 45

2.1. Histórico da Comunidade da Estradinha ......................................... 45

2.2. Aspectos Demográficos e Dados Socioeconômicos. .......................... 53

2.3. Especulação imobiliária: os descaminhos da Estradinha ....................61 61

3. A Raça do Gênero? As Guerreiras da Estradinha e a luta pelo

Direito à Moradia Adequada ............................................................... 72

3.1. Quem são as guerreiras da Estradinha? ............................................ 72

3.2. Guerreiras não tem medo de ameaça: a luta contra as remoções ......... 80

3.3. Um longo caminho a percorrer: A Estradinha construída na raça



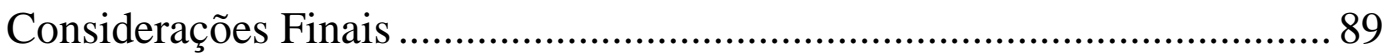

Referências bibliográficas .......................................................... 91

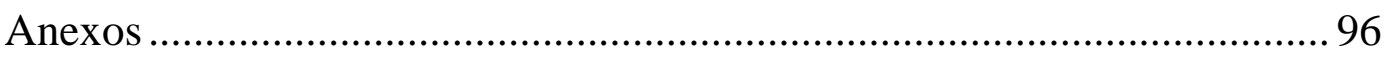




\section{Lista de siglas e abreviações}

AEIS - Área de Especial Interesse Social

APA - Área de Proteção Ambiental

ART. - Artigo

CEDAW - Convenção sobre a Eliminação de Todas as Formas de Discriminação contra a Mulher

CREA - Conselho Regional de Engenharia e Arquitetura

CERD - Convenção sobre a Eliminação de Todas as Formas de

Discriminação Racial

DUDH - Declaração Universal dos Direitos Humanos

GEO-RIO - Instituto de Geotécnica do Município do Rio de Janeiro

IPP - Instituto Municipal de Urbanismo Pereira Passos

NUTH - Núcleo de Terras e Habitação da Defensoria Pública

OHCHR - Alto Comissariado das Nações Unidas sobre Direitos Humanos

ONU - Organização das Nações Unidas

ONU-HABITAT - Programa das Nações Unidas para os Assentamentos Humanos

PLANAPIR - Plano Nacional de Promoção da Igualdade Racial

PNPIR - Política Nacional de Promoção da Igualdade Racial

PNPM - Plano Nacional de Políticas para as Mulheres

SABREN - Sistema de Assentamentos de Baixa Renda

SEPPIR - Secretaria de Políticas de Promoção da Igualdade Racial

SMH - Secretaria Municipal de Habitação

SMU - Secretaria Municipal de Urbanismo

SPM - Secretaria Especial de Políticas para as Mulheres 


\section{Lista de fotos, tabelas e gráficos}

FIGURA 01 - Localização da Ladeira dos Tabajaras

FIGURA 02 - Histórico da Ladeira dos Tabajaras

FIGURA 03 - Localização da Ladeira dos Tabajaras

FIGURA 04 - Identificação Alternativa da Ladeira dos Tabajaras

FIGURA 05 - Localização da Ladeira dos Tabajaras

FIGURA 06 - Localização da Ladeira dos Tabajaras

FIGURA 07 - Obras de contenção na Ladeira dos Tabajaras

FIGURA 08 - Obras de contenção na Ladeira dos Tabajaras

FOTO 09 - Obras de contenção na Ladeira dos Tabajaras (Programa Favela-Bairro)

FIGURA 10 - Obras de contenção na Ladeira dos Tabajaras (Programa Favela-Bairro)

FIGURA 11 - Desabamento na Ladeira dos Tabajaras (Cemitério São João Batista)

FIGURA 12 - Desabamento na Ladeira dos Tabajaras (Cemitério São João Batista)

GRÁFICO 01 - Diagrama Interseccional de Discriminação

GRÁFICO 02 - População residente por sexo e idade

GRÁFICO 03 - População residente por cor ou raça

GRÁFICO 04 - Domicílios particulares segundo o tipo e condição de ocupação

GRÁFICO 05 - Quantidade de moradores por domicílios particulares permanentes

TABELA 01 - Domicílios particulares em aglomerados subnormais, população residente por sexo e media de moradores 


\section{INTRODUÇÃO}

A cidade do Rio de Janeiro, que sediará dois megaeventos esportivos, a Copa do Mundo 2014 e as Olimpíadas 2016, tem sido palco de diversos conflitos fundiários urbanos, nos quais favelas localizadas em diferentes pontos do município são os principais alvos das atuais políticas de remoção. O poder público não demonstra maiores preocupações com o desenvolvimento de projetos e políticas que incluam a população moradora dessas localidades dentro da estrutura exigida pelo Comitê Olímpico. E, por outro lado, não está sensível aos impactos negativos causados pelas remoções na vida da população moradora dessas áreas.

Desta maneira, a Prefeitura Municipal do Rio de Janeiro, apoiada pelo governo do Estado, vem empreendendo diversas estratégias para forçar os moradores a sair das comunidades. Utilizam argumentos questionáveis, como por exemplo, alega que a construção dos imóveis se deu de forma irregular, e que, portanto, eles não teriam direito a permanecer no local. Outro argumento bastante utilizado é que as casas foram construídas em área de risco, mas como se verá adiante, os laudos preparados pelos engenheiros da prefeitura são entregues sem nenhuma verificação técnica prévia no local.

Sendo assim, para atender aos interesses da especulação imobiliária, o poder público tende a violar o direito à moradia, assegurado como fundamental pela Carta Magna de 1988, ignorando inclusive as normas, princípios e diretrizes internacionais de direitos humanos. O conceito de moradia adequada, estabelecido e defendido pela Organização das Nações Unidas (ONU), desaparece frente ao descaso das autoridades no processo de desapropriação, o qual ocorre de forma acelerada e ilegal, na maior parte dos casos, devido aos prazos e metas estipulados pelo Comitê Olímpico para entrega dos espaços onde serão realizados os eventos esportivos.

Dentro do movimento de resistência a essa política de remoção, lideranças das favelas lutam contra a realocação dos moradores em locais 
muito distantes e, na maioria das vezes, sem infraestrutura e disponibilidade de serviços, além da ausência de equipamentos públicos. $\mathrm{O}$ acesso à rede pública de ensino, aos serviços de saúde, a variedade e quantidade dos meios de transporte, por exemplo, torna-se limitado porque estes locais não dispõem de uma estrutura adequada para abrigar a população deslocada. Tais fatores causam inúmeros transtornos à demanda removida, dificultando assim a sua condição de vida.

É importante observar que este trabalho surge das minhas observações enquanto estagiária do Núcleo de Terras e Habitação da Defensoria Pública do Estado do Rio de Janeiro (NUTH). A função deste órgão, dentre outras, é defender por meio de processos judiciais e administrativos coletivos, o direito à moradia das populações que moram nas favelas cariocas. Desta maneira, o NUTH atua de forma muito peculiar e diferente dos demais núcleos da referida instituição. Sua atribuição é definida conforme o número de famílias envolvidas no caso apresentado ao núcleo, o que significa que para ser atendida, a comunidade precisa ter no mínimo 10 (dez) famílias. Até abril de 2011, 274 (duzentas e setenta e quatro) comunidades, somando um total aproximado de 99.035 (noventa e nove mil e trinta e cinco) famílias, eram atendidas pelo NUTH.

Inicialmente era marcado um atendimento com uma comissão formada por representantes das comunidades a fim de que fossem relatados os problemas enfrentados. Posteriormente, os defensores e estagiários se reuniam para elaborar a melhor estratégia de enfrentamento e se necessário fosse entrariam com a ação cabível ao caso apresentado. É importante destacar que o trabalho, no órgão acima citado, era realizado por uma equipe composta por 05 (cinco) defensores públicos e 25 (vinte e cinco) estagiários, os quais cursavam graduação em Direito. Há que se destacar que o núcleo trabalhava em parceria com as comunidades, ouvindo seus questionamentos e até mesmo suas sugestões, estabelecendo um diálogo aberto e franco com os moradores. 
A experiência enquanto estagiária do NUTH me fez perceber que a maior parte do público que procurava a assistência jurídica era composta por mulheres preocupadas com as consequências das remoções. Nesse contexto, de luta pelo direito à moradia, é possível perceber que as mulheres moradoras de favelas são afetadas diretamente pelas remoções, tendo em vista que sua participação no âmbito doméstico, ainda que trabalhem fora de casa, é superior à masculina. Considerando que as favelas abrigam um grande contingente da população afrodescendente do município, de acordo com o Censo 2010, é necessário pensar de que forma as remoções atuam no desempoderamento dessas mulheres. Inclusive esta preocupação já foi abordada na Cartilha lançada recentemente pela ONU HABITAT, "Como fazer valer o Direito das Mulheres à Moradia?", na qual são expostos o conceito de moradia adequada, os elementos que o compõem e os fatores que vulnerabilizam a população feminina dentro do contexto de remoção.

Ao compartilhar do mesmo destino de várias comunidades cariocas, a Favela da Estradinha se estabelece como exemplo de luta pelo direito à moradia adequada, resistindo bravamente às investidas do poder munícipe. Localizada na zona sul da cidade, área considerada como nobre, a Favela da Estradinha está situada entre os bairros de Botafogo e Copacabana, sendo nomeada também como Morro São João, por estar próxima ao cemitério São João Batista. É importante ressaltar que o espírito de resistência é desenvolvido e mantido pelas lideranças femininas da comunidade, que cientes de seus direitos, se organizaram, a fim de lutar para permanecer em seus lares.

Assim, o presente trabalho se propõe a compreender a política de remoção dentro da perspectiva da teoria da interseccionalidade, tomando por objeto de estudo a Comunidade da Estradinha, relacionando as diferentes formas de discriminação envolvidas nesta questão, além de

${ }^{1}$ Disponível em: http://direitoamoradia.org/?p=4671\&lang=pt. Acessado em 26/03/2013. 
mostrar os impactos desta política pública na vida dessas mulheres e o seu protagonismo na luta pelos seus direitos.

Desta maneira, no primeiro capítulo será discutida a relação entre o Direito à Moradia e a Teoria da Interseccionalidade, observando as formas de discriminação que se inter-relacionam e as legislações que regem o universo deste direito tanto em âmbito nacional, quanto internacional. No segundo capítulo serão abordados o contexto histórico da Comunidade da Estradinha, seus aspectos demográficos e socioeconômicos e a análise do conceito de área de risco. Por fim, o terceiro capítulo se destinará à reflexão sobre o protagonismo das mulheres da Estradinha, utilizando como referência as entrevistas realizadas com as principais lideranças, e ressaltando suas estratégias para se defender das arbitrariedades exercidas pelo Município. 


\section{Direito à Moradia e as Desigualdades de Gênero e Raça}

O Direito à Moradia é considerado atualmente um direito fundamental constitucional, garantido na Carta Magna de 1988. Ou seja, é um direito imprescindível para a obtenção da cidadania plena dos brasileiros e brasileiras. A sua relevância foi reconhecida no plano internacional, pela Organização das Nações Unidas, a ONU, desde o ano de 1948, com o advento da Declaração Universal dos Direitos Humanos ${ }^{2}$. Desde então, foi reconhecido como direito humano fundamental, dada sua extrema importância, e a ONU, por sua vez, elaborou outros documentos internacionais a fim de garantir a sua implementação e efetivação.

A partir dessas considerações, o presente capítulo discorrerá sobre as questões que permeiam o universo do Direito à Moradia no Brasil. Nesse sentido, partira da análise das legislações internacionais e nacionais protetivas, sob a ótica da teoria da interseccionalidade. O objetivo consiste em mostrar que a vulnerabilidade dos casos de remoção aumenta quando se relacionam os conceitos de raça e gênero. Desta maneira, ilustra que a política de remoção impacta, de forma considerável, a vida das mulheres negras, moradoras de favelas e que os fatores acima relacionados contribuem significativamente para a sua vulnerabilidade, ocasionando o seu desempoderamento.

\subsection{A invisibilidade a partir da Teoria da Interseccionalidade: a relação das opressões de gênero, classe e raça produzindo a vulnerabilidade}

A Teoria da Interseccionalidade busca desvendar como a vulnerabilidade se intensifica à medida que são correlacionadas opressões

\footnotetext{
${ }^{2}$ Disponível em: http://direitoamoradia.org/?page_id=46\&lang=pt. Acessado em 26/03/2013.
} 
distintas. Considerando tais perspectivas, Kimberlé Crenshaw ${ }^{3}$ utiliza esta teoria em seus trabalhos de pesquisa que se inserem no âmbito da Teoria Crítica da Raça ${ }^{4}$, sendo sua principal representante. Na verdade, Crenshaw é uma das responsáveis pelo desenvolvimento teórico do conceito de intersecção das desigualdades de gênero e raça ${ }^{5}$. No entanto, antes de adentrar tal universo, é imprescindível compreender os conceitos de discriminação baseada em raça, gênero e classe, a fim de alcançar a teoria da interseccionalidade com clareza.

O debate em torno da discriminação em relação ao gênero foi inserido na agenda do movimento feminista, nos meados da década de 80 , tendo em vista que o conceito de discriminação baseada no sexo, expresso na Convenção sobre a Eliminação de Todas as Formas de Discriminação contra a Mulher (CEDAW), de 1979, documento da ONU, não abarcava de forma precisa, as demandas dos grupos cuja representação política é minoritária, como por exemplo, gays, lésbicas e transexuais. Desta maneira, as feministas perceberam que este conceito restringia o campo de alcance das vítimas desse tipo de opressão, enquanto a concepção de gênero o ampliava. Segundo a autora Joan Scott ${ }^{6}$, gênero é um elemento constitutivo de relações sociais, baseado nas diferenças percebidas entre os $\operatorname{sexos}^{7}$, constituindo assim uma ruptura, uma rejeição ao determinismo biológico

\footnotetext{
${ }^{3}$ É professora de Direito da Universidade da Califórnia e da Universidade de Columbia, nos Estados Unidos da América, sendo considerada como importante pesquisadora e ativista norteamericana nas áreas dos direitos civis, da teoria legal afro-americana e do feminismo.

${ }^{4}$ A Teoria Crítica da Raça propõe o mapeamento da relação entre raça e o Direito, observando que este último produz, constrói e constitui o que se entende por raça, não só em domínios onde raça é explicitamente articulada, mas também onde não é mencionada ou desconhecida. Outro objetivo é examinar as justificativas que determinam quando a raça é ou deve ser evidente, não pretendendo apenas entender a relação entre raça, poder e Direito, como também modificá-la. HARRIS, Cheryl I. Critical Race Studies: An Introduction. UCLA Law Review. 2002. p. 01. Disponível em: https://litigationessentials.lexisnexis.com/webcd/app?action=DocumentDisplay\&crawlid=1\&docty pe $=$ cite $\&$ docid $=49+$ UCLA + L. + Rev. $+1215 \&$ srctype $=$ smi $\&$ srcid $=3 B 15 \& k e y=3127 \mathrm{~cd} 1 \mathrm{~b} 79 \mathrm{a} 76 \mathrm{a} 9 \mathrm{aa}$ 6ac89d99bf7a725. Acessado em 15/04/2013.

${ }^{5}$ CRENSHAW, Kimberle. A Interseccionalidade da Discriminação de Raça e Gênero. p.7. Disponível em: http://static.tumblr.com/7symefv/V6vmj45f5/kimberle-crenshaw.pdf. Acessado em: 12/03/2013.

${ }^{6}$ Historiadora norte-americana e Professora do Instituto para Estudos Avançados (Institute for Advanced Studies) da Universidade de Princeton, New Jersey, Estados Unidos. Disponível em: http://www.ias.edu/people/faculty-and-emeriti/scott. Acessado em: 19/04/2013.

${ }^{7}$ SCOTT, Joan. Gênero: Uma Categoria Útil para Análise Histórica. p. 21. Disponível em: http://wesleycarvalho.com.br/wp-content/uploads/G\%C3\%AAnero-Joan-Scott.pdf. Acessado em 19.04.2013.
} 
implícito no uso de termos como "sexo" ou "diferença sexual". Scott afirma que é preciso "rejeitar o caráter fixo e permanente da oposição binária", pois "a história do pensamento feminista é uma história de recusa da construção hierárquica da relação entre masculino e feminino ${ }^{10 "}$.

Portanto, a definição do conceito da palavra gênero abrange as diversas identidades existentes entre o feminino e o masculino. Sendo assim, é possível ampliar a definição de discriminação contra a mulher, trazida pelo artigo $1^{\circ}$ da $\mathrm{CEDAW}^{11}$ :

Artigo $1^{\circ}$ - Para fins da presente Convenção, a expressão "discriminação contra a mulher" significará toda distinção, exclusão ou restrição baseada no sexo e que tenha por objeto ou resultado prejudicar ou anular o reconhecimento, gozo ou exercício pela mulher, independentemente de seu estado civil, com base na igualdade do homem e da mulher, dos direitos humanos e liberdades fundamentais nos campos político, econômico, social, cultural e civil ou em qualquer outro campo.

Scott afirma ainda que as categorias "homem" e "mulher" são totalmente vazias e transbordantes. Isso porque tais categorias não possuem significado algum e, além disso, ainda que fixadas, "contêm dentro delas definições alternativas negadas ou reprimidas ${ }^{12}$." Desta maneira, a discriminação baseada em gênero dilata a noção de discriminação baseada no sexo, tendo em vista que não se prende ao modelo binário "homem/mulher" e inclui as variedades de identidades do sujeito, possibilitando uma maior proteção aos direitos que a Convenção visa proteger.

Considerando as breves reflexões acerca da discriminação baseada em gênero, a partir deste momento será discutido o conceito de discriminação racial, que se apresenta na sociedade como outra forma de subordinação. Primeiramente, é importante lembrar que o conceito moderno

\footnotetext{
${ }^{8}$ Ibid. p. 3.

${ }^{9}$ Ibid. p. 19 .

${ }^{10}$ Ibid. p. 19.

${ }^{11}$ Convenção sobre a Eliminação de Todas as Formas de Discriminação contra a Mulher (CEDAW). Disponível em: http://www.pge.sp.gov.br/centrodeestudos/bibliotecavirtual/instrumentos/discriraci.htm. Acessado em 19/04/2013.

${ }^{12}$ SCOTT, Joan. Gênero: Uma Categoria Útil para Análise Histórica. p. 28. Disponível em: http://wesleycarvalho.com.br/wp-content/uploads/G\%C3\%AAnero-Joan-Scott.pdf. Acessado em 19/04/2013.
} 
de raça surge nas Ciências Naturais, sendo utilizado por zoólogos e botânicos para classificar plantas e animais. Posteriormente, a raça foi usada para classificar a diversidade humana, porém, segundo Kabengele Munanga $^{13}$, esta foi hierarquizada, permitindo assim um caminho para o racialismo $^{14}$. Surge, assim, a raciologia, cujo objetivo era manter a hierarquização das raças para justificar e legitimar os sistemas de dominação racial $^{15}$.

Inúmeras pesquisas ao redor do mundo já comprovaram que não existem, biologicamente, raças diferentes, definindo apenas uma raça: a humana $^{16}$. No entanto, isso não foi suficiente para modificar a estrutura racial estabelecida dentro da sociedade, pois trata-se de um conceito carregado de ideologia que esconde as relações de poder e de dominação ${ }^{17}$. Dividir a humanidade em raças distintas e hierarquizá-las, ou seja, conferir a determinadas raças um alto grau de importância e inteligência, de acordo com suas características, em detrimento de outras, configuram a base para o estabelecimento e permanência dos ideais racistas. Sendo assim, o racismo se difunde por volta de 1920 e, segundo Munanga, é definido como:

[...] ideologia essencialista que postula a divisão da humanidade em grandes grupos chamados raças contrastadas que têm características físicas hereditárias comuns, sendo estas últimas suportes das características psicológicas, morais, intelectuais e estéticas e se situam numa escala de valores desiguais. Visto deste ponto de vista, o racismo é uma crença na existência das raças naturalmente hierarquizadas pela relação intrínseca entre o físico e o moral, o físico e o intelecto, o físico e o cultural. [...]De outro modo, o racismo é essa tendência que

\footnotetext{
${ }^{13}$ Antropólogo especialista em relações raciais no Brasil. Doutor em Antropologia pela USP, foi professor durante 32 anos da Faculdade de Filosofia, Letras e Ciências Humanas da USP. Disponível em: http://antropologiausp.blogspot.com.br/2010/10/kabengele-munanga.html. Acessado em: 20/04/2013.

${ }^{14}$ MUNANGA, Kabengele. Uma Abordagem Conceitual das Noções de Raça, Racismo, Identidade e Etnia. p. 2. Disponível em: http://www.geledes.org.br/component/rsfiles/download?path=Umaabordagem-conceitual-das-nocoes-de-raca-racismo-dentidade-e-etnia.pdf\&Itemid=573. Acessado em: 16/03/2013.

${ }^{15}$ Ibid. p. 5.

${ }^{16}$ O Projeto Genoma Humano comprovou esta assertiva. Este projeto - um consórcio científico exclusivo dos países ricos - iniciado em 1990, visou mapear e sequenciar o código genético e elaborar o mapa dos genes humanos. Como resultado, identificou que existe apenas a raça humana, aniquilando o argumento do racismo biológico. OLIVEIRA, Fátima. Indagações e reflexões feministas sobre o Projeto Genoma Humano. Reunión de Expertos sobre Globalización, Cambio Tecnológico y Equidad de Género. São Paulo, 2001. p.02. Disponível em: http://www.eclac.org/mujer/noticias/noticias/0/8260/fatima_oliveira.pdf. Acessado em $19 / 04 / 2013$.

${ }^{17}$ Ibid. p. 6.
} 
consiste em considerar que as características intelectuais e morais de um dado grupo, são consequências diretas de suas características físicas ou biológicas ${ }^{18}$.

Munanga retrata com clareza, no trecho acima, que o racismo se fundamenta na crença de uma hierarquia natural, o que fortalece e legitima a dominação racial. A discriminação baseada no conceito de raça foi responsável pelos piores genocídios da história: a dizimação dos judeus durante a Segunda Guerra Mundial e a dos negros no período da escravidão. Sendo assim, a discriminação racial é algo que não pode ser tolerado pela sociedade moderna, entretanto, o racismo ainda produz efeitos muito perversos no presente. Com o intuito de combater o racismo, a ONU promulga a Convenção Sobre a Eliminação de Todas as Formas de Discriminação Racial (CERD), na qual todos os países que a ratificarem, deverão tomar medidas para eliminar qualquer ato de racismo em seus territórios. $\mathrm{O}$ art. $1^{\mathrm{o}}$ deste documento descreve o que se entende por discriminação racial:

Artigo $1^{\circ}$ - Para os fins da presente Convenção, a expressão "discriminação racial" significará toda distinção, exclusão, restrição ou preferência baseada em raça, cor, descendência ou origem nacional ou étnica que tenha por objeto ou resultado anular ou restringir o reconhecimento, gozo ou exercício em um mesmo plano (em igualdade de condição) de direitos humanos e liberdades fundamentais nos campos político, econômico, social, cultural ou em qualquer outro campo da vida pública ${ }^{19}$.

Neste momento, após recapitulação sobre os conceitos de raça e racismo e, por conseguinte, da discriminação racial, é importante relembrar o conceito de discriminação baseada em classe social. É necessário, inicialmente discorrer brevemente sobre o conceito de classe. Na verdade, a teoria de classe surge com a abordagem marxista sobre a luta de classes ${ }^{20}$. Entretanto, nos aproximamos da abordagem elaborada por Max Weber.

\footnotetext{
${ }^{18}$ Ibid. p. 7-8.

${ }^{19}$ Convenção sobre a Eliminação de Todas as Formas de Discriminação Racial (1968). Disponível em: $\quad$ http://www.pge.sp.gov.br/centrodeestudos/bibliotecavirtual/instrumentos/discriraci.htm. Acessado em: 22/03/2013.

${ }^{20}$ GUIMARÃES, Antônio Sérgio. Classes, Raça e Democracia. p.35-36. Disponível em: http://books.google.com.br/books?id=k7cEzL4awMAC\&pg=PP4\&lpg=PP4\&dq=classes, + ra\% $\%$ \% $\mathrm{A} 7 \mathrm{a}+$ edemocracia+antonio+sergio+guimar $\% \mathrm{C} 3 \% \mathrm{~A} 3 \mathrm{es} \&$ source $=\mathrm{bl} \& \mathrm{ots}=511 \mathrm{CCuDv} \& \mathrm{sig}=\mathrm{SPIEM}$ v9vogx69imZXsIVZjzyo\&hl=pt\&sa=X\&ei=v8p1UcCPDaeV0QGcp4DABA\&redir_esc=y. Acessado em: 18/03/2013.
} 
Nesse sentido, concordamos com Antônio Sérgio Guimarães, para quem a classe social possui o "sentido de um carisma ou estigma, significando o prestígio social associado a uma pertença grupal ${ }^{21}$ ". Desta maneira, entende-se por discriminação de classe social, a exclusão com base no status que o indivíduo ocupa na sociedade. Assim, a pobreza gera o estigma que funciona como motivação para a discriminação baseada em classe, por ser considerada como um status social específico, inferior e desvalorizado $^{22}$. Tal assertiva é conceituada e medida em função de carências ou necessidades básicas insatisfeitas, utilizando indicadores como a ingestão de alimentos, os níveis de ingresso, o acesso à saúde, à educação e à moradia ${ }^{23}$. Isto significa que as pessoas pobres se encontram em situação de vulnerabilidade, tendo em vista que são discriminadas pela sua posição social.

Portanto, considerando a abordagem inicial sobre os conceitos de discriminação baseada em gênero, raça e classe, é possível aprofundar, a seguir, na teoria da interseccionalidade, a fim de compreender como um sujeito ou grupo social pode se tornar mais vulnerável, à medida que distintos tipos de opressão interagem entre si aprofundando o processo de subordinação. A interseccionalidade é um conceito que surge no centro dos debates feministas norte-americanos entre as décadas de 1960 e 1970, originando-se da "reflexão sociológica acerca da relação entre as diversas

\footnotetext{
${ }^{21}$ GUIMARÃES, Antônio Sérgio. Classes, Raça e Democracia. p.35-36. Disponível em: http://books.google.com.br/books?id=k7cEzL4awMAC\&pg=PP4\&lpg=PP4\&dq=classes, + ra\%C \% $\mathrm{A} 7 \mathrm{a}+$ edemocracia+antonio+sergio+guimar $\% \mathrm{C} 3 \% \mathrm{~A} 3 \mathrm{es} \&$ source $=\mathrm{bl} \& \mathrm{ots}=511 \mathrm{CCuDv} \& \mathrm{sig}=\mathrm{SPIEM}$ v9vogx69imZXsIVZjzyo\&hl=pt\&sa=X\&ei=v8p1UcCPDaeV0QGcp4DABA\&redir_esc=y. Acessado em: 18/03/2013.

${ }^{22}$ PAUGAM, Serge. Desqualificação Social: Ensaio sobre a nova pobreza. São Paulo. Ed. Cortez, 2003. p.45.

${ }^{23}$ ARRIAGADA, Irma. Dimensiones de la pobreza y políticas desde uma perspectiva de gênero. Reunión de Expertos "Políticas y programas de superación de la pobreza desde la perspectiva de la gobernabilidad democrática y el género". Comisión Económica para América Latina y el Caribe - CEPAL. 2004. p.02. Disponível em: http://www.cepal.org/mujer/reuniones/quito/IArriagada2.pdf
} 
formas de discriminação ou desvantagens estruturais, como raça, gênero ou classe social $^{24,}$.

Kimberlé Crenshaw, principal autora de artigos e pesquisa sobre o assunto, afirma que as leis e as políticas públicas nem sempre conseguem abarcar as categorias de opressão, principalmente quando elas perpassam entre si, de modo que a teoria da interseccionalidade tem o desafio de abordar as diferenças dentro das diferenças ${ }^{25}$. Muitas vezes, a discriminação de gênero resta implícita diante de uma situação de discriminação racial e vice-versa, e, então, a vítima tem o seu direito violado, não sendo alcançada pelas legislações de proteção dos direitos humanos. Quando a discriminação não se encaixa no modelo-padrão definido pelas leis protetivas de gênero ou de raça, tende a ser compreendida como extremamente diversa das experiências formais e desta maneira, não é assimilada como uma violação aos direitos humanos ${ }^{26}$. Segundo Crenshaw, "a interseccionalidade sugere que nem sempre lidamos com grupos distintos de pessoas e sim com grupos sobrepostos ${ }^{27}$ ". Portanto, “é preciso identificar melhor o que acontece quando várias formas de discriminação se combinam e afetam as vidas de determinadas pessoas ${ }^{28,}$.

A autora defende que as mulheres, já sujeitas à discriminação de gênero, podem também sofrer outros tipos de opressão de acordo com os "fatores relacionados às suas identidades sociais, tais como classe, casta, raça, cor, etnia, religião, origem nacional e orientação sexual" 29 , o que

\footnotetext{
${ }^{24}$ HOFFMANN, Florian. Interseccionalidade Sistêmica? Breves Comentários Sobre a Luta Contra a Discriminação Racial no Âmbito Internacional. In: Notícias e Reflexões Sobre Discriminação Racial. Ed. PUC-RIO, 2008. p. 105.

${ }^{25}$ CRENSHAW, Kimberle. A Intersecionalidade da Discriminação de Raça e Gênero. p.9. Disponível em: http://static.tumblr.com/7symefv/V6vmj45f5/kimberle-crenshaw.pdf. Acessado em: 12/03/2013.

${ }^{26}$ CRENSHAW, Kimberle. Documento para o Encontro de Especialistas em Aspectos da Discriminação Racial relativos ao Gênero. 2002. p.172. Disponível em: http://www.scielo.br/pdf/ref/v10n1/11636.pdf. Acessado em: 22/03/2013.

${ }^{27}$ CRENSHAW, Kimberle. A Intersecionalidade da Discriminação de Raça e Gênero. p.9. Disponível em: http://static.tumblr.com/7symefv/V6vmj45f5/kimberle-crenshaw.pdf. Acessado em: 12/03/2013.

${ }^{28}$ Ibid. p.11.

${ }^{29}$ CRENSHAW, Kimberle. Documento para o Encontro de Especialistas em Aspectos da Discriminação Racial relativos ao Gênero. 2002. p.173. Disponível em: http://www.scielo.br/pdf/ref/v10n1/11636.pdf. Acessado em: 22/03/2013.
} 
portanto estabelecem vulnerabilidades específicas para determinados grupos de mulheres. É imprescindível perceber as categorias de invisibilidade intersecional, sugeridas por Crenshaw, para entender de que forma as mulheres se tornam fragilizadas diante da interseção. $\mathrm{O}$ diagrama abaixo exemplifica como as categorias de discriminação se sobrepõem:

\section{GRÁFICO 01 - Diagrama Interseccional de Discriminação}

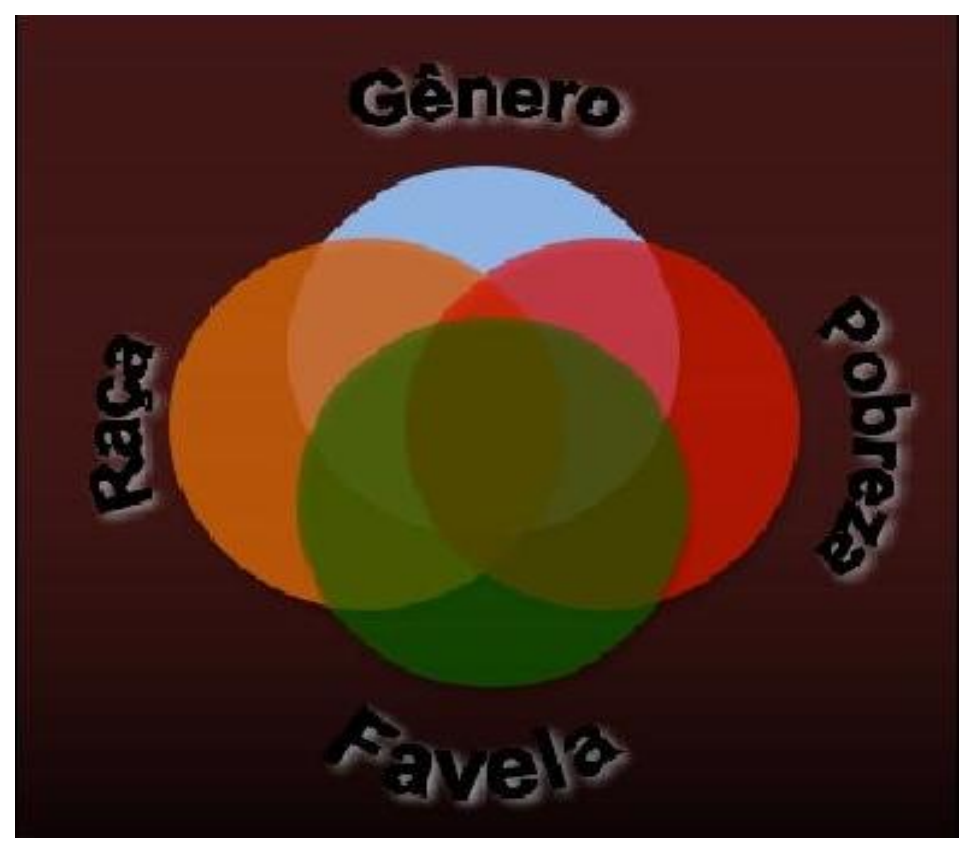

Fonte: Crenshaw, Kimberlé. A Intersecionalidade da Discriminação de Raça e Gênero. p.10.

Existem duas categorias problemáticas dentro do modelo intersecional: a superinclusão e a subinclusão. A superinclusão ocorre quando os aspectos de uma determinada situação de subordinação, que a tornam intersecional, são absorvidos pela estrutura de gênero, sem reconhecer o viés racista ou de outra forma de discriminação exercida naquela circunstância ${ }^{30}$. Desta maneira, esta discriminação é entendida de forma universal, como um problema das mulheres em geral e não como um problema específico de mulheres pertencentes a uma determinada etnia ou raça, por exemplo. Já a subinclusão.ocorre quando um subgrupo de mulheres enfrenta um problema de gênero, mas não é reconhecido como tal porque as mulheres dos grupos dominantes não passam por esta mesma

\footnotetext{
${ }^{30}$ Ibid. p. 174 .
} 
experiência $^{31}$. Há também uma outra forma de subinclusão, a qual ocorre quando as mulheres de determinado grupo racial ou étnico não tem seu problema específico reconhecido porque não atinge os homens desse mesmo contingente. Tal acontecimento ocasiona uma invisibilidade de gênero dentro de uma questão de raça ou etnia ${ }^{32}$.

Crenshaw identifica de forma precisa esses dois problemas, citando o tráfico de mulheres como exemplo da superinclusão e a esterilização forçada de mulheres marginalizadas que corresponde à subinclusão. Embora o tráfico de mulheres seja realmente uma questão de gênero, não se discute outras formas de discriminação, como raça ou classe, ou ainda outros modos de subordinação relacionados. A autora afirma que no relatório do Comitê sobre a Condição das Mulheres não existe nenhuma menção a outras formas de subordinação, as quais podem aumentar a probabilidade de que certas mulheres estejam sujeitas a abusos específicos $^{33}$. No caso da esterilização forçada, Crenshaw conta sobre a experiência norte-americana, que teve seu auge na década de 1950 e que até os dias atuais continua vitimando mulheres porto-riquenhas e afroamericanas:

Embora as mulheres porto-riquenhas e afro-americanas fossem, de forma desproporcional, as vítimas mais prováveis dessa negação dos direitos reprodutivos por causa da sua raça e classe, o ataque a esse direito humano fundamental raramente tem sido reconhecido como um dos exemplos mais flagrantes de discriminação racial já perpetrados contra povos racializados nos Estados Unidos. Em geral, a esterilização forçada de mulheres em todo o mundo não tem sido tratada como uma questão racial, embora, quando cuidadosamente examinada, se reconheçam aí fatores de risco, como raça, classe e outros, que determinam quais mulheres, mais provavelmente, sofrerão e quais não sofrerão esses abusos ${ }^{34}$.

A afirmativa acima demonstra que a abordagem da discriminação é realizada através da identificação como um problema de gênero. Contudo, a questão racial é totalmente ignorada, não apontando este tipo de

\footnotetext{
${ }^{31}$ Ibid. p. 175

${ }^{32}$ Ibid.

${ }^{33}$ CRENSHAW, Kimberle. Documento para o Encontro de Especialistas em Aspectos da Discriminação Racial relativos ao Gênero. 2002. p.175. Disponível em: http://www.scielo.br/pdf/ref/v10n1/11636.pdf. Acessado em: 22/03/2013.

${ }^{34}$ Ibid. p. 175 .
} 
subordinação. Ocorre que este tipo de invisibilidade vulnerabiliza ainda mais este grupo específico de mulheres, pois não consegue detectar o problema racial dentro da perspectiva de gênero. É importante ressaltar que na subinclusão a diferença torna invisível um conjunto de problemas, enquanto na superinclusão a própria diferença é invisível ${ }^{35}$.

A autora trabalha com as categorias de discriminação de gênero e raça, mostrando que a interseccionalidade entre essas estruturas muitas vezes não é identificada, principalmente nos contextos onde as questões econômicas e socioculturais formam, silenciosamente, um arcabouço desvantajoso, colocando determinadas mulheres em situações de vulnerabilidade.

A discriminação interseccional é particularmente difícil de ser identificada em contextos onde forças econômicas, culturais e sociais silenciosamente moldam o pano de fundo, de forma a colocar as mulheres em uma posição onde acabam sendo afetadas por outros sistemas de subordinação. Por ser tão comum, a ponto de parecer um fato da vida, natural ou pelo menos imutável, esse pano de fundo (estrutural) é, muitas vezes, invisível. O efeito disso é que somente o aspecto mais imediato da discriminação é percebido, enquanto a estrutura que coloca as mulheres na posição de receber tal subordinação permanece obscurecida. Como resultado, a discriminação em questão poderia ser vista simplesmente como sexista (se existir uma estrutura racial como pano de fundo) ou racista (se existir uma estrutura de gênero como pano de fundo). Para apreender a discriminação como um problema interseccional, as dimensões raciais ou de gênero, que são parte da estrutura, teriam de ser colocadas em primeiro plano, como fatores que contribuem para a produção da subordinação ${ }^{36}$.

Por sua vez, Avtar Brah ${ }^{37}$ descreve o conceito de interseccionalidade como um indicador dos efeitos complexos, irredutíveis, diversos e variáveis que decorrem quando múltiplos eixos de diferenciação - econômicos, políticos, culturais, psíquicos, subjetivos e empíricos se cruzam em contextos históricos específicos, o que por sua vez, não permite que essas diferentes dimensões da vida social sejam separadas, de forma discreta ${ }^{38}$, invisibilizando assim o indivíduo. Em seu artigo “Ain't I a Woman?

\footnotetext{
${ }^{35}$ Ibid. p. 176.

${ }^{36}$ Ibid. p. 176.

${ }^{37}$ Aposentou-se recentemente como Professora de Sociologia em Birkbeck - Universidade de Londres, especialista em questões de identidade étnicas, de raça e de gênero.

${ }^{38}$ BRAH, Avtar; PHOENIX, Ann. Ain't I a Woman? Revisiting Interseccionality. Journal of International Women's Studies. Vol. 5 No. 3. Publicado em Maio/2004. p. 76. Disponível em: http://www.bridgew.edu/soas/jiws/may04/phoenix_brah.pdf. Acessado em: 27/03/2013.
} 
Revisiting Interseccionality", Brah identifica que a classe social, por exemplo, com suas interseções de gênero, é simultaneamente subjetiva, estrutural sobre o posicionamento social e as práticas cotidianas ${ }^{39}$. Portanto, ao considerar as interseções de "raça" e gênero com a classe social, o quadro se torna mais complexo e dinâmico ${ }^{40}$, o que dificulta a identificação da profundidade da vulnerabilidade.

Uma questão a ser analisada de forma meticulosa é que as redes de interligação dos diversos tipos de subordinação tendem a criar, em situações históricas específicas, hierarquias de acesso diferenciado a uma variedade de recursos - econômicos, políticos e culturais ${ }^{41}$. Esta compreensão acerca da interseccionalidade das estruturas de opressão abre o campo de visão para compreender a situação das mulheres moradoras de favelas da cidade do Rio de Janeiro que sofrem atualmente com a política de remoção. Apesar do efeito desta medida ser totalmente devastador em suas vidas, essas mulheres são invisíveis aos olhos do Estado e, portanto, vulneráveis à sua ação arbitrária.

A política de remoção, num primeiro momento, identifica apenas a subordinação de classe, tendo em vista que as pessoas residentes em favelas possuem, em sua maioria, uma condição socioeconômica desfavorável. Sendo assim, não são considerados os fatores raça e gênero como agentes vulnerabilizadores. A ação estatal é destinada à população pobre, sem apontar outros indicadores sociais, fato este que desdobra o manto da invisibilidade sobre a demanda afetada pelas remoções.

No próximo item serão abordados os documentos internacionais de proteção ao direito à moradia adequada, os quais já possuem um recorte de gênero, significando uma percepção das instituições e organizações internacionais de direitos humanos acerca da interseccionalidade presente nas questões referentes à moradia.

\footnotetext{
${ }^{39}$ Ibid. p.80.

${ }^{40}$ Ibid. p. 80.

${ }^{41}$ YUVAL-DAVIS, Nira. Intersectionality and Feminist Politics. European Journal of Women's Studies, 2006. p. 199. Disponível em: http://ejw.sagepub.com/content/13/3/193.
} 


\subsection{O Direito à Moradia no Plano Internacional}

Após o término da Segunda Guerra Mundial e do horror trazido pelo holocausto, os países envolvidos neste processo decidiram se unir e criar normas de direitos universais que fossem partilhadas por todos os governos ao redor do mundo. Assim, surge a Organização das Nações Unidas - ONU, em 1945, com o objetivo de manter a paz mundial, reduzir a desigualdade socioeconômica e promover o exercício dos direitos humanos.

O primeiro documento a tratar sobre tais direitos é a Declaração Universal dos Direitos Humanos - DUDH, proclamada em 10 de dezembro de 1948, através da resolução 217-A da Assembleia Geral da ONU. Ela foi elaborada por representantes de diferentes países, com culturas e ordens jurídicas diversas, objetivando a proteção universal desses direitos. A DUDH foi traduzida em mais de 360 idiomas, de modo que se tornou inspiração para as constituições dos países, tornando-se assim o documento mais traduzido do planeta ${ }^{42}$.

O direito à moradia está representado timidamente na DUDH, quando trata sobre a propriedade nos artigos $17 \mathrm{e} 25^{43}$, elencados abaixo:

Artigo XVII

1. Todo ser humano tem direito à propriedade, só ou em sociedade com outros.

2. Ninguém será arbitrariamente privado de sua propriedade.

Artigo XXV

1. Todo ser humano tem direito a um padrão de vida capaz de assegurar-lhe, e a sua família, saúde e bem-estar, inclusive alimentação, vestuário, habitação, cuidados médicos e os serviços sociais indispensáveis, e direito à segurança em caso de desemprego, doença, invalidez, viuvez, velhice ou outros casos de perda dos meios de subsistência em circunstâncias fora de seu controle.

Neste documento é possível perceber a preocupação dos líderes mundiais com a questão da moradia, ilustrada pelo termo "propriedade". Ao estabelecer o direito à propriedade como um direito de todo ser humano e proibir a sua privação arbitrária, denota-se a relevância de tal questão.

\footnotetext{
${ }^{42}$ Disponível em http://www.onu.org.br/documentos/carta-da-onu/. Acessado em 19/03/2013.

${ }^{43}$ Disponível em: http://unicrio.org.br/img/DeclU_D_HumanosVersoInternet.pdf. Acessado em 19/03/2013.
} 
Elencar a habitação como um bem indispensável à vida e bem-estar do indivíduo é configurá-la como um direito humano.

O termo moradia adequada aparece pela primeira vez no Pacto Internacional sobre Direitos Econômicos, Sociais e Culturais, proclamado pela ONU em 16 de Dezembro de 1966. Este documento estabelece as premissas que os Estados partes devem cumprir, reconhecendo que esses direitos decorrem da dignidade inerente à pessoa humana ${ }^{44}$.

\section{ARTIGO 11}

1. Os Estados Partes do presente Pacto reconhecem o direito de toda pessoa a nível de vida adequado para si próprio e sua família, inclusive à alimentação, vestimenta e moradia adequadas, assim como a uma melhoria contínua de suas condições de vida. Os Estados Partes tomarão medidas apropriadas para assegurar a consecução desse direito, reconhecendo, nesse sentido, a importância essencial da cooperação internacional fundada no livre consentimento.

Portanto, o direito à moradia adequada é consagrado neste documento como fundamental para o exercício da cidadania do indivíduo e impõe a responsabilidade da garantia deste direito ao Estado parte. Desta forma, nota-se a relevância do tema no plano internacional, uma vez que, ratificado este pacto, o Estado se compromete a promover melhores condições de vida para os seus habitantes.

Trinta anos após a proclamação da DUDH, em 1978, a ONUHABITAT é estabelecida, após uma reunião em Vancouver para tratar sobre as questões referentes à urbanização e moradia. Com o apoio escasso e um mandato sem foco, este órgão lutou praticamente sozinho entre as organizações multilaterais para prevenir e amenizar os problemas decorrentes do enorme crescimento urbano, destacando-se as cidades dos países em desenvolvimento ${ }^{45}$. A partir de 1997, a ONU-HABITAT foi revitalizada, sendo guiada pela Agenda Habitat $^{46}$ e a Declaração do

\footnotetext{
${ }^{44}$ Disponível em: http://www.unfpa.org.br/Arquivos/pacto_internacional.pdf. Acessado em 20/03/2013.

${ }^{45}$ Disponível em: http://www.unhabitat.org/content.asp?typeid=19\&catid=10\&cid=927. Acessado em 19/03/2013.

${ }^{46}$ Documento lançado pela ONU-HABITAT para promover a moradia adequada a todos. Nele estão descritos os princípios, os compromissos e o plano de ação global para a promoção da moradia adequada pelos países membros.
} 
Milênio $^{47}$, e assim ampliou o seu campo de atuação. Este fato colocou esta organização na agenda de desenvolvimento das Nações Unidas para a redução da pobreza, com uma base estruturada e um conjunto mais relevante, focados nos programas e prioridades sobre esta temática. Sua missão é promover o desenvolvimento social, a sustentabilidade ambiental dos assentamentos humanos e a concretização de moradia adequada para $\operatorname{todos}^{48}$.

Um dos documentos mais importantes é o Comentário Geral $\mathrm{n}^{\circ} 4$ do Comitê sobre os Direitos Econômicos, Sociais e Culturais (Sexta Sessão, 1991) o qual traz considerações importantes acerca da moradia adequada, presente no parágrafo primeiro do artigo 11. Dentre elas, define o conceito, afirmando que a habitação não deve ser interpretada de forma restrita e que o termo "adequada" inclui uma série de outros direitos que estão presentes no conceito de dignidade da pessoa humana:

7. Segundo o ponto de vista do Comitê, o direito à habitação não deveria ser interpretado em um sentido estreito ou restrito que o equipara com, por exemplo, o abrigo provido meramente de um teto sobre a cabeça dos indivíduos ou julga o abrigo exclusivamente como uma mercadoria. Diferentemente, isso deveria ser visto mais propriamente como um direito a viver, onde quer que seja, com segurança, paz e dignidade. Isto é apropriado por, pelo menos, duas razões. Em primeiro lugar, o direito à habitação é integralmente vinculado a outros direitos humanos e a princípios fundamentais sobre os quais a Convenção é baseada. Esta "inerente dignidade da pessoa humana", de que os direitos na Convenção são ditos derivar, exige que o termo "habitação" seja interpretado de forma que leve em conta uma variedade de outras considerações, fundamentalmente que o direito à habitação deveria ser assegurado a todas as pessoas independentemente da renda ou acesso a recursos econômicos. Segundamente, a referência no artigo 11(1) deve ser lida, referindo-se não apenas à habitação, mas à habitação adequada. Como a Comissão sobre Assentamentos Humanos e a Estratégia Global para Habitação para o ano 2000 afirmaram, "habitação adequada significa ... privacidade adequada, espaço adequado, segurança, iluminação e ventilação adequadas, infraestrutura básica adequada e localização adequada em relação ao trabalho e facilidades básicas, tudo a um custo razoável ${ }^{49}$ ".

\footnotetext{
${ }^{47}$ A Declaração do Milênio é um documento histórico para o novo século, lançado na Cúpula do Milênio, evento promovido pela ONU em Setembro de 2000, na cidade de Nova York, no qual os 191 líderes dos Estados-Membros das Nações Unidas, assumiram o compromisso de eliminar a fome e a pobreza extrema de todo o planeta até o ano de 2015, assinando a declaração. Disponível em: http://www.unric.org/html/portuguese/uninfo/DecdoMil.pdf. Acessado em: 20/03/2013.

${ }^{48}$ Disponível em: http://www.unhabitat.org/categories.asp?catid=10. Acessado em: 19/03/2013.

49 Disponível em: http://www.dhnet.org.br/direitos/sos/moradia/trabalhohabitacaopronto.html\#8. Acessado em: 21/03/2013.
} 
O Comentário Geral no 4 sustenta, ainda, que apesar de existirem diversos instrumentos internacionais que tratam das inúmeras dimensões deste direito, o artigo 11 (1), este se estabelece como o mais importante por ser o documento mais abrangente ${ }^{50}$. Isso significa que independente do Estado aderir ou não a outros documentos específicos sobre habitação, ao ratificar este pacto, o Estado parte se responsabiliza pela promoção do direito à moradia adequada. Além disso, identifica que mesmo nos países desenvolvidos, existe uma grande dificuldade em assegurar a habitação adequada aos seus cidadãos:

4. [...] Enquanto os problemas são frequentemente acentuados em alguns países em desenvolvimento, que confrontam restrições quanto aos recursos disponíveis, o Comitê observa que problemas significantes de falta de moradia e habitação inadequada também existem em algumas das sociedades mais desenvolvidas economicamente. As Nações Unidas estimam que há mais de 100 milhões de pessoas sem moradia e mais de 1 bilhão com habitação inadequada em todo o mundo. Não há nenhuma indicação de que este número está decrescendo. Parece claro que nenhum Estado-parte esteja livre de problemas significantes de um tipo ou de outro em relação ao direito à habitação.

Outro importante instrumento relacionado ao pacto é o Comentário Geral $n^{\circ} 7$ do Comitê sobre os Direitos Econômicos, Sociais e Culturais, o qual versa sobre despejos forçados e os reconhece como um grave problema. De acordo com este documento, entende-se por despejos forçados:

[...] a remoção permanente ou temporária, contra a vontade dos indivíduos, famílias e/ou comunidades, das casas e/ou terras que ocupam sem a provisão e o acesso a formas adequadas de proteção jurídica ou outra ${ }^{51}$.

Por conseguinte, esclarece que as transferências forçadas de populações, o deslocamento interno, as realocações forçadas no contexto de um conflito armado, êxodos em massa, movimentos de refugiados, podem ocorrer por diversos motivos, tais quais conflitos armados internacionais, conflitos internos e violência popular ou étnica, ou ainda são causados em nome do desenvolvimento econômico:

Outros casos de desalojamento forçado ocorrem em nome do desenvolvimento. As expulsões podem ser realizadas em conexão com conflitos sobre direitos de

\footnotetext{
${ }^{50} \mathrm{Ibid}$.

${ }^{51}$ Disponível em: http://direitoamoradia.org/wp-content/uploads/2012/05/General-Comment-7.pdf. p. 02. Acessado em: 21/03/2013.
} 
terra, projetos de desenvolvimento e infraestrutura, como a construção de barragens e outros projetos de energia em larga escala, a aquisição de terras associadas a renovação urbana, renovação habitacional, programas de embelezamento da cidade, a limpeza da terra para fins agrícolas, especulação desenfreada da terra, ou a realização de grandes eventos esportivos como os Jogos Olímpicos ${ }^{52}$.

Desde a criação da ONU-HABITAT, vários documentos foram produzidos com o objetivo de proteger o direito à moradia, principalmente dos pobres urbanos do mundo. É interessante perceber que este órgão intensifica seus esforços na promoção deste direito aos casos das minorias, aplicando-o a grupos específicos, tais como mulheres, crianças, moradores de favelas, pessoas sem lar, pessoas com deficiência, desalojados, migrantes e os povos indígenas.

Dada a grande quantidade de instrumentos internacionais, lançados pela ONU-HABITAT, os quais salvaguardam o direito em questão, foram selecionados três documentos de extrema importância para a realização deste trabalho: Forced Evictions Assessment Questionnaire, La Mujer y El Derecho a Una Vivenda Adecuada e The Right to Adequate Housing. Além disso, também será abordada a Cartilha para Mulheres em situação de despejo forçado, a fim de compreender a violação do direito à moradia das mulheres moradoras das favelas cariocas.

Segundo "O Direito à Moradia Adequada" (The Right to Adequate Housing), manual lançado pela ONU-Habitat e pelo Alto Comissariado das Nações Unidas sobre Direitos Humanos (OHCHR), o conceito de moradia adequada inclui:

[...] a garantia de um lugar para morar sem ameaça de remoção, o acesso a educação, saúde, lazer, transporte, energia elétrica, água potável e esgoto, coleta de lixo, áreas verdes e um meio ambiente saudável; proteção efetiva contra frio, calor, chuva, vento, incêndio, inundação, sem riscos de desmoronamento ou outras ameaças à saúde e à vida; acesso aos meios de subsistência, inclusive acesso à terra e a trabalho; uso de materiais, estruturas e organização espacial de acordo com a cultura dos moradores; prioridade às necessidades de grupos específicos, como as mulheres e grupos vulneráveis como crianças, idosos e

\footnotetext{
${ }^{52}$ Id. p.2.
} 
deficientes; acesso independente da renda ou da capacidade de pagar do morador $^{53}$.

Este detalhamento busca, na verdade, afastar a ideia de que a moradia adequada se resume a um teto com quatro paredes. Não se trata apenas do imóvel, mas sim de toda a estrutura do qual faz parte, tanto interna quanto externa. Sendo assim, estão incluídos nesta descrição os conceitos de segurança da posse, disponibilidade de serviços, infraestrutura e equipamentos públicos, habitabilidade, localização adequada, adequação cultural, custo acessível, o princípio da não discriminação e a priorização de grupos vulneráveis ${ }^{54}$. Estes sete elementos compõem o que se compreende por moradia adequada.

$\mathrm{O}$ manual em questão prevê também os direitos pertinentes às situações de remoção forçada, identificadas como um gravíssimo problema na maioria das nações. Logo, são abarcados neste rol a proteção contra os despejos forçados e contra a destruição ou demolição arbitrária de casas; o direito de ser livre das possíveis interferências nos lares, privacidade e família; o direito de escolher a própria residência, de determinar onde se vive e da liberdade de ir e vir ${ }^{55}$.

Quanto à segurança da posse, esta é estabelecida como um direito fundamental, exigindo acesso igual e não discriminatório à moradia adequada. A restituição da moradia, terra ou propriedade, por parte do Estado e a participação nas decisões relacionadas com a habitação a nível nacional e local, ou seja, deve haver manifestação de vontade por parte da comunidade envolvida, também são elementos constituintes do direito à $\operatorname{posse}^{56}$.

\footnotetext{
${ }^{53}$ Disponível em: http://direitoamoradia.org/wpcontent/uploads/2012/01/GUIA_REMOCOES_portugues_20119.pdf. p. 05. Acessado em: 25/03/2013.

${ }_{54}$ Disponível em: http://direitoamoradia.org/wp-content/uploads/2012/01/guia-mulheres-PT.pdf. Acessado em: 25/03/2013.

${ }^{55}$ The Right To Adequate Housing. ONU-HABITAT. Disponível em: http://www.ohchr.org/Documents/Publications/FS21_rev_1_Housing_en.pdf. p. 03. Acessado em: 23/03/2013.

${ }^{56}$ Ibid.
} 
Outro ponto relevante abordado pelo manual é a aplicação do princípio da não discriminação na habitação. A ONU-HABITAT entende que a discriminação pode ocorrer de forma ativa, através de políticas excludentes, ou de forma omissa, quando não se manifesta diante das ações discriminatórias realizadas por agentes privados. Sendo assim, o Estado tem a obrigação de promover o princípio da não discriminação, no que tange a moradia, seja por meio de políticas públicas ou na inibição e proibição de atos discriminatórios privados.

\begin{abstract}
Na habitação, a discriminação pode assumir a forma de leis, políticas ou medidas discriminatórias, a regulamentação de zoneamento, ou desenvolvimento de política excludente; exclusão de benefícios habitacionais; negação de segurança da posse, a falta de acesso ao crédito; participação limitada na tomada de decisões, ou falta de proteção contra práticas discriminatórias realizadas por agentes privados ${ }^{57}$.
\end{abstract}

Há uma questão muito interessante presente neste instrumento e de grande importância: a percepção da questão de gênero dentro do direito à moradia. Ele identifica que as mulheres estão sujeitas a muitos tipos de discriminação no que tange à habitação, tais como pobreza, idade, classe social, orientação sexual e etnia ${ }^{58}$, e reconhece, ainda, que existe uma grande quantidade de mulheres vivendo em áreas precárias.

Além disso, o documento destaca o fato de que em inúmeros casos a posse (ou propriedade) é registrada em nome dos homens, afetando assim a sua segurança. Assim, reforça a importância da moradia para as vítimas de violência doméstica, tendo em vista que, quando o registro é realizado em nome dos homens, as mulheres muitas vezes permanecem na residência, sofrendo agressões, porque não têm um local seguro para morar com seus filhos, o que as torna mais vulneráveis. Outrossim, ressalta ainda o estresse emocional causado antes, durante e depois de um despejo forçado, devido aos laços estreitos com a casa, seu papel de cuidadora e provedora da família. Em muitos casos, no processo de remoção, as mulheres são agredidas verbal e fisicamente, sendo vítimas até mesmo de estupros ${ }^{59}$,

\footnotetext{
${ }^{57}$ Ibid. p. 10 .

${ }^{58}$ Ibid. p. 17.

${ }^{59}$ Idem. p. 18.
} 
além de serem realocadas com suas famílias em espaços distantes do local de origem, os quais possuem infraestrutura precária, dificultando assim sua nova condição de vida.

Isso significa que as mulheres vivem diferentes dramas no setor habitacional, os quais estão intrinsecamente relacionados com a posição e o papel que desempenham na sociedade. Assim, é possível compreender a partir desta observação o grande valor que a moradia possui no empoderamento ${ }^{60}$ das mulheres. O empoderamento é compreendido como a representação igualitária feminina na sociedade, tanto no processo das tomadas de decisões na esfera pública, sendo reconhecidas e valorizadas como mulheres, quanto conquistando sua autonomia em âmbito privado. Desta forma, a segurança quanto à posse da moradia implica diretamente no empoderamento da mulher, posto que terá mais liberdade para tomar decisões, enquanto a remoção ou despejo forçado contribui para seu desempoderamento, pois restringe seu campo de atuação, dada a insegurança quanto ao local de moradia.

Em 2012, foi publicado o documento "Mulheres e o Direito à Moradia Adequada da Mulher" (La Mujer y El Derecho a Uma Vivenda Adecuada), pelo Alto Comissariado de Direitos Humanos das Nações Unidas. Consiste num manual, com três capítulos, que trata sobre os direitos da mulher referentes à habitação. Neste são abordadas as leis protetivas internacionais de direitos humanos que regem este direito específico, os instrumentos e iniciativas regionais, a discriminação contra a mulher nas áreas de habitação, terras e propriedades, e questões específicas

\footnotetext{
${ }^{60} \mathrm{O}$ empoderamento implica, pois, no reconhecimento das restrições sociais a que a categoria está submetida e da necessidade de reversão dessa situação, por meio de mudanças em um contexto amplo/público (inserção em cargos de poder/decisão, educação não sexista e serviços de saúde adequados) e também em contextos mais específicos, ou individuais (aumento de autoestima e autonomia, reorganização do trabalho doméstico, etc). CORTEZ, Mirian Béccheri e SOUZA, Lídio de. Mulheres (in)subordinadas: o empoderamento feminino e suas repercussões nas ocorrências de violência conjugal. Psic.: Teor. e Pesq. [online]. 2008, vol.24, n.2, p. 171-180. ISSN 0102-3772. Disponível em: http://www.scielo.br/pdf/ptp/v24n2/05.pdf. Acessado em 04/04/2013.
} 
acerca da sucessão, despejos forçados, violência doméstica, condições inadequadas de moradia, AIDS, desastres naturais, mudanças climáticas e crises financeiras.

Este manual traz indicadores de extrema importância sobre a questão de gênero dentro da área de habitação, como por exemplo, o fato de a população feminina constituir $70 \%$ dos pobres do mundo inteiro ${ }^{61}$. Esse dado é importante porque indica que essas mulheres vivem em locais de moradia não adequados, conforme o conceito criado pela ONU. Outro fator importante apontado neste documento é a discriminação intersecional no âmbito da habitação:

"Numerosos testemunhos das pesquisas regionais mostram que a discriminação interseccional constitui um obstáculo fundamental para a realização do direito à moradia adequada, porque muitas vezes leva as mulheres a viver em habitações inadequadas ou em comunidades segregadas, sem serviços básicos, como água potável, saneamento ou eletricidade. Mulheres vivendo na extrema pobreza ou desempregadas, as mulheres indígenas e pertencentes a tribos, viúvas, divorciadas ou separadas, chefes de família, meninas, mulheres idosas, mulheres com deficiência, trabalhadoras domésticas, migrantes, lésbicas, bissexuais e transgêneros são particularmente vulneráveis ${ }^{62 \%}$.

“A Comissão do Pacto Econômico, Social e Cultural destacou a importância de se levar em conta a discriminação intersecional no seu Comentário Geral no 16 (2005): Muitas mulheres sofrem diversas formas de discriminação com base no sexo, combinado com fatores como raça, cor, língua, religião, opinião política ou outra, origem nacional ou social, posição econômica, nascimento ou outros fatores como idade, etnia, presença de deficiência, estado civil, a condição de refugiado ou imigrante, o que agrava a desvantagem $\left(\mathrm{n}^{\circ} 5\right)^{63,}$.

A discriminação intersecional, já conceituada anteriormente, é reconhecida pela ONU-HABITAT como um impedimento à conquista do direito à moradia das mulheres. Portanto, os Estados partes devem assegurar o princípio da não discriminação dentro das questões habitacionais, a fim de que este direito seja respeitado.

Além da discriminação intersecional, este documento alerta também sobre a importância da segurança da posse para as mulheres:

A falta de segurança da posse pode levar a consequências graves para as mulheres. Sem controle ou sem a posse da moradia, terra e propriedade, as

\footnotetext{
${ }^{61}$ Mujeres y El derecho a Uma Vivenda Adecuada. Disponível em: http://direitoamoradia.org/wpcontent/uploads/2013/01/OHCHR_Mujeres-y-el-derecho-a-una-vivienda-adecuada.pdf. p. 39.

${ }^{62}$ Ibid. p. 40-41.

${ }^{63}$ Ibid. p. 40-41.
} 
mulheres se encontram com escassa autonomia pessoal ou econômica, portanto, são mais suscetíveis a abusos e violência na família, comunidade e sociedade em geral. Quando o acesso das mulheres à moradia, terra ou propriedade depende de um terceiro (marido, irmão, pai ou outro parente do sexo masculino), as mulheres são vulneráveis à perda familiar, pobreza e indigência quando termina o relacionamento com o homem ${ }^{64}$.

Mais uma vez a segurança da posse é retomada como um fator, necessário para o empoderamento das mulheres, que o Estado deve prestar atenção ao criar e promulgar suas leis, para que esta demanda não se torne invisível nos assuntos ligados à moradia. A existência de uma legislação neutra não considera as circunstâncias específicas das mulheres e do mesmo modo, não reconhece a discriminação baseada em fatores estruturais e históricos, o que por sua vez impede a participação feminina nos processos de tomadas de decisão ${ }^{65}$.

A discriminação das mulheres pode ser causada pela discriminação contida na lei, a existência de leis e neutro não levam em conta as circunstâncias específicas das mulheres, as prevalência de leis e práticas costumeiras, as ações administração pública e da justiça parcial, a falta de acesso a recursos e informações e participação nos processos de tomada de decisões e falta de consciência dos direitos. Esta discriminação é baseada em fatores estruturais e históricas. Não só é um discriminação intolerável que viola as normas de direitos humanos mas, como um resultado disso, as mulheres são vítimas de enorme violações do direito à moradia adequada e outros direitos humanos fundamentais.

Este documento conclui que o Estado deve rever as suas leis e políticas para identificar os casos em que as leis neutras perpetuam a situação de desigualdade em relação ao gênero, além de eliminar as leis que possuam teor discriminatório neste campo. Outro dever do Estado é estabelecer a participação de mulheres no desenvolvimento, na implementação e monitoramento de leis, políticas e programas, incluindo a garantia de que as mulheres pertencentes a grupos em situação de vulnerabilidade e/ou marginalizados tenham acesso às ações específicas ${ }^{66}$. Os esforços governamentais devem ser concretizados, referindo-se às suas obrigações internacionais e implementando as recomendações dos órgãos

\footnotetext{
${ }^{64}$ Ibid. p. 42.

65 Ibid. p. 43-44.

${ }^{66}$ Ibid. p. 100.
} 
de direitos humanos, além de garantir que as mulheres conheçam seus direitos e os meios apropriados para exigi-los.

O "Questionário de Avaliação dos Despejos Forçados" (Forced Evictions Assessment Questionnaire) ${ }^{67}$ é um instrumento criado, pela ONUHABITAT, para orientar e lidar com as situações de despejos forçados, através da contextualização dos acontecimentos, da avaliação do tipo de violações de direitos humanos que estão previstas em curso e oferecer conselhos práticos relacionados à questão, além de contribuir para o monitoramento e informações sobre o tema.

O questionário difunde conhecimentos, sobre a legislação internacional, relativos à moradia e busca identificar claramente as vítimas, de acordo com o grupo ou comunidade que pertencem, ou mesmo se o fato ocorreu de forma individual. Não obstante, investiga a composição e as características do grupo afetado conforme o gênero, etnia, idade, seu pertencimento a uma minoria, se são pessoas com deficiência, migrantes, sem-teto, etc ${ }^{68}$. Identifica também os representantes da comunidade, considerando a dimensão de gênero, avalia se há tensões, rivalidades ou outras dinâmicas dentro das populações afetadas ou entre os seus líderes.

Segundo este documento é importante considerar se a população afetada enfrenta a discriminação em termos de acesso à justiça, aos serviços sociais, tanto no que tange à legislação quanto à execução das políticas públicas e identificar se há outras violações de direitos humanos enfrentadas pela população ${ }^{69}$. E, por sua vez, é preciso mapear os atores envolvidos direta ou indiretamente relacionados com a questão, analisando as perspectivas, a fim de descobrir as formas mais eficientes para intervir com sucesso numa situação de remoção.

Todas as perguntas deste questionário são baseadas nos sete conceitos que constituem o conceito de moradia adequada, as quais se

\footnotetext{
${ }^{67}$ Forced Evictions Questionnaire. ONU-HABITAT. Disponível em: http://www2.ohchr.org/english/issues/escr/docs/ForcedEvictionsAssessmentQuestionnaire.pdf. Acessado em 05/05/2013.

${ }^{68}$ Ibid. p. 03.

${ }^{69}$ Ibid. p.03.
} 
dividem em três blocos: antes, durante e após as remoções. Ademais, há um questionário final sobre as soluções para este problema, buscando novas alternativas direcionadas à sua resolução. Contudo, existe outro questionário, criado pela ONU-HABITAT, direcionado à situação de moradia das mulheres: "Questionário sobre a Moradia Adequada e a Mulher (Cuestionario sobre La Vivenda Adecuada y la Mujer). Este pretende "solicitar informações aos Estados, autoridades locais, sociedade civil e outras partes interessadas, com vista à elaboração de um estudo sobre o tema da mulher e habitação" $"$.

Todos esses mecanismos citados anteriormente demonstram os esforços da ONU-HABITAT no tratamento da problemática de moradia para a população feminina, exercendo o importante papel de reconhecer a vulnerabilidade desta demanda, partindo da discriminação intersecional, e identificando os impactos negativos causados pela remoção, principalmente no que diz respeito ao desempoderamento das mulheres.

Considerando o arcabouço da legislação internacional protetiva de direitos humanos para o tema da moradia, serão analisados, no próximo item, os mecanismos internos de proteção ao direito à moradia no Brasil, destacando se eles obedecem às normas dos tratados internacionais e se estão em sintonia com a análise intersecional, concebendo as dimensões de gênero, classe, raça ou etnia e local de moradia.

\section{3. $O$ Direito à Moradia no Brasil}

Apesar das violações do direito à moradia ocorrerem, de forma contínua e indecorosa, em âmbito nacional, existe uma ampla legislação que o protege desde a esfera constitucional, passando pelas leis federais, e se estendendo até o distrito municipal. Adiante serão apresentados os principais instrumentos nacionais que versam sobre o tema.

\footnotetext{
${ }^{70}$ Cuestionario Sobre La Vivienda Adecuada y La Mujer. p.01. Disponível em: http://direitoamoradia.org/?p=6563\&lang=es. Acessado em: 07/05/2012.
} 
O direito à moradia é estabelecido na Constituição Federal a partir da Emenda Constitucional $N^{\circ} 26 / 2000$, sendo inserido no art. $6^{\circ}$, o rol dos direitos sociais, ou seja, aqueles considerados imprescindíveis para o exercício pleno da cidadania. Segundo José Afonso da Silva, a moradia já estava consagrada na Carta Magna antes mesmo do advento da EC26/2000 ${ }^{71}$, pois de acordo com o art.23, inciso IX, é da competência dos Estados, Municípios, Distrito Federal e União, "promover programas de construção de moradias e a melhoria das condições habitacionais e de saneamento".

A garantia constitucional deste direito amplia a sua compreensão, pois ao restar configurado como um direito social, inclui princípios e valores declarados na Constituição, tais como a dignidade da pessoa humana e a cidadania, dispostas em seu art. $1^{\circ}$. José Afonso da Silva alerta para o fato de que a moradia não deve ser interpretada como apenas a ocupação de uma habitação, porquanto deve ser compreendida dentro das dimensões dos princípios e valores defendidos pela Carta Constitucional.

O conteúdo do direito à moradia envolve não só a faculdade de ocupar uma
habitação. Exige-se que seja uma habitação de dimensões adequadas, em
condições de higiene e conforto e que preserve a intimidade pessoal e à
privacidade familiar, como se prevê na Constituição portuguesa (art. 65). Em
suma, que seja uma habitação digna e adequada, como quer a Constituição
espanhola (art. 47). Nem se pense que estamos aqui reivindicando a apliçãão
dessas constituições ao sistema. Não é isso. É que a compreensão do direito à
moradia, como direito social, agora inserido expressamente em nossa
Constituição, encontra normas e princípios que exigem que ele tenha aquelas
dimensões. Se ela prevê como um princípio fundamental, a dignidade da pessoa
humana (art. $1^{\circ}$, III), assim como o direito à intimidade e à privacidade (art. $5^{\circ}$,
X), e que a casa é um asilo inviolável (art. $\left.5^{\circ}, X I\right)$, então tudo isso envolve,
necessariamente, o direito à moradia. Não fosse assim seria um direito
empobrecido ${ }^{72}$.

Além de a moradia ser amparada pelas diretrizes constitucionais, está também incluída nos objetivos fundamentais descritos no art. $3^{\circ}$ da $\mathrm{CF} / 88$. Ao tratar da erradicação da pobreza e da marginalização e reduzir as desigualdades sociais e regionais (inciso III) e do mesmo modo se dedicar à

\footnotetext{
${ }^{71}$ SILVA, José A. da. Curso de Direito Constitucional Positivo. $29^{a}$ Edição. Ed. Malheiros. São Paulo. 2007. p. 314.

${ }^{72}$ Ibid. p. 314.
} 
promoção do bem de todos, sem preconceito de origem, raça, sexo, cor, idade e quaisquer outras formas de discriminação (inciso IV), a Constituição alcança por sua vez o direito à moradia, refletindo os princípios da isonomia e da não discriminação.

É importante ressaltar, que além de ser configurado como um direito constitucional social, o direito à moradia está elencado como direito humano, necessário ao desenvolvimento dos cidadãos e que, portanto, deve ser defendido e garantido pelos países que ratificaram os tratados de direitos humanos ao longo dos anos, como é o caso do Brasil. Desde a promulgação da Emenda Constitucional no 45/2004, a qual acrescentou o parágrafo terceiro no artigo quinto, as normas de direitos humanos aprovadas pelo Congresso, conforme o procedimento exigido, equivalem às emendas constitucionais.

Art. $5^{\circ}, \S^{\circ}$ - Os tratados e convenções internacionais sobre direitos humanos que forem aprovados, em cada Casa do Congresso Nacional, em dois turnos, por três quintos dos votos dos respectivos membros, serão equivalentes às emendas constitucionais.

Esta inovação do ordenamento jurídico brasileiro confirma o compromisso internacional firmado, mediante a ratificação dos tratados e convenções de direitos humanos, a fim de conferir maior efetivação à sua implementação. Demonstra, ainda, a responsabilidade do Brasil no processo de prevenção contra as violações de quaisquer direitos humanos, como por exemplo, o direito à moradia.

Considerando tais fatores, o governo brasileiro tenta, através de leis, programas e políticas públicas, zelar pelo direito à moradia. Entretanto, a real efetivação e conquista deste direito pela população pobre ainda seja precária, tendo em vista a quantidade de pessoas que residem em moradias concebidas como não adequadas, segundo os padrões exigidos pela ONU.

Um exemplo do esforço empreendido pelo Estado, no sentido de garantir a moradia adequada está contido na Política Nacional de Habitação. A política foi criada pelo Ministério das Cidades, do Governo Federal, no ano de 2004. Esse instrumento objetiva criar caminhos para desenvolver os 
projetos habitacionais do país, enfatizando as condições de moradia da população carente:

[...] a Política Nacional de Habitação visa promover as condições de acesso à moradia digna a todos os segmentos da população, especialmente o de baixa renda, contribuindo, assim, para a inclusão social.

Nessa perspectiva, a Política Nacional de Habitação tem como componentes principais: a Integração Urbana de Assentamentos Precários, a urbanização, regularização fundiária e inserção de assentamentos precários, a provisão da habitação e a integração da política de habitação à política de desenvolvimento urbano, que definem as linhas mestras de sua atuação.

A Política Nacional de Habitação conta com um conjunto de instrumentos a serem criados, pelos quais se viabilizará a sua implementação. São eles: o Sistema Nacional de Habitação (SNH), o Desenvolvimento Institucional, o Sistema de Informação, Avaliação e Monitoramento da Habitação, e o Plano Nacional de Habitação ${ }^{73}$.

O documento em questão apresenta alternativas diversas para solucionar os problemas de moradia, superando o déficit habitacional brasileiro. Porém, o que demanda bastante atenção é o fato dessas ações propostas pelo governo serem realizadas em acordo com a comunidade ou moradores individuais envolvidos, através de mutirões para construção de casas ou mesmo pela capacitação de lideranças comunitárias e órgãos de assessoria técnica. Além da participação civil daqueles envolvidos no processo, o texto sugere ainda que haja investimento nas pesquisas sobre habitação e moradia para a população de baixa renda ${ }^{74}$. Desta maneira, percebe-se que o governo valorizou, no momento da criação do documento, a participação popular nas políticas habitacionais. Contudo, raramente, a opinião do morador ou dos órgãos de assessoria é considerada, principalmente no que se refere às remoções.

Outro importantíssimo instrumento de regulação do direito à moradia é a Lei 10.257/2001, conhecida como o Estatuto da Cidade ${ }^{75}$. No seu artigo

\footnotetext{
73 Política Nacional de Habitação. p.29. Ministério das Cidades - Governo Federal. 2004. Disponível http://www.cidades.gov.br/images/stories/ArquivosSNH/ArquivosPDF/4PoliticaNacionalHabitaca o.pdf. Acessado 22/04/2013.

${ }^{74}$ Ibid. p. 33.

75 O Estatuto da Cidade é a lei federal brasileira que regulamenta os artigos 182 e 183 da Constituição Federal de 1988. O artigo 182 dispõe que a política urbana é responsabilidade do Município e deve garantir as funções sociais da cidade e o desenvolvimento dos cidadãos.
} 
segundo, incisos I e II, são garantidas as funções sociais da cidade e da propriedade urbana, além de garantir a gestão democrática através da participação popular:

Art. $2^{\circ}$ - A política urbana tem por objetivo ordenar o pleno desenvolvimento das funções sociais da cidade e da propriedade urbana, mediante as seguintes diretrizes gerais:

I - garantia do direito a cidades sustentáveis, entendido como o direito à terra urbana, à moradia, ao saneamento ambiental, à infraestrutura urbana, ao transporte e aos serviços públicos, ao trabalho e ao lazer, para as presentes e futuras gerações;

II - gestão democrática por meio da participação da população e de associações representativas dos vários segmentos da comunidade na formulação, execução e acompanhamento de planos, programas e projetos de desenvolvimento urbano; $[\ldots]$

Sendo assim, esta lei federal, vigente em todo o território brasileiro, consagra a função social da propriedade e a gestão democrática das cidades, indicando que Estados e Municípios devem seguir essas diretrizes em seus planos diretores, coadunando-se assim com os princípios difundidos e garantidos pela Constituição Federal e pelas normas internacionais de direitos humanos.

Além disso, tendo em vista a perspectiva da interseccionalidade anteriormente apresentada, destacamos também a políticas de promoção da igualdade de gênero e de combate ao racismo e às desigualdades raciais no Brasil. Nesse sentido, o Plano Nacional de Políticas para as Mulheres ${ }^{76}$, da

Estabelece, ainda, que o Plano Diretor Municipal é o instrumento básico do ordenamento territorial urbano, devendo definir qual deve ser o uso e as características de ocupação de cada porção do território municipal, fazendo com que todos os imóveis cumpram sua função social. Estatuto da Cidade Comentado. p.91. Ministério das Cidades - Governo Federal. 2010. Disponível em: http://www.cidades.gov.br/images/stories/ArquivosSNPU/Biblioteca/PlanelamentoUrbano/Estatut oComentado_Portugues.pdf. Acessado em: 28/04/2013.

76 O PNPM tem 199 ações, distribuídas em 26 prioridades, que foram definidas a partir dos debates estabelecidos na I Conferência Nacional de Políticas para as Mulheres. Elas foram organizadas por um Grupo de Trabalho, coordenado por esta Secretaria e composto por representantes dos ministérios da Saúde, Educação, Trabalho e Emprego, Justiça, Desenvolvimento Agrário, Desenvolvimento Social e Combate à Fome, Planejamento, Orçamento e Gestão, Minas e Energia e Secretaria Especial de Políticas da Promoção da Igualdade Racial (SEPPIR), Conselho Nacional dos Direitos da Mulher (CNDM) e de representantes das esferas governamentais estadual - representados pelo Acre - e municipal - representada por Campinas/SP. As ações do Plano foram traçadas a partir de 4 linhas de atuação, consideradas como as mais importantes e urgentes para garantir, de fato, o direito a uma vida melhor e mais digna para todas as mulheres. São elas: promover a autonomia econômica e financeira das mulheres; promover a equidade de gênero, raça e etnia nas relações de trabalho; promover 
Secretaria Especial de Políticas para as Mulheres - SPM, prevê como uma das prioridades "ampliar o exercício da cidadania das mulheres e do acesso a terra e à moradia"7,", no capítulo denominado como "Autonomia, Igualdade no Mundo do trabalho e Cidadania". Desta maneira, identifica que a moradia é condição fundamental para a autonomia feminina. É importante recordar que o programa de habitação, do governo federal, "Minha Casa, Minha Vida" dá preferência para o registro do imóvel em nome da mulher, chefe de família ${ }^{78}$, colaborando assim para o seu empoderamento.

No que se refere às políticas de combate ao racismo e às desigualdades raciais o Plano Nacional de Promoção da Igualdade Racial $\left(\right.$ PLANAPIR) ${ }^{79}$, instituído pelo Decreto $\mathrm{n}^{\mathrm{o}}$ 6.872, de junho de 2009, e seguindo as diretrizes traçadas na Política Nacional de Promoção da Igualdade Racial (PNPIR) ${ }^{80}$, afirma no eixo 11:

\section{Eixo 11: Infraestrutura}

I - assegurar o acesso da população negra, indígena, quilombola e cigana, urbanas ou rurais, aos programas de política habitacional;

II - estabelecer política de promoção da igualdade racial nos programas de financiamento de habitação, de interesse social, sob gestão do Governo Federal;

III - fornecer orientação técnica aos Municípios para que incluam no seu planejamento territorial áreas urbanas e rurais, os territórios quilombolas e as áreas de terreiro destinadas ao culto da religião de matriz africana;

IV-promover eletrificação nas áreas habitadas pelas comunidades negras, quilombolas e indígenas do meio rural; e

políticas de ações afirmativas que reafirmem a condição das mulheres como sujeitos sociais e políticos; ampliar a inclusão das mulheres na reforma agrária e na agricultura familiar; promover o direito à vida na cidade com qualidade e o acesso a bens e serviços. Plano Nacional de Políticas para as Mulheres. Secretaria Especial de Políticas para Mulheres. Brasília. 2005. p.13.Disponívelem:http://bvsms.saude.gov.br/bvs/publicacoes/pnpm_compacta.pdf. Acessado em 29/04/2013.

${ }^{77}$ Ibid. p. 15.

${ }^{78}$ Disponível em: http://www.brasil.gov.br/secoes/mulher/atuacao-feminina/retrato-das-brasileiras. Acessado em: 25/04/2013.

${ }^{79}$ Disponível em: http://www.planalto.gov.br/ccivil_03/_Ato2007-2010/2009/Decreto/D6872.htm. Acessado em: 25/04/2013.

${ }^{80} \mathrm{O}$ objetivo central da Política Nacional de Promoção da Igualdade Racial consiste em reduzir as desigualdades raciais no Brasil, com ênfase na população negra. Trata-se, por evidente, de um objetivo cuja realização impôs a definição de ações exequíveis a longo, médio e curto prazos, além do reconhecimento das demandas mais imediatas, bem como das áreas de atuação prioritária: A afirmação do caráter pluriétnico da sociedade brasileira; Terras para os quilombolas; A criminalização do racismo; Ação afirmativa; Articulação temática de raça e gênero. Política Nacional de Promoção da Igualdade Racial (PNPIR). Secretaria Especial de Políticas de Promoção da Igualdade Racial (SEPPIR). Brasília. 2003. Disponível em: http://www.planalto.gov.br/seppir/pnpir/pnpir_programa/objetivo.htm. Acessado em: 29/04/2013. 
$\mathrm{V}$ - promover o saneamento básico nas áreas habitadas pelas comunidades negras e quilombolas.

A Secretaria de Políticas de Promoção da Igualdade Racial (SEPPIR) reconhece a moradia como uma questão imprescindível para a redução das desigualdades raciais, e inclusive assegura a igualdade racial nos programas habitacionais do Governo Federal, tanto nas áreas urbanas, quanto nas rurais. Desta maneira, incorpora os elementos constituintes do conceito de moradia adequada, ao prever saneamento básico e eletrificação das áreas habitadas pelas comunidades negras.

Por fim, ressalta-se que a Lei 12.288/2010, que instituiu o Estatuto da Igualdade Racial ${ }^{81}$, dispõe, no Capítulo IV - Do Acesso à Terra e à Moradia Adequada, nos arts. 35 a 37, que:

\section{Seção II - Da Moradia}

Art. 35. O poder público garantirá a implementação de políticas públicas para assegurar o direito à moradia adequada da população negra que vive em favelas, cortiços, áreas urbanas subutilizadas, degradadas ou em processo de degradação, a fim de reintegrá-las à dinâmica urbana e promover melhorias no ambiente e na qualidade de vida.

Parágrafo único. O direito à moradia adequada, para os efeitos desta Lei, inclui não apenas o provimento habitacional, mas também a garantia da infraestrutura urbana e dos equipamentos comunitários associados à função habitacional, bem como a assistência técnica e jurídica para a construção, a reforma ou a regularização fundiária da habitação em área urbana.

Art. 36. Os programas, projetos e outras ações governamentais realizadas no âmbito do Sistema Nacional de Habitação de Interesse Social (SNHIS), regulado pela Lei $\mathrm{n}^{\mathrm{O}} 11.124$, de 16 de junho de 2005 , devem considerar as peculiaridades sociais, econômicas e culturais da população negra.

Parágrafo único. Os Estados, o Distrito Federal e os Municípios estimularão e facilitarão a participação de organizações e movimentos representativos da população negra na composição dos conselhos constituídos para fins de aplicação do Fundo Nacional de Habitação de Interesse Social (FNHIS).

Art. 37. Os agentes financeiros, públicos ou privados, promoverão ações para viabilizar o acesso da população negra aos financiamentos habitacionais ${ }^{82}$.

${ }^{81}$ O Estatuto da Igualdade Racial é destinado a garantir à população negra a efetivação da igualdade de oportunidades, a defesa dos direitos étnicos individuais, coletivos e difusos e o combate à discriminação e às demais formas de intolerância étnica. Disponível em: http://www.planalto.gov.br/ccivil_03/_Ato2007-2010/2010/Lei/L12288.htm. Acessado em: $29 / 04 / 2013$.

${ }^{82}$ Disponível em: http://www.planalto.gov.br/ccivil_03/_Ato2007-2010/2010/Lei/L12288.htm. Acessado em: 29/04/2013. 
O Estatuto inova ao garantir o direito à moradia da população negra residente nas favelas e a sua inclusão na dinâmica urbana, além de assegurar que as habitações estejam inseridas numa infraestrutura adequada. Outro ponto importante desta seção é a garantia da assistência técnica e jurídica para questões referentes à construção, reforma e regularização fundiária, o que contribui para o acesso à justiça da população negra moradora de favela. É o documento que mais se aproxima da justiça social e racial em termos de moradia, responsabilizando, ainda, os Estados, os Municípios e o Distrito Federal pela implementação de soluções habitacionais, que por sua vez devem facilitar o acesso do povo negro aos financiamentos realizados pelo Governo Federal e pela iniciativa privada.

Nesse sentido, ao refletirmos sobre os eventos arbitrários ocorridos na cidade do Rio de Janeiro, é de extrema importância que seja investigado o que a legislação local discorre sobre o assunto. Dessa forma, abordaremos primeiramente a Constituição Estadual e, posteriormente, a Lei Orgânica do Município do Rio de Janeiro.

Promulgada em 05 de Outubro de 1989, a Constituição do Estado do Rio de Janeiro trata sobre a questão habitacional, nos artigos abaixo relacionados:

Art. 229 - A política urbana a ser formulada pelos Municípios e, onde couber, pelo Estado, atenderá ao pleno desenvolvimento das funções sociais da cidade com vistas à garantia e melhoria da qualidade de vida de seus habitantes.

$\S 1^{\circ}$ - As funções sociais da cidade são compreendidas como o direito de todo o cidadão de acesso à moradia, transporte público, saneamento básico, energia elétrica, gás canalizado, abastecimento, iluminação pública, saúde, educação, cultura, creche, lazer, água potável, coleta de lixo, drenagem das vias de circulação, contenção de encostas, segurança e preservação do patrimônio ambiental e cultural.

$\S 2^{\circ}-\mathrm{O}$ exercício do direito de propriedade atenderá à função social quando condicionado às funções sociais da cidade e às exigências do plano diretor.

$\S 3^{\circ}$ - Aos Municípios, nas leis orgânicas e nos planos diretores, caberá submeter o direito de construir aos princípios previstos neste artigo.

[...]

Art. 234 - No estabelecimento de diretrizes e normas relativas ao desenvolvimento urbano, o Estado e os Municípios assegurarão:

I - urbanização, regularização fundiária e titulação das áreas faveladas e de baixa renda, sem remoção dos moradores, salvo quando as condições físicas da área imponham risco à vida de seus habitantes; 
Art. 265 - Os projetos governamentais da administração direta ou indireta, que exijam a remoção involuntária de contingente da população, deverão cumprir, dentre outras, as seguintes exigências:

I - pagamento prévio e em dinheiro de indenização pela desapropriação, bem como dos custos de mudança e reinstalação, inclusive, neste caso, para os não proprietários, nas áreas vizinhas às do projeto, de residências, atividades produtivas e equipamentos sociais.

II - implantação, anterior à remoção, de programas socioeconômicos que permitam às populações atingidas restabelecerem seu sistema produtivo garantindo sua qualidade de vida;

III - implantação prévia de programas de defesa ambiental que reduzam ao mínimo os impactos do empreendimento sobre a fauna, a flora e as riquezas naturais e arqueológicas ${ }^{83}$.

$\mathrm{O}$ art. 229 e parágrafos seguintes reforçam, mais uma vez, que a política urbana deve se fundamentar na função social da propriedade e incorporar os elementos fundamentais da moradia adequada exigidos pela ONU, além de condicionar os municípios a seguirem tais preceitos na criação de suas leis orgânicas e planos diretores. Já no art. 234, inciso primeiro, ocorre a proibição da remoção de áreas favelizadas, a não ser que haja risco de morte para os moradores.

Por conseguinte, o art. 265 cuida das remoções involuntárias, assunto extremamente importante para a nossa análise. É importante ressaltar que nos casos onde for inevitável a desapropriação, o agente governamental deve se responsabilizar pelos custos da mudança e reinstalação nas áreas próximas, além de indenizar de forma justa os moradores. Um ponto de destaque deste artigo é a implementação de programas socioeconômicos, anterior ao processo de remoção, a fim de que a situação econômica dos moradores não seja afetada de forma negativa. Mostra também a responsabilidade do Estado e demais municípios quanto à preservação do meio ambiente, devendo reduzir o impacto através de projetos sustentáveis.

Finalmente, a Lei Orgânica do Município traz no seu artigo 429, na Seção II, a qual trata do desenvolvimento urbano, o princípio da não remoção, e, novamente condiciona a exceção da desapropriação à área de

\footnotetext{
${ }^{83}$ CONSTITUIÇÃO DO ESTADO DO RIO DE JANEIRO. 1989. Assembleia Legislativa do Estado do Rio de Janeiro. Disponível em: http://www.cmresende.rj.gov.br/PDF/const_est_rj.pdf. Acessado em: 29/04/2013.
} 
risco. Portanto, para que a remoção seja realizada dentro dos parâmetros legais, alguns quesitos necessários que devem ser respeitados:

Art. 429 - A política de desenvolvimento urbano respeitará os seguintes preceitos: [...]

VI - urbanização, regularização fundiária e titulação das áreas faveladas e de baixa renda, sem remoção dos moradores, salvo quando as condições físicas da área ocupada imponham riscos de vida aos seus habitantes, hipótese em que serão seguidas as seguintes regras:

a) Laudo técnico do órgão responsável;

b) Participação da comunidade interessada e das entidades representativas na análise e definição das soluções;

c) Assentamento em localidades próximas dos locais de moradia ou do trabalho, se necessário o remanejamento ${ }^{84}$.

Tendo em vista a considerável quantidade de leis brasileiras, tanto em âmbito nacional quanto local, que defendem o direito à moradia e próibem a remoção, causa espanto as violações ocorridas mediante a instalação da estrutura para os megaeventos esportivos. As principais vítimas dessa política de remoção são os moradores de favelas, que são expropriados do seu direito à cidade e à moradia, destacando-se a população feminina.

São inúmeras as favelas que passam por este drama da ameaça de remoção e também as que já passaram por tal dissabor. Adiante, será estudado o caso da Estradinha, comunidade localizada na Ladeira dos Tabajaras, $\mathrm{n}^{\mathrm{o}}$ 1014, no bairro de Botafogo, que possui como maioria de seus habitantes, mulheres afrodescendentes, que vêm resistindo bravamente às tentativas de remoção empreendidas pelo poder público municipal. Assim, no próximo capítulo, serão abordados os aspectos demográficos e socioeconômicos da comunidade escolhida para o estudo. Além disso, serão apresentados os principais argumentos utilizados pelos poderes públicos estaduais e municipais para remover as famílias desse território.

\footnotetext{
${ }^{84}$ Lei Orgânica do Município do Rio de Janeiro. Procuradoria Geral do Município do Rio de Janeiro. 2010. Disponível em: http://200.141.78.79/dlstatic/10112/1659124/DLFE222901.pdf/LeiOrganica.pdf. Acessado em: 28/04/2013.
} 


\section{Os Caminhos da Estradinha}

Após as considerações realizadas acerca da Teoria da Interseccionalidade e da análise das legislações internacionais e nacionais de proteção ao direito à moradia, trataremos neste capítulo sobre o objeto de estudo deste trabalho: A Comunidade da Estradinha. Esta se encontra localizada na Ladeira dos Tabajaras, n 1014, acima do Cemitério São João Batista, no bairro de Botafogo, que corresponde a uma das áreas nobres da cidade do Rio de Janeiro.

A comunidade foi escolhida devido à participação ativa das mulheres na defesa do seu direito à moradia. Elas se reuniram e buscaram assistência jurídica no Núcleo de Terras e Habitação da Defensoria Pública do Estado do Rio de Janeiro (NUTH), além de se integrarem a organizações de direitos humanos. A seguir, iniciaremos o estudo sobre os aspectos históricos desta comunidade que resiste ao processo de remoção e que a cada dia se fortalece através da união de seus moradores.

\subsection{Histórico da Comunidade da Estradinha}

A busca por informações sobre o surgimento da comunidade da Estradinha foi realizada através de visitas ao Instituto Pereira Passos $(\text { IPP })^{85}$, de entrevista com moradoras e da coleta de dados disponibilizados no sistema de acesso Sistema de Assentamentos de Baixa Renda

\footnotetext{
${ }^{85}$ O Instituto Municipal de Urbanismo Pereira Passos (IPP) tem sua origem na Fundação RioPlan, instituída em 1979 e posteriormente transformada em Empresa Municipal de Informática e Planejamento (IplanRio). Com o desmembramento da empresa, em 1999, o IPP assumiu as atividades de planejamento urbano, produção cartográfica e de estatísticas do Rio de Janeiro. O IPP tem relevância como centro de referência de dados e conhecimento sobre o Rio, utilizado para a formulação e acompanhamento de políticas públicas, municipais ou não. Estas informações estão abertas para o uso e consulta da imprensa e de toda a população do Rio de Janeiro através do site Armazém de Dados, criado em 2001. Disponível em: http://ipprio.rio.rj.gov.br/o-instituto2/historia/ Acessado em: 20/05/2013.
} 
$(\mathrm{SABREN})^{86}$, presente no Armazém de Dados na página da Geo-Rio ${ }^{87}$ na internet.

Ao realizar a pesquisa nos instrumentos cedidos pelo poder público, não encontrei nenhuma informação sobre o histórico da Comunidade da Estradinha. O único dado, disponível no SABREN, sobre o assunto se refere à Ladeira dos Tabajaras, na área de Botafogo, informando que a ocupação da área começa em 1921, especificamente no número 572, arrendado pelo Sr. Augusto Jorge Rossi, que por sua vez alugou casas até a data do seu falecimento. Tendo em vista que não havia herdeiros reivindicando a posse do terreno, os moradores ali permaneceram e se estabeleceram com suas famílias, formando, assim, a comunidade. O mais interessante é que a instituição diz que esse histórico foi fornecido pelos próprios moradores, o que significa que não existe nada documentado e que o único registro do surgimento da Ladeira dos Tabajaras é aquele relatado pelos moradores.

Também não encontrei nenhum registro específico da Comunidade da Estradinha na Biblioteca do IPP, situada na Rua Gago Coutinho, no 52. Mesmo indagando a bibliotecária responsável pelos arquivos do local, não obtive êxito. Ela não encontrou material que me pudesse ser útil. Porém, permitiu meu acesso à pasta física do Complexo do Morro dos Cabritos, que engloba a Ladeira dos Tabajaras e que por sua vez abriga a Estradinha, como demonstra o quadro a seguir:

\footnotetext{
${ }^{86}$ O Sistema de Assentamentos de Baixa Renda (SABREN ) reúne desde 1983 informações sobre os assentamentos precários e informais cariocas, com o principal objetivo de apoiar a construção de políticas públicas, destinadas à sua urbanização e desenvolvimento social. Disponível em: http://portalgeo.rio.rj.gov.br/sabren/index.htlm. Acessado em: 20.05.2013.

87 O Armazém de Dados é uma iniciativa da Diretoria de Informações da Cidade do Instituto Municipal de Urbanismo Pereira Passos (IPP-RIO), autarquia vinculada à Secretaria Municipal da Casa Civil - CVL. Foi concebido para reunir contribuições não apenas do IPP-RIO, mas de toda a comunidade da Prefeitura, ou de fora dela, que produz estatísticas, mapas, estudos e pesquisas aplicadas ao Rio de Janeiro. Disponível em: http://portalgeo.rio.rj.gov.br/amdados800.asp?gtema=15. Acessado em: 20/05/2013.
} 


\section{FIGURA 01 - Localização da Ladeira dos Tabajaras}

\section{Localizaç̃o e situaçăo}

2.1 - Localizaçåo

A Comunidade Morro dos Cabrites está situada nos limites da localidade denominada Bairro do Peixoto parte noroeste do bairro de Copacabana na $V$

Regiâo Administrativa, Copacabana, na II Area de Planejamento, zoria sul da Cidade do Rio de Janeiro

O acesso à comunidade è feito com veiculos desde Copacabana partindo da Rua Siqueira Campos, na altura da Rua Toneleiros pela Ladeira dos Tabajaras, que interiga com Botafogo ate a Rua Real Grandeza, nas proximidades do Cemilério Sâo Joâo Batista, e partindo desta, na altura do número 668 , segue-se pela Rua Euclides da Rocha que atravessa a área da favela Também pela Lagoa Rodrigo de Freitas, através da Rua Vitória Régia pode-se acessar a parte noroeste da área. Os demais acessos sâo exciusivos para pedestres, através de escadarias saindo da Rua Santa Clara.

Fonte: Biblioteca do Instituto Pereira Passos.

Ao folhear o material, encontrei o histórico do complexo acima citado e suas dimensões, que data a ocupação na década de 20. Registra, ainda, que a localidade já passava pelo processo de remoção desde o início da década de 1970, como se pode ver no recorte do documento fotografado na biblioteca, abaixo destacado:

\section{FIGURA 02 - Histórico da Ladeira dos Tabajaras}

Na década de 20, mais precisamente em 1926, tove inicio a ocupaçăo do terreno onde está implantada a Comunidade, com a construçấo de alguns barracos para a locaçâo, principalmente para migrantes da regiâo nordeste e do sul de Minas Gerais. Essas habitapbes foram erguidas por um senhor portugués que se dizia dono das terras.

Nessa mesme epoca. com o adensamento do bairro de Copacabana, formaram-se no local principaimente na regiào atualmente ocupada pela rua Euclides da Rocha. pequenas chacaras para o cultivo de árvores frutiferas

A partir de meados do século XX a ocupacấo irregular das encostas aumentou o desmatamento dos Morros A devastaçắo da cobertura vegetal dos Morros dos Cabritos e da Saudade ocorreu a partir da década de 1960, quando as favelas do Cantagalo e da Catacumba ocuparam porçấo significativa do Morro dos Cabritos na vertente que dé para a Lagoa A fixaçấo dessas comunidades em tal local levou à remoçào de boa parte da vegetaçăo original de Mata Atlántica No inicio da década de 1970 , fo removida a Favela da Catacumba, que possuia uma população estimada em 10 mil habitantes Em 1979, foi implantado no local anteriormente ocupado pela favela o Parque Carlos Lacerda, conhecido por Parque da Catacumbe

Fonte: Biblioteca do Instituto Pereira Passos. 
Além disso, o quadro abaixo, encontrado na página do SABREN, traz a identificação oficial da Comunidade pelo Instituto Pereira Passos, que é catalogada como favela ${ }^{88}$ na classificação deste sistema:

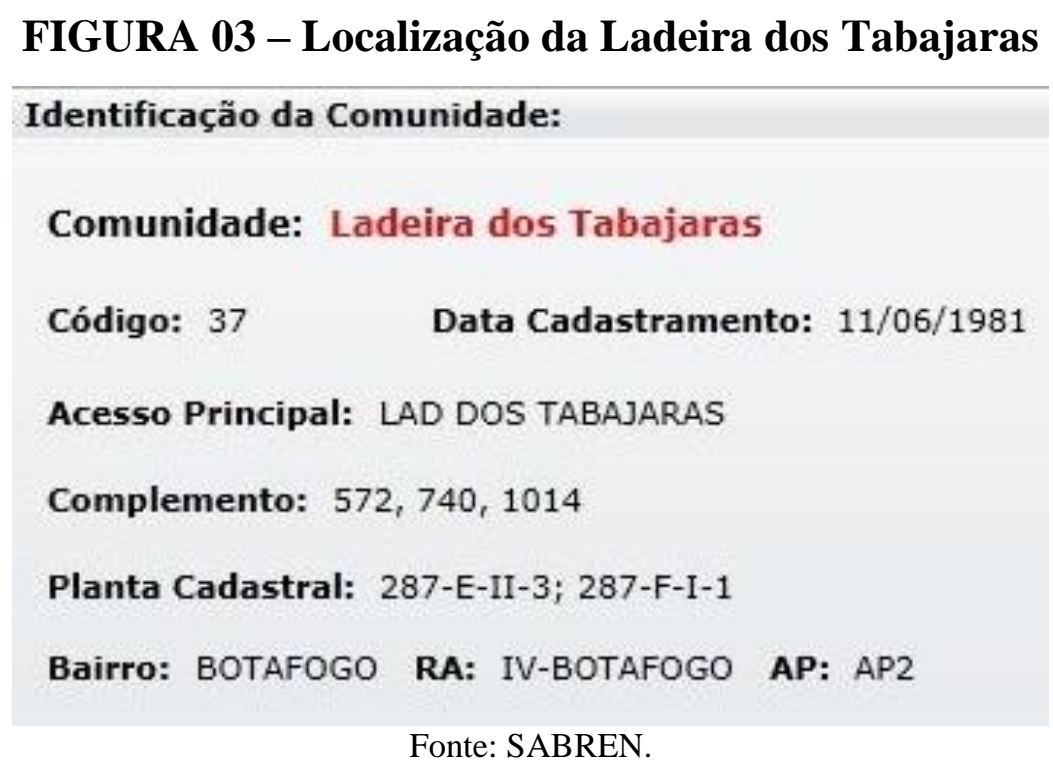

No entanto, o SABREN faz apenas uma referência à área da Estradinha, quando trata sobre a identificação alternativa, que geralmente é o nome pelo qual os moradores identificam um território específico, nesse caso a Ladeira dos Tabajaras:

\section{FIGURA 04 - Identificação Alternativa da Ladeira dos Tabajaras}

\footnotetext{
88 Segundo o SABREN, a favela é definida como área predominantemente habitacional, caracterizada por ocupação clandestina e de baixa renda, precariedade da infraestrutura urbana e de serviços públicos, vias estreitas e alinhamento irregular, ausência de parcelamento formal e vínculos de propriedade e construções não licenciadas, em desacordo com os padrões legais vigentes. Disponível em: http://portalgeo.rio.rj.gov.br/sabren/. Acessado em: 20/05/2013.
} 


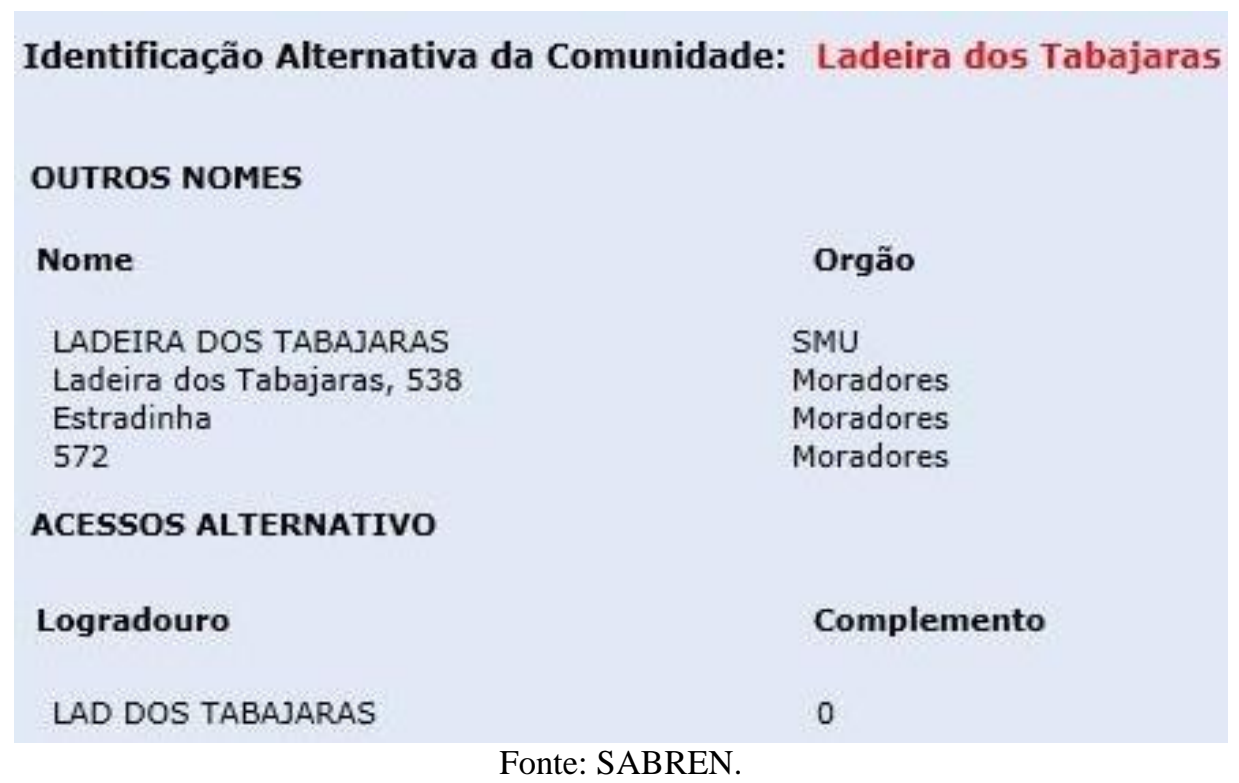

Desta maneira, é possível perceber que existem outras comunidades dentro da localidade, as quais são identificadas pelos moradores. Porém, a Secretaria Municipal de Urbanismo (SMU) parece reconhecer apenas a Ladeira dos Tabajaras como um todo, sem perceber suas especificidades. Ainda assim, a Estradinha surge como uma das áreas pertencentes ao complexo, de acordo com os seus habitantes.

Sendo assim, decidi reconstruir o histórico da comunidade através dos relatos de seus próprios moradores. Ao procurar a Associação de Moradores da Estradinha, fui atendida pela Sra. Fátima de Amorim, sua vice-presidente, que gentilmente me cedeu um arquivo de registro desta história. O material cedido informa que o local em questão também é conhecido por Morro São João Baptista, pela proximidade ao Cemitério São João Baptista. A Estradinha 1014, como é conhecida por seus habitantes, recebeu essa nomenclatura porque é o nome da rua que dá acesso à comunidade. Segundo o registro adquirido, o Morro São João existe desde 1921. Os primeiros ocupantes da Estradinha foram 19 famílias que chegaram em 1952. Eram famílias dos funcionários do cemitério São João Baptista, que ali foram alocadas com a permissão da Santa Casa de Misericórdia, a qual era administradora e concessionária do cemitério desde a sua criação no século XIX. Nunca houve regularização de posse àquela época, porém a favela começou a se expandir mais tarde, no ano de 1976. 
Em 1987, na gestão do prefeito Saturnino Braga, foi realizado o assentamento de 42 famílias, com o suporte da associação de moradores. À época houve um estudo técnico da região, realizado pela Geo-Rio ${ }^{89}$, constatando a segurança do solo para a construção das casas. Os moradores foram acompanhados pela Secretaria de Desenvolvimento Social, a qual providenciou aos moradores que não tinham condições de construir suas residências, um "kit construção". Esse kit consistia na cessão de materiais de construção para as famílias hipossuficientes. Em seguida, a comunidade foi mapeada e dividida em lotes, sendo que cada casa possuía sua planta baixa. Após este mapeamento, as casas foram construídas, através de mutirões, pelos próprios moradores. O processo de assentamento foi registrado sob os números 04/551.600/1985 e 04/550485/1986.

Na década de 1990, a Estradinha foi alvo de um dos programas da Secretaria Municipal de Habitação (SMH), conhecido por Favela-Bairro ${ }^{90}$, cujo objetivo era promover a integração das favelas à cidade do Rio de Janeiro. É possível comprovar a implementação do projeto no local através dos documentos encontrados na pasta do Morro dos Cabritos, os quais pertencem a este programa habitacional do Município. Os programas Favela-Bairro 1 e 2, foram implementados na comunidade, contudo, as obras restaram inacabadas.

Assim, em 31 de Outubro de 2000, o prefeito Luiz Paulo Fernandez Conde sancionou a Lei N. $3.122 / 2000^{91}$, que declara a área total do morro dos Cabritos como Área de Especial Interesse Social (AEIS) ${ }^{92}$, para fins de

\footnotetext{
${ }^{89}$ Instituto de Geotécnica do Município do Rio de Janeiro (GEO-RIO).

${ }^{90}$ Coordenado pela Secretaria Municipal de Habitação e financiado pelo Banco Interamericano de Desenvolvimento (BID), o programa implanta infraestrutura urbana, serviços, equipamentos públicos e políticas sociais nas comunidades beneficiadas. Disponível em: http://www.rio.rj.gov.br/habitacao/favela_bairro.htm. Acessado em 21/04/2013.

${ }^{91}$ Lei 3122/2000 - Declara como de Especial Interesse Social, para fins de urbanização e regularização, as áreas faveladas delimitadas no anexo, e estabelece os respectivos padrões especiais de urbanização. Anexo: Morro dos Cabritos (V R.A Copacabana). Disponível em: http://mail.camara.rj.gov.br/APL/Legislativos/contlei.nsf/d38566aa34930b4d03257960005fdc91/7 ad996f597e88a3a032576ac0072e80a?OpenDocument. Acessado em 21/04/2013.

92 São zonas urbanas destinadas ao uso habitacional, ou seja, integram o perímetro urbano do município e devem possuir infraestrutura e serviços urbanos ou garantir a viabilidade da sua implantação. Devem ser criadas por lei (Plano Diretor ou outra lei municipal). São áreas destinadas predominantemente à população de baixa renda, independentemente de tratar-se de
} 
urbanização e regularização. Posteriormente, o Morro São João Baptista, outro nome dado à comunidade da Estradinha, é instituído como Área de Proteção Ambiental, através da Lei no 5019/2009, assinada pelo prefeito Eduardo Paes. Segundo o relato adquirido na Associação de Moradores, no mesmo ano é (APA) que começam os indícios de que a comunidade seria removida.

Em dezembro de 2009, os jornais locais publicaram notícias sobre as remoções de diversas favelas na cidade do Rio de Janeiro, dentre elas a área pertencente à Estradinha. O interessante é perceber que após a divulgação das remoções na mídia, os agentes da Secretaria Municipal de Habitação (SMH) deram início ao cadastramento das residências, inclusive fotografando o interior e o exterior das casas, sem informar o que se pretendia com tal ação. Diante do questionamento dos moradores sobre o cadastramento ou da proibição da entrada nos domicílios, os representantes da prefeitura alegaram que se tratava de parte do Censo Nacional de 2010.

Este cadastramento foi realizado antes do período das fortes chuvas que assolaram a cidade do Rio de Janeiro em abril de 2010. No dia 10 de março do ano em questão, a comunidade recebeu a visita do engenheiro Maurício Campos ${ }^{93}$ que fez uma vistoria no local, a fim de elaborar um estudo técnico sobre a localidade. Em seguida, especificamente no dia 24 do mesmo mês, a Concremat, empresa de engenharia prestadora de serviços contratada pela prefeitura, visitou a comunidade, acompanhada dos

\footnotetext{
áreas previamente ocupadas por assentamentos populares ou de áreas vazias e subutilizadas. Para atender a essa destinação, nas áreas vazias, a legislação da ZEIS deve prever a aplicação articulada dos instrumentos de indução do desenvolvimento urbano e cumprimento da função social da propriedade. Podem ser classificadas em dois tipos básicos: a) ZEIS de áreas ocupadas por assentamentos precários; b) ZEIS de áreas vazias ou subutilizadas, em áreas infraestruturadas. Ministério das Cidades. Brasília 2009. Disponível em: https://www.google.com.br/url?sa=t\&rct=j\&q=\&esrc=s\&source=web\&cd=3\&cad=rja\&ved=0CD gQFjAC\&url=http\%3A\%2F\%2Fwww.mp.mg.gov.br\%2Fportal\%2Fpublic\%2Finterno\%2Farquivo \%2Fid\%2F14599\&ei=AeWvUZSsE9H94APSwoGQDA\&usg=AFQjCNGsnmSkXsB1SzrZWi3gf ClXCnO8Yw\&sig2=cKtnkB9mZ1D3MW5AC04sZw\&bvm=bv.47534661,d.dmg. Acessado em: 21/04/2013.

${ }^{93}$ Maurício Campos é colaborador de um coletivo técnico formado por engenheiros e arquitetos que prestam serviços de análise técnicas a diversas comunidades do Rio de Janeiro.
} 
moradores, realizando apenas uma vistoria visual em toda área da Estradinha.

Desta maneira, em 05 de abril de 2010, dia da grande chuva, houve um pequeno deslizamento num local próximo, devido a um corte irregular feito pela Santa Casa de Misericórdia, que por sua vez não afetou nenhuma das habitações da Estradinha. Logo após, a prefeitura continuou assediando a comunidade até que no dia 24 de abril ocorreu uma reunião com a $\mathrm{SMH}$ com a participação do Sr. Reinaldo Reis, Presidente da Associação de Moradores da Estradinha, do Sr. Carlos Roberto Osório - Secretário Municipal de Conservação e Serviços Públicos, do Sr. Pierre Alex Domiciano Batista - Secretário Municipal de Habitação, do Sr. Fernando William Ferreira - Secretário Municipal de Assistência Social, do Sr. Michael - Engenheiro da Secretaria Municipal de Habitação, do Dr. Douglas - Advogado da associação de Moradores, do Sr. Bruno Ramos Subprefeito da Zona Sul e da Dra. Adriana Britto - Defensora Pública do Núcleo de Terras e Habitação.

Nesta reunião, a Secretaria de Habitação atemorizou os moradores, sob a ameaça de ficarem sem suas casas, alegando que toda a comunidade estava condenada e que para não perderem tudo, deveriam negociar com a Prefeitura. Os agentes do Município inclusive citaram a tragédia ocorrida no Morro do Bumba, em Niterói, no qual houve deslizamento de terra atingindo as casas e deixando dezenas de vítimas. Sendo assim, a comunidade entrou em pânico e começou a negociar suas casas no mesmo instante. No dia seguinte à reunião, metade da comunidade já havia negociado suas habitações e posteriormente deu-se início à remoção da comunidade.

Este é o histórico registrado pela comunidade e disponibilizado pela vice-presidente da associação de moradores. Ao longo deste capítulo será analisado o contexto no qual ocorreu a remoção parcial, o conceito de área de risco, principal argumento defendido pelo poder munícipe para a retirada das famílias. A seguir, observaremos os aspectos demográficos e os dados 
socioeconômicos da Ladeira dos Tabajaras - lado Botafogo, conforme o

Censo 2010, produzido Instituto Brasileiro de Geografia e Estatística (IBGE).

\subsection{Aspectos Demográficos e Dados Socioeconômicos.}

Neste item, partindo das informações produzidas pelo IBGE, no Censo 2010, a composição da população da Ladeira dos Tabajaras será interpretada, considerando a perspectiva da interseccionalidade. Assim, compreender-se-á a invisibilidade da população afrodescendente e feminina nas políticas de reordenamento do espaço urbano.

Primeiramente, faz-se necessário recordar que o termo a definir as favelas e comunidades no censo em questão é "aglomerados subnormais ${ }^{94, "}$ Este termo, apesar de sua conotação negativa não apenas em relação às construções, mas aos moradores de áreas favelizadas, ainda é utilizada como parâmetro para o conceito de moradia adequada. Desta forma, a Ladeira dos Tabajaras, que está abarcada por este conceito é composta por 424 domicílios, somando um total de 1.369 habitantes, dentre os quais 684 são homens e 675 são mulheres, conforme o quadro abaixo:

\footnotetext{
${ }^{94}$ É um conjunto constituído de, no mínimo, 51 unidades habitacionais (barracos, casas etc.) carentes, em sua maioria de serviços públicos essenciais, ocupando ou tendo ocupado, até período recente, terreno de propriedade alheia (pública ou particular) e estando dispostas, em geral, de forma desordenada e densa. A identificação dos aglomerados subnormais deve ser feita com base nos seguintes critérios: a) Ocupação ilegal da terra, ou seja, construção em terrenos de propriedade alheia (pública ou particular) no momento atual ou em período recente (obtenção do título de propriedade do terreno há 10 anos ou menos); e b) Possuírem pelo menos uma das seguintes características: urbanização fora dos padrões vigentes - refletido por vias de circulação estreitas e de alinhamento irregular, lotes de tamanhos e formas desiguais e construções não regularizadas por órgãos públicos; ou precariedade de serviços públicos essenciais. Os aglomerados subnormais podem se enquadrar, observados os critérios de padrões de urbanização e/ou de precariedade de serviços públicos essenciais, nas seguintes categorias: invasão, loteamento irregular ou clandestino, e áreas invadidas e loteamentos irregulares e clandestinos regularizados em período recente. Censo Demográfico 2010. Aglomerados Subnormais - Primeiros Resultados. IBGE, Rio de Janeiro, 2011. p.19. Disponível em: http://biblioteca.ibge.gov.br/visualizacao/periodicos/92/cd_2010_aglomerados_subnormais.pdf. Acessado: 25/04/2013.
} 


\section{TABELA 01 - Domicílios particulares em aglomerados subnormais, população residente por sexo e media de moradores}

\begin{tabular}{|c|c|c|c|c|c|}
\hline \multicolumn{6}{|c|}{$\begin{array}{l}\text { Tabela } 2 \text { - Domicilios particulares ocupados em aglomerados subnormais, populaçāo residente } \\
\text { em domicilios particulares ocupados em aglomerados subnormais, por sexo, e média de moradores } \\
\text { em domicilios particulares ocupados em aglomerados subnormais, segundo as Grandes Regiōes, } \\
\text { as Unidades da Federaçāo, os municipios es aglomerados subnormais - } 2010\end{array}$} \\
\hline \multirow{2}{*}{$\begin{array}{l}\text { Grondes Pogióes, } \\
\text { Unidodes da Federaģa, } \\
\text { municipios e oglomarados subnormais }\end{array}$} & \multirow{2}{*}{$\begin{array}{l}\text { Domicilios } \\
\text { porticulares } \\
\text { ocupados em } \\
\text { oglomerados } \\
\text { subnormais }\end{array}$} & \multicolumn{3}{|c|}{$\begin{array}{l}\text { Populaģä́o rosidanta em domicilios particulares } \\
\text { ocupados em oglomerados subnormais }\end{array}$} & \multirow{2}{*}{$\begin{array}{l}\text { Midia do } \\
\text { muradores om } \\
\text { domicilios } \\
\text { perticulares } \\
\text { ocupados am } \\
\text { oglomerados } \\
\text { subnormsis }\end{array}$} \\
\hline & & Totsil & Homens & Mulhenes & \\
\hline \multicolumn{6}{|l|}{ Rio do Janoiro } \\
\hline Jardim Nosaa Sonhora das Grocas III & 70 & 247 & 113 & 134 & 3,5 \\
\hline Jardirn Piedado & 898 & 3071 & 1501 & 1570 & 3,4 \\
\hline Jardim Sbo Bento & 185 & 554 & 256 & 298 & 3,0 \\
\hline Joequim de Quairuir & 2445 & 8169 & 4023 & 4136 & 3,3 \\
\hline Jaaquim Magalhảes & 127 & 402 & 193 & 209 & 3,2 \\
\hline Joaquim Meiar & 76 & 285 & 133 & 132 & 3,5 \\
\hline Jülio Otoni & 231 & 758 & 387 & 391 & 3,3 \\
\hline Ladeirs da Rounibo & 339 & 1176 & 562 & .614 & 3,5 \\
\hline Lodaira dos Funcionirios & 324 & 1119 & 531 & 589 & 3,5 \\
\hline Ladoira dos Tabajaras & 424 & 1359 & 694 & 675 & 3,2 \\
\hline Largo do Cormas & 265 & 870 & 418 & 452 & 3,3 \\
\hline Largo do Corrua 1 & 496 & 1592 & 778 & 814 & 3,2 \\
\hline Linha do Austin & 573 & 1963 & 962 & 1001 & 3,4 \\
\hline Lote 1.000 & 192 & 590 & 312 & 278 & 3,1 \\
\hline Lotoamento Jasué & 200 & 722 & 369 & 353 & 3.6 \\
\hline Loteamanto Sáo Sobastis̄o & 115 & 371 & 174 & 197 & 3,2 \\
\hline
\end{tabular}

Fonte Censo 2010 - IBGE

Neste primeiro contato com a análise da população da Ladeira dos Tabajaras, num sentido geral, já é possível perceber que praticamente metade dos seus habitantes é formada por mulheres, o que justifica uma necessidade de se refletir sobre o direito à moradia para esta comunidade com um recorte de gênero. Outro ponto importante a ser abordado é a definição de domicílios particulares, considerada no gráfico acima. Tal termo é traduzido como o "domicílio onde o relacionamento entre seus ocupantes era ditado por laços de parentesco, de dependência doméstica ou por normas de convivência ${ }^{95}$ ". A dependência doméstica é definida pelo Censo 2010 da seguinte maneira:

[...] a situação de subordinação dos empregados domésticos e agregados em relação à pessoa responsável pelo domicílio e por normas de convivência, as regras estabelecidas para convivência de pessoas que residiam no mesmo domicílio e não estavam ligadas por laços de parentesco nem de dependência doméstica $^{96}$.

\footnotetext{
95 Ibid.

${ }^{96}$ Ibid p. 19-20.
} 
Por sua vez, observando a população referente à Ladeira dos Tabajaras - Lado Botafogo, área onde se encontra a Estradinha, pode-se verificar mais uma vez, que a população feminina compõe mais da metade da população dessa localidade. $\mathrm{O}$ gráfico abaixo mostra a população residente de acordo com a idade e o sexo:

\section{GRÁFICO 02 - População residente por sexo e idade}

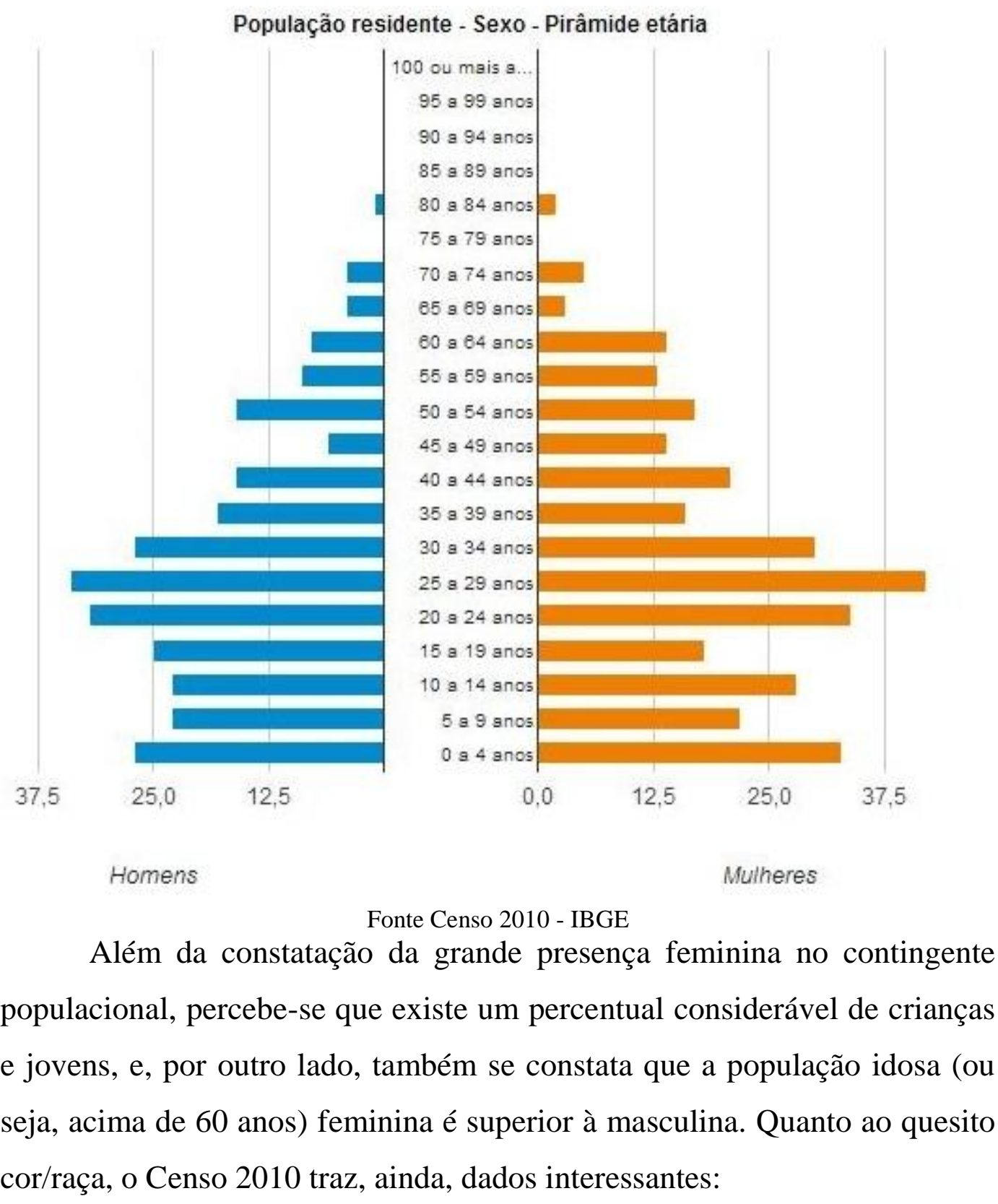




\section{GRÁFICO 03 - População residente por cor ou raça}



\section{Síntese dos dados}

\section{Dados em formato painel}



Fonte Censo 2010 - IBGE

Conforme o gráfico acima, os brancos constituem 27, $9 \%$ dos habitantes da região, enquanto os amarelos correspondem a apenas $0,9 \%$ da população residente na comunidade da comunidade. Considerando que a população preta (13\%) e parda (58.3\%) configuram o contingente de afrodescendentes, somando um total de 71,3\%, identifica-se um importante recorte racial, tendo em vista que se constituem como maioria da população.

Adiante, o próximo quadro mostrará quais os tipos de residências que compõem a comunidade e quais as suas condições de ocupação: 


\section{GRÁFICO 04 - Domicílios particulares segundo o tipo e condição de ocupação}

\begin{tabular}{|c|c|c|c|c|c|}
\hline Pais & UF & Municipio & Subdistrito & Bairro & Setor \\
\hline \multicolumn{6}{|c|}{ Setor 330455705090464} \\
\hline \multicolumn{6}{|c|}{$\begin{array}{l}\text { Brasil > Rio de Janeiro > Rio de Janeiro > Rio de Janeiro > Botafogo }>\text { Setor } \\
330455705090464\end{array}$} \\
\hline
\end{tabular}

\section{Síntese dos dados}

Dados em formato painel

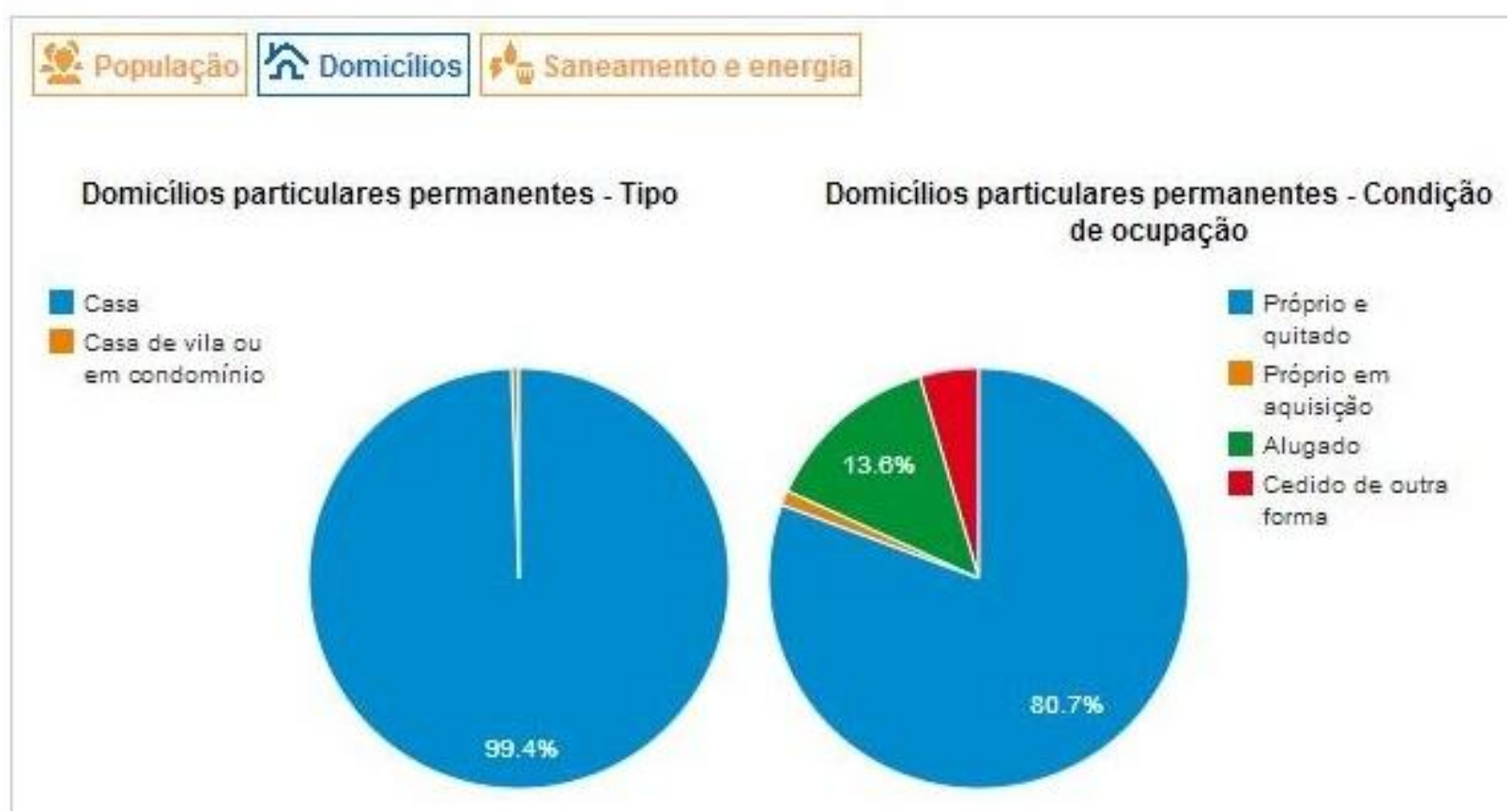

Fonte Censo 2010 - IBGE

Conforme o gráfico acima $99,4 \%$ dos domicílios permanentes ${ }^{97}$ são casas e, dentre eles $80,7 \%$ são imóveis quitados e próprios e apenas 13,6\% estão destinados à locação. Sendo assim conclui-se que a maioria dos habitantes da região são proprietários dos seus imóveis.

Há ainda outro tipo de análise que se relaciona com os dados sobre os domicílios particulares permanentes e se faz útil para este estudo, que é a quantidade de moradores por domicílio. O gráfico abaixo mostra que a

\footnotetext{
${ }^{97}$ É o imóvel construído para servir, exclusivamente, à habitação e, na data de referência, tinha a finalidade de servir de moradia a uma ou mais pessoas. Ibid. p.20.
} 
maioria da população da Ladeira dos Tabajaras possui de 3 a 7 moradores, por residência, demonstrando assim que há uma grande quantidade de moradores por domicílio, sugerindo a presença de grandes famílias.

\section{GRÁFICO 05 - Quantidade de moradores por domicílios particulares permanentes}

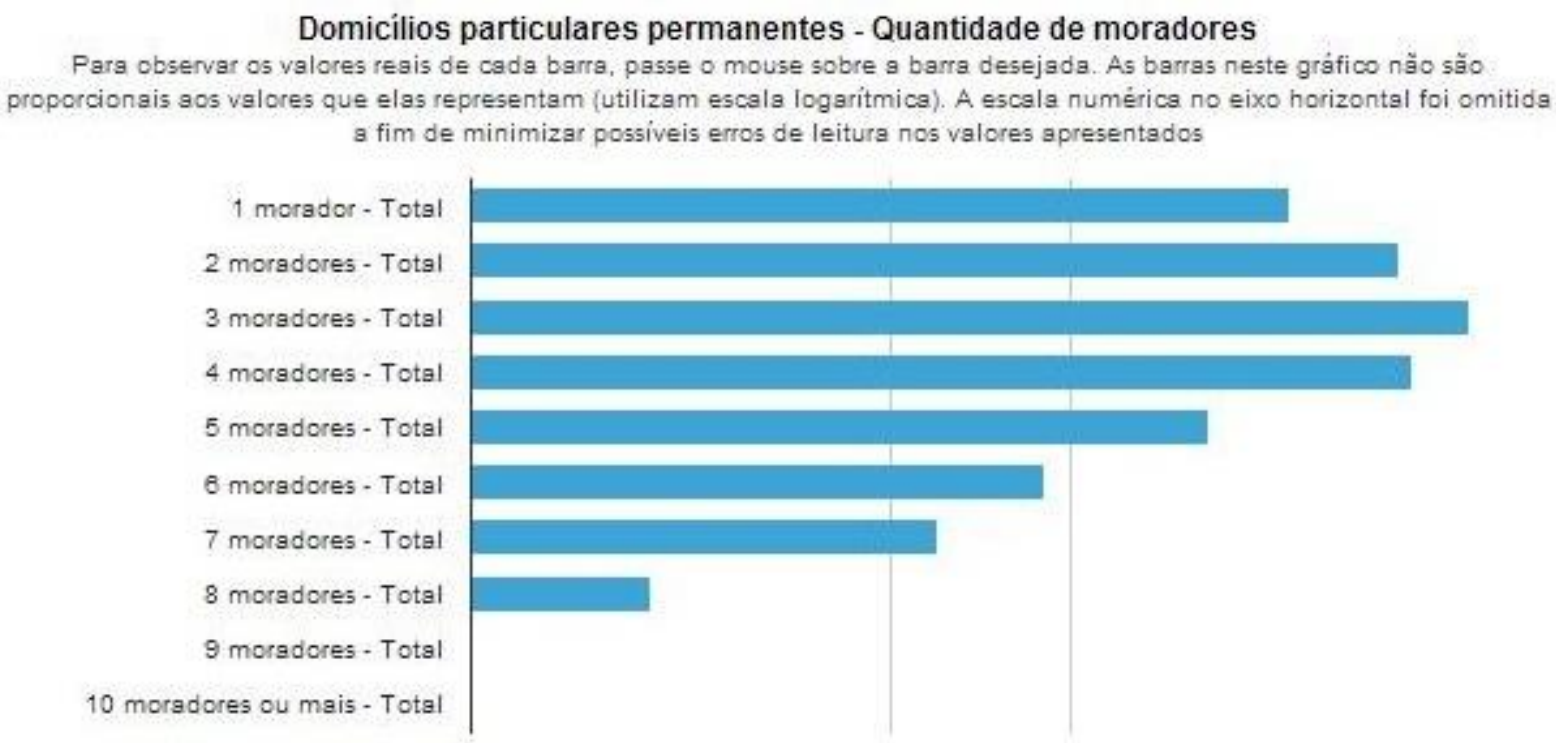

Fonte Censo 2010 - IBGE

Partindo desta análise inicial sobre a Ladeira dos Tabajaras - Lado Botafogo, é possível extrair alguns dados ${ }^{98}$ importantes para a nossa pesquisa:

a) A comunidade possui um percentual significativo de mulheres, constituindo praticamente metade da população (312 mulheres x 273 homens);

b) A maioria da população de crianças (55 - de 0 a 9 anos), jovens (76 - de 20 a 29 anos) e idosos (10 - acima de 60 anos) é feminina;

c) A maioria dos seus habitantes $(71,3 \%)$ é composta por afrodescendentes;

\footnotetext{
${ }^{98}$ Os dados a seguir são calculados de acordo com os entrevistados pelo Censo 2010. Os números entre parênteses correspondem à quantidade de habitantes ou domicílios visitados pelos agentes censitários. Disponível em: http://www.censo2010.ibge.gov.br/agsn/. Acessado em: 29.05.2013.
} 
d) Quase $100 \%$ dos imóveis da comunidade são casas, sendo em sua maioria próprios e quitados;

e) A maioria das residências (115 unidades habitacionais) abriga famílias constituídas por 3 a 6 pessoas.

Desta maneira, a partir das reflexões realizadas sobre a interseccionalidade, existem diferentes opressões invisibilizadas no caso em questão, na medida em que inter-relacionam raça, gênero, classe, situação geográfica, idade, etc. Assim, as intervenções governamentais no espaço urbano carioca, no caso sob exame, trata-se da remoção, não observam os fatores que se inter-relacionam e esta invisibilidade por parte do poder público vulnerabilizam ainda mais a comunidade. Além disso, ao remover os moradores da Estradinha, o poder público empreende uma espécie de limpeza étnica, quando retira uma população afrodescendente de uma área bastante valorizada para realocar em locais muito distantes dos centros econômicos e culturais da cidade. Isso retoma a política de branqueamento, que era subjacente às reformas urbanas realizadas na cidade do Rio de Janeiro, no início do século XX, pelo prefeito Pereira Passos. Essa política é implementada de maneira que os brancos possam ocupar os lugares mais privilegiados na cidade, refletindo não apenas na questão da moradia, mas também no acesso ao mercado de trabalho formal, aos bens e serviços públicos e privados. Portanto, a segregação racial do espaço urbano ${ }^{99}$ é fomentada continuamente pelas políticas de remoção.

\footnotetext{
${ }^{99} \mathrm{O}$ Estado, por meio das intervenções urbanas, promove, nas últimas três décadas do século XIX, intensa demolição das áreas ocupadas pelos grupos de pobres, sobretudo de escravos de ganhos, ex-escravos e migrantes, buscando a modernização do espaço urbano em várias cidades brasileiras. Porém, é na primeira década do século XX que essa modalidade de atuação deixa marcas sócioespaciais em toda a sociedade: nas classes de maior poder aquisitivo, o sentido de recuperação de uma área intensamente degradada pelo uso dos mais pobres; para estes últimos, a intervenção urbana do início do século representou a periferização, ou seja, o deslocamento compulsório para as favelas localizadas nas proximidades da área central ou a ocupação de espaços abertos ao longo dos trilhos ferroviários, inaugurados desde a década de 1870. Nas décadas seguintes do século XX, o Estado, por meio de políticas públicas de planejamento, reforça e mantém os valores segregacionistas por meio dos investimentos que valorizavam ainda mais as amenidades espaciais tão a gosto dos grupos de maior poder aquisitivo. Os planos Agache, Doxiadis, PUB-Rio, Plano Diretor Decenal da Cidade do Rio de Janeiro (todos bancados pela administração municipal) e mais o PIT-Metrô (governo federal) contribuíram em larga medida para o deslocamento compulsório dos grupos de afrodescendentes da área central da cidade, reforçando ainda mais o sistema simbólico do racismo criado principalmente na vigência de valores higienistas. A
} 
É importante ressaltar que, apesar da implementação das remoções/branqueamento por parte do governo, o IBGE constatou em suas recentes pesquisas que a população brasileira tende a se tornar (ou pelo menos a se declarar) mais negra. Assim diz o artigo de Antônia dos Santos Garcia sobre o assunto:

[...] ainda marcado pela ideologia do branqueamento, na última década, a PNAD/2009 mostra que continua aumentando o número de pessoas que se declararam pretas e pardas (negras), com o contingente negro mais significativo na população masculina ( $48,3 \%$ branca e $51,8 \%$ negra), enquanto as mulheres são $49,5 \%$ brancas e $49,5 \%$ negras. No Censo Demográfico 2010 e usando o mesmo conceito de autodeclaração para atribuir cor e raça, dentro das classificações preto, pardo, amarelo e indígena, esta tendência se confirma. O Brasil contemporâneo é mais negro, mais velho e mais feminino ${ }^{100}$.

A afirmação destacada no texto acima informa que a atual população brasileira é mais feminina, mais negra e mais velha. Retomando a análise dos dados demográficos sobre a comunidade da Estradinha é realmente possível enxergar que o seu diagnóstico se coaduna com a nova realidade do Brasil. Desta maneira, a análise do contingente populacional da Ladeira dos Tabajaras é fundamental para compreender quem são as principais vítimas do processo de remoção: uma população afrodescendente, pobre, marcadamente feminina.

No próximo item, veremos os argumentos utilizados pela Prefeitura para remover a comunidade da Estradinha e a contra-argumentação realizada por moradores, notadamente mulheres, para combater tal política pública.

participação do Estado é fundamental no processo de promoção da segregação socioespacial no sistema urbano do país, que, por sua vez, contribuiu para a que os mais pobres urbanos, sobretudo os afrodescendentes, vissem agravar todos os tipos de preconceitos: das questões étnico-raciais à acessibilidade ao sistema educacional e ao mundo do trabalho, da ineficiência das políticas de saúde e educação à pouca atenção voltada para infraestrutura básica que promovesse mais justiça social e maior qualidade de vida. CAMPOS, Andrelino O. O Planejamento Urbano $e$ a "Invisibilidade" dos Afrodescendentes - Discriminação étnico-racial, intervenção estatal $e$ segregação socioespacial na cidade do Rio de Janeiro. 2006. p. 14. Disponível em: http://www.ppgg.igeo.ufrj.br/index.php?option=com docman\&task=doc details\&gid=72\&Itemid =99999999. Acessado em: 29.05.2013.

${ }^{100}$ GARCIA, Antonia dos Santos. Mulher Negra e o Direito à Cidade: Relações raciais e de gênero. IN: SANTOS, Renato Emerson dos (Org.). Questões Urbanas e Racismo. Petrópolis-RJ, 2012. Ed. De Petrus e Alii Editora. p. 140. 


\subsection{Especulação imobiliária: os descaminhos da Estradinha}

A política de remoção implementada no Rio de Janeiro atingiu e continua atingindo diversas comunidades da cidade. Os locais mais afetados são aqueles nos quais a valorização imobiliária aumentou de forma desproporcional, em conjunto com a notícia de que a cidade sediará os megaeventos esportivos em 2014 e 2016: A Copa do Mundo e as Olimpíadas. Essa grande valorização dos espaços urbanos tornou-se objeto de cobiça dentre empresários e investidores, devido aos lucros exorbitantes, o que impulsionou a retirada da população pobre e favelada das áreas consideradas nobres.

No entanto, os motivos alegados pelo poder público para a execução desta política são: a) danos ambientais; b) população situada em área de risco; c) adequação da cidade à estrutura exigida pelo Comitê Olímpico, como por exemplo, a mobilidade urbana. Além disso, a falta de informação sobre o direito à moradia e os boatos/rumores espalhados nas comunidades contribuem para a aceitação da remoção pelos moradores, que desesperados e sem saber para onde ir, muitas vezes terminam por aceitar qualquer proposta apresentada pela Prefeitura.

Quanto ao caso da Estradinha, existem diversos pontos controversos, no que diz respeito aos argumentos da Prefeitura. Apesar de ser declarada como AEIS, em 2000, para fins de regularização fundiária e urbanização, a localidade foi declarada como área de risco por um relatório elaborado pela GEO-RIO, em 2010 (ver em anexo). O fato mais interessante é que os moradores relatam que nunca houve nenhuma vistoria do órgão no local, para verificação do solo.

Ao analisar o material cedido pelo Dr. Maurício Campos, engenheiro civil e mecânico, membro do corpo de assessores técnicos do NUTH da Defensoria Pública do Estado do Rio de Janeiro, percebe-se a superficialidade do laudo outrora apresentado pela GEO-RIO. A visita do 
Dr. Maurício foi acompanhada pela Associação de Moradores do Tabajaras Botafogo e pela Comissão de Moradores da localidade. Seu objetivo era pontuar as seguintes questões:

a) Vistoriar todos os pontos de incidentes apontados pelos moradores, inclusive sugerir medidas imediatas de precaução;

b) Vistoriar o conjunto da comunidade, em particular a montante das áreas ocupadas ou atingidas por deslizamentos, para averiguar a presença visível de sinais que indicassem iminência de novos deslocamentos de taludes;

c) Vistoriar as principais obras de contenção executadas, para averiguar de que modo funcionaram as recentes chuvas, e a sua integridade ou não;

d) Confrontar a situação dos trechos de encostas da comunidade com as descrições e conclusões apresentadas pela Prefeitura do Rio, em particular aquelas em que se apresenta a suposta necessidade de remoção completa da comunidade como única maneira viável de se enfrentar o declarado "alto risco" de suas encostas ${ }^{101}$.

Sendo assim, a partir desta vistoria, o Dr. Maurício Campos emitiu um Parecer Técnico (ver em anexo), que além de mostrar a fragilidade do laudo apresentado pela Prefeitura, apresenta ainda soluções para o local, afastando a possibilidade de remoção da comunidade, como veremos adiante. Segundo este parecer, a Fundação GEO-RIO enviou ao NUTH, através de um ofício em 19.05.2010, o relatório de “Avaliação do Risco Geológico-geotécnico associado a Escorregamentos para a comunidade Estradinha, a montante do cemitério São João Baptista". Contudo, este relatório, enviado em maio de 2010, reproduz quase todo o conteúdo do relatório anterior, de abril do mesmo ano, o qual fora destinado às comunidades da Estradinha, Laboriaux (Rocinha), Morro do Fogueteiro, Morro dos Prazeres e Escondidinho, Morro dos Urubus e Complexo do Turano (ver em anexo), apenas com algumas diferenças.

Portanto, o Parecer Técnico levanta os seguintes pontos relevantes:

\footnotetext{
${ }^{101}$ CAMPOS, Maurício. Relatório sobre a visita técnica realizada na comunidade da Ladeira dos Tabajaras (Estradinha 1014, Botafogo) em 10 de Maio de 2010, e Parecer Técnico sobre os motivos alegados pela Prefeitura do Rio de Janeiro para a remoção completa da comunidade. p. 01 .
} 
1) Quanto aos aspectos da ocupação e características geológicogeotécnicas:

1.a) Identificação da ocupação da Comunidade Ladeira dos Tabajaras - Botafogo (acima do cemitério São João Batista) desde 1921, de acordo com os registros de aerofotos do SABREN; 1.b) Não houve expansão horizontal significativa da área nos últimos 10 anos de acordo com os valores $\left(\mathrm{em} \mathrm{m}^{2}\right)$, porém há um crescimento vertical das edificações, comum em todas as favelas cariocas, o que acaba com o argumento da Prefeitura de que o crescimento da comunidade causa dano ambiental; 1.c) Identificação da maioria das edificações nas proximidades da principal rua de acesso à comunidade, entre as cotas 50 e $125 \mathrm{~m}$, como se pode observar na figura abaixo, obtida pelo Mapoteca do Armazém de Dados da Prefeitura do Rio ${ }^{102}$ :

\section{FIGURA 05 - Localização da Ladeira dos Tabajaras}

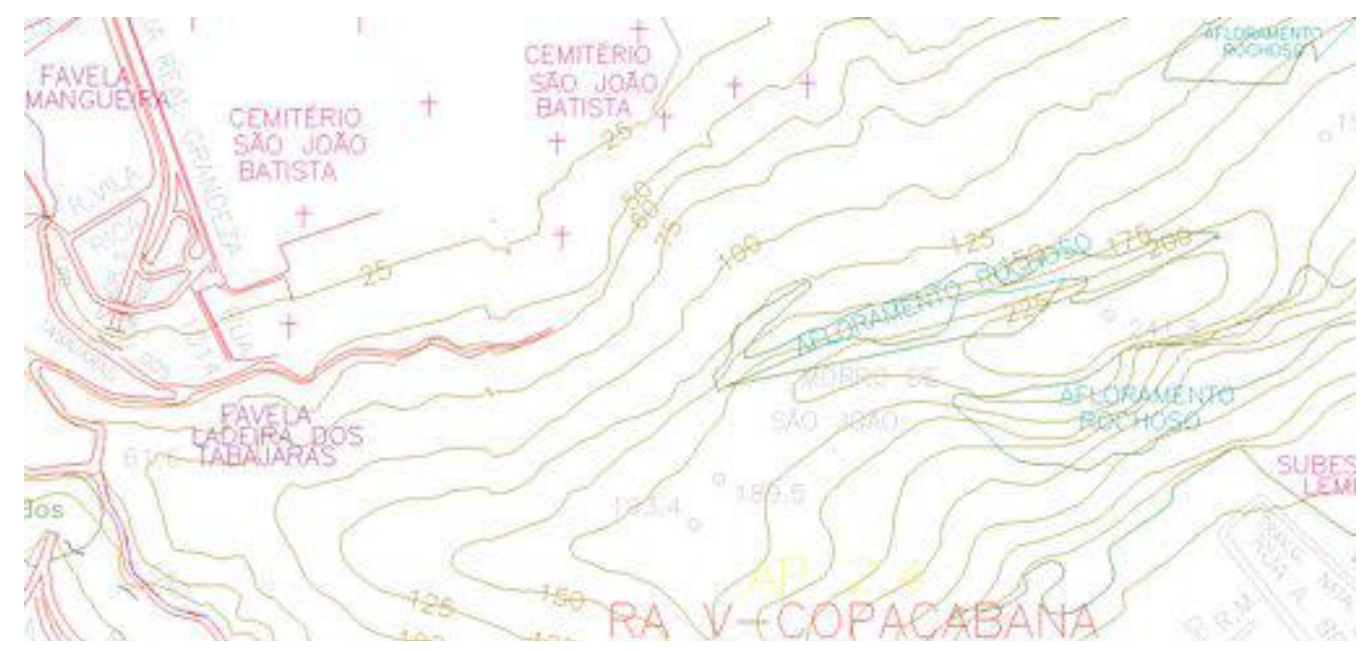

Fonte: Armazém de Dados da Prefeitura do Rio

\footnotetext{
${ }^{102}$ Disponível em: www.armazemdedados.rio.rj.gov.br
} 


\section{FIGURA 06 - Localização da Ladeira dos Tabajaras}

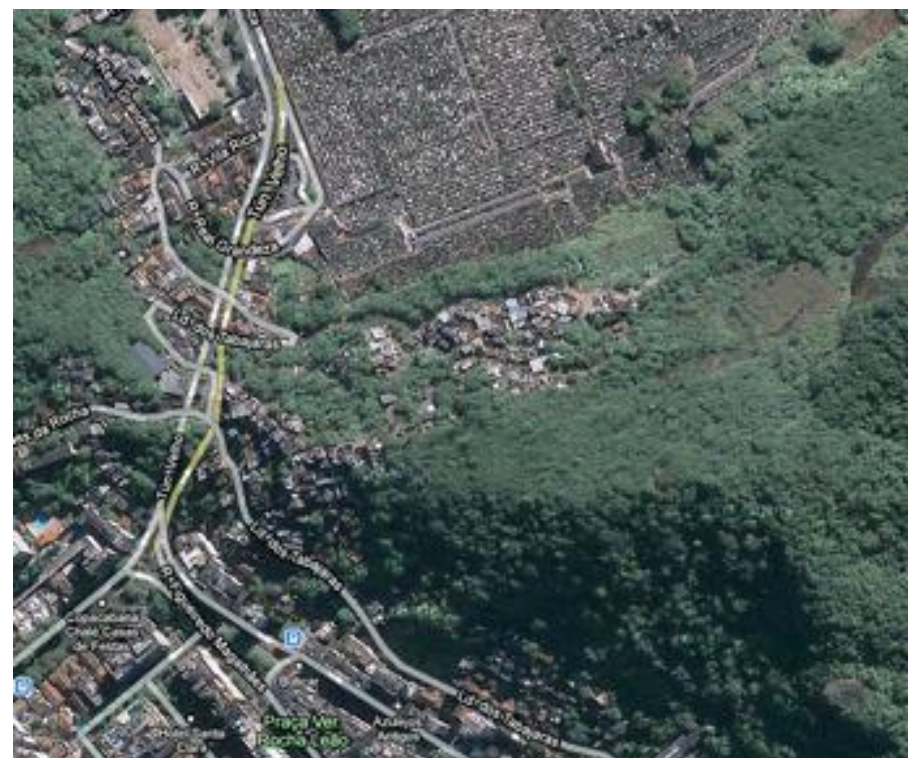

Fonte: Google Maps.

Tal informação será de extrema relevância para combater a alegação do poder munícipe sobre o conceito de área de risco. Os afloramentos rochosos e os depósitos de tálus ${ }^{103}$, os quais são considerados como perigosos, pois podem rolar a qualquer momento sobre as casas são identificados apenas no lado leste da comunidade e no limite sul, local onde existem 30 casas e não na comunidade inteira como afirma o Relatório da GEO-RIO.

Outra identificação muito importante trazida pelo relatório é que além das declividades médias do terreno não serem muito acentuadas, os trechos em escarpa rochosa, que estão mais próximo às residências, encontram-se pouco fraturados em quase toda a encosta, não oferecendo assim risco de desprendimento de lascas de pedras.

O relatório também identificou diversas obras de contenção realizadas pelos próprios moradores, nos cortes das encostas para as construções de casas, tendo seus muros de contenção muitas vezes

\footnotetext{
${ }^{103}$ Depósitos de rochas não consolidados (material incoerente e heterogêneo) são denominados tálus. Disponível em: http://talusnopantanal.blogspot.com.br/2012/10/o-que-etalus.html.
} 
embasados na rocha, diminuindo bastante o risco de desabamentos, como se pode perceber nas figuras abaixo:

FIGURA 07 - Obras de contenção na Ladeira dos Tabajaras

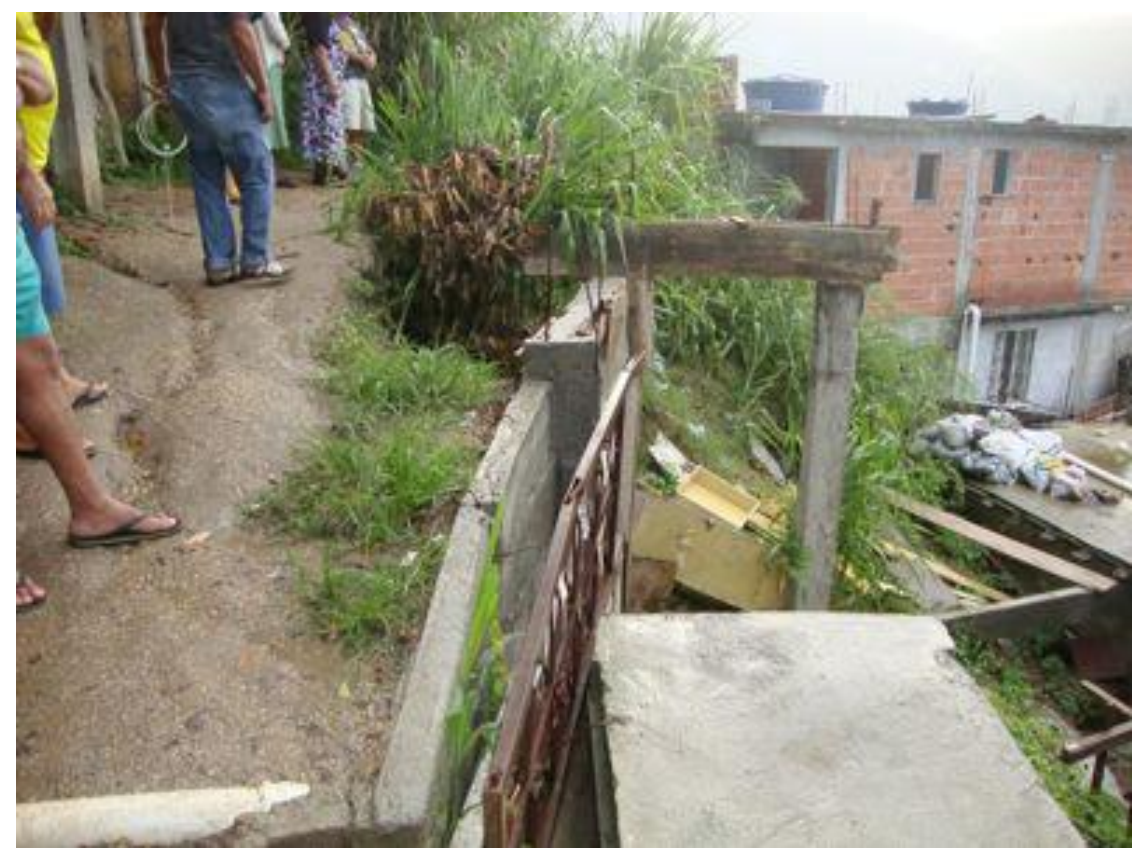

Fonte: Relatório da Estradinha (p.05).

\section{FIGURA 08 - Obras de contenção na Ladeira dos Tabajaras}

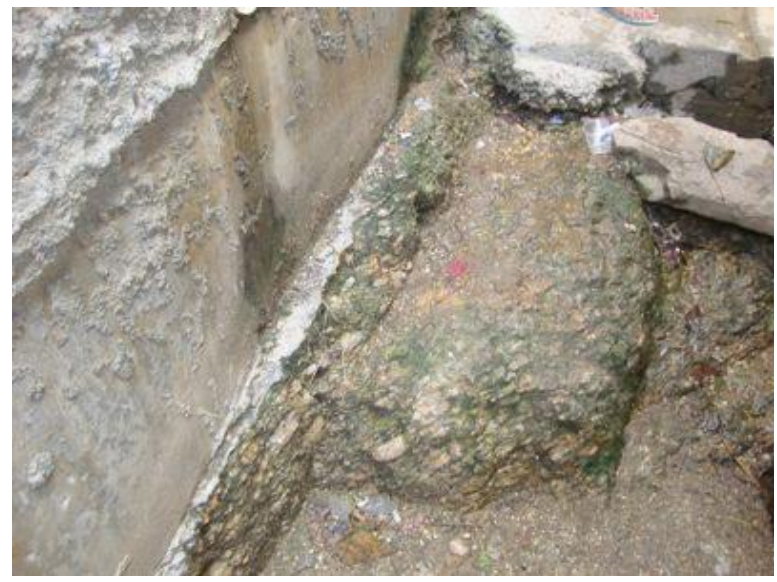

Fonte: Relatório da Estradinha (p.05).

É importante ressaltar neste momento as intervenções realizadas, em 1996, pelo Programa Favela-Bairro do Morro dos Cabritos. Este programa, apesar de deixar trechos de pavimentação de caminhos e drenagens inacabados, também teve várias obras de contenção bem executadas e que, 
segundo o relatório, permanecem íntegras. Há também obras de estabilização realizadas nas encostas, em contratos independentes do Favela-Bairro, localizadas na parte oeste da comunidade e que também evitam possíveis deslizamentos, conforme figuras 09 e 10.

\section{FOTO 09 - Obras de contenção na Ladeira dos Tabajaras (Programa Favela-Bairro)}

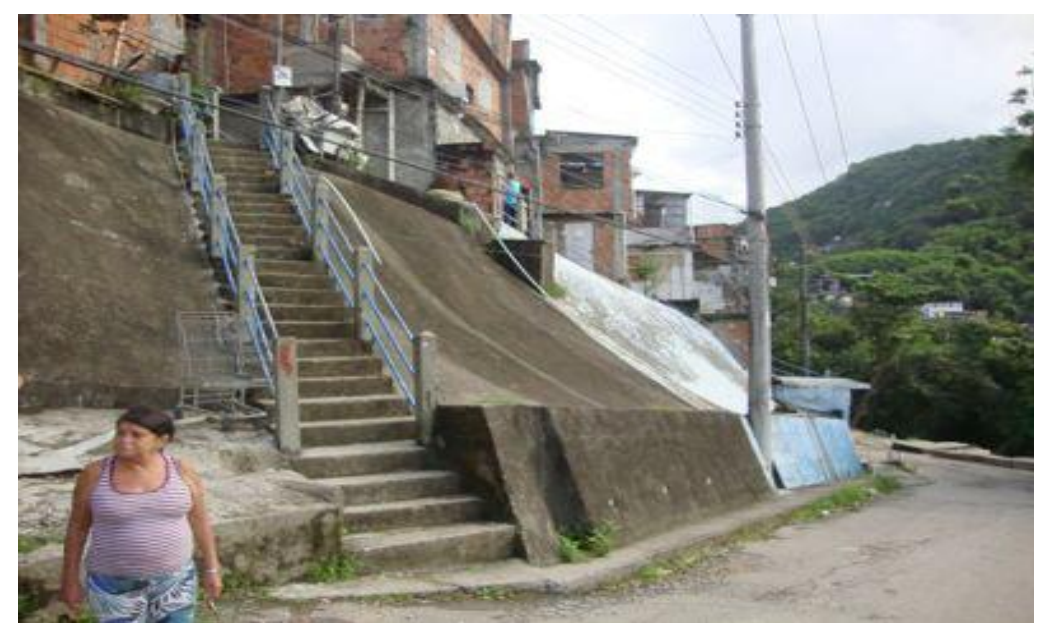

Fonte: Relatório da Estradinha (p.07).

\section{FIGURA 10 - Obras de contenção na Ladeira dos Tabajaras (Programa Favela-Bairro)}

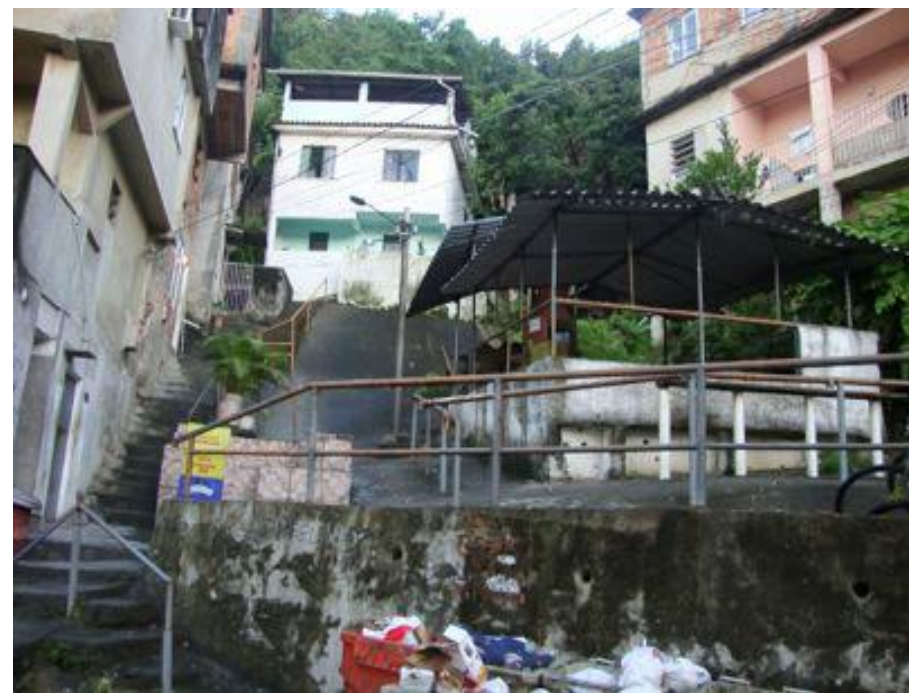

Fonte: Relatório da Estradinha (p.12).

A questão mais interessante relativa a apresentação deste relatório é que os cortes realizados no terreno pela administradora do cemitério São 
João Baptista (Santa Casa de Misericórdia), para abrir espaço para novas áreas de sepultamento são os fatores que trazem instabilidade à encosta. Inclusive, é exatamente o local no qual houve deslizamento de terra, tanto na década de 1980, quanto em abril de 2010, após a forte chuva, levando ao soterramento de sepulturas e outros danos materiais, conforme o relatório (figura 11).

\section{FIGURA 11 - Desabamento na Ladeira dos Tabajaras (Cemitério São João Batista)}

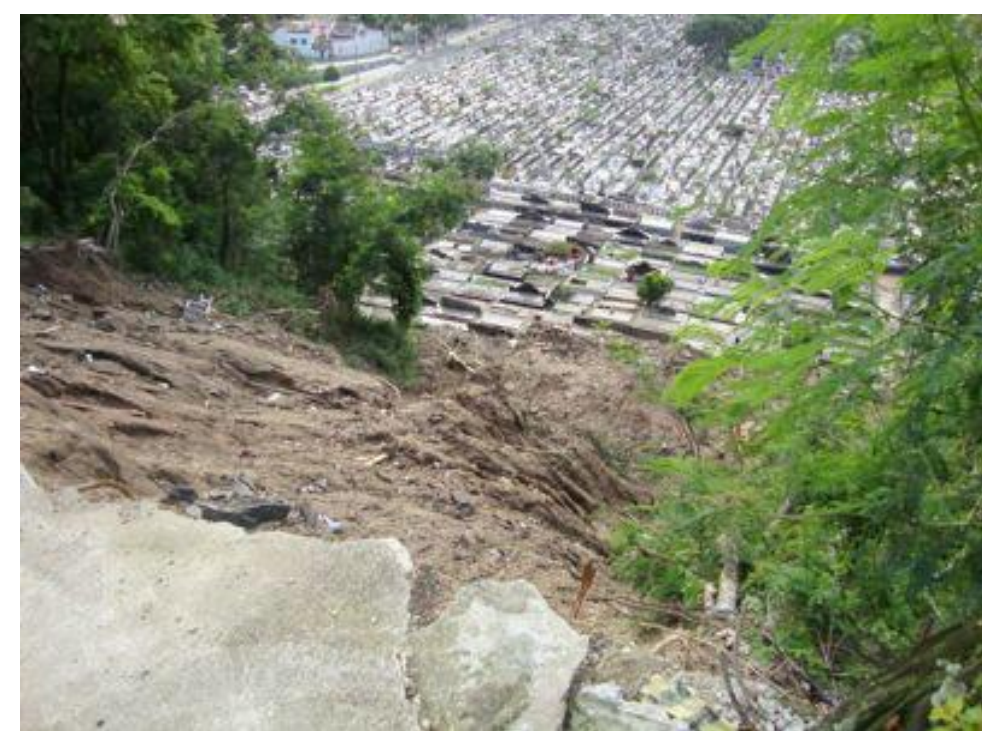

Fonte: Relatório da Estradinha (p.10).

Ainda que o deslizamento tenha provocado danos ao cemitério e à uma pequena parte da comunidade, ao levar parte da pavimentação e do meio-fio da rua e arrastar um automóvel, árvores e vegetação, não houve nenhum prejuízo em relação às edificações. Mesmo após os deslizamentos, as casas permaneceram afastadas da encosta e também nenhum tipo de rachadura foi identificado nelas, ou mesmo depressões no terreno adjacente. 
FIGURA 12 - Desabamento na Ladeira dos Tabajaras (Cemitério São João Batista)

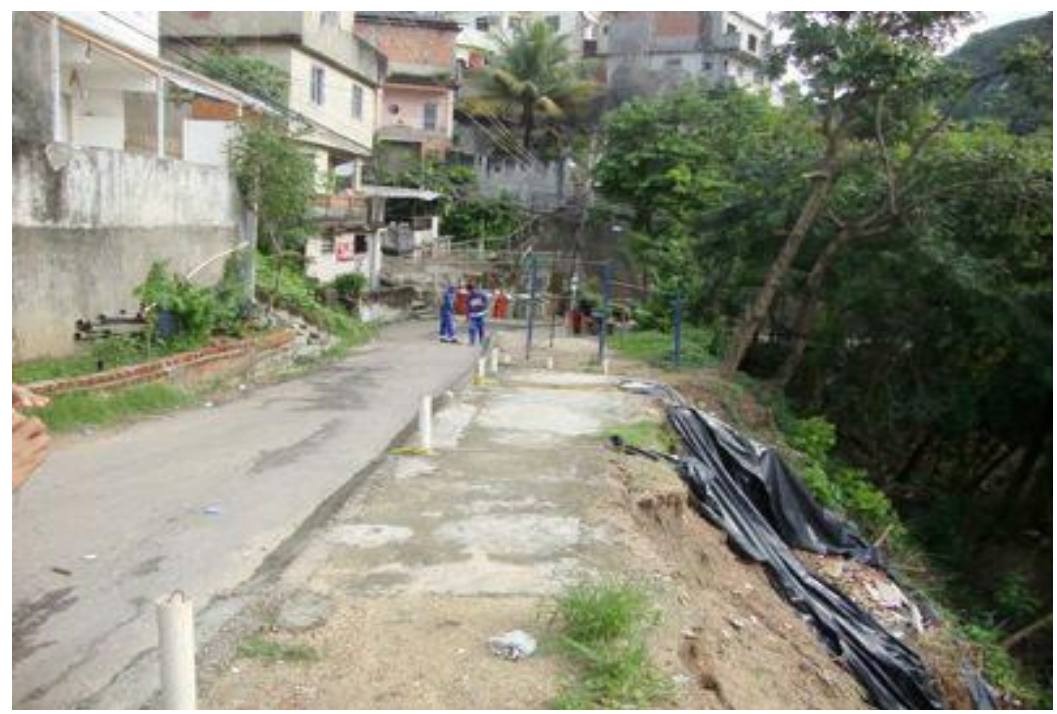

Fonte: Relatório da Estradinha (p. 11).

2) Considerações sobre o risco geológico-geotécnico na comunidade e sua avaliação pela GEO-RIO:

2.a) Os riscos identificados como moderados se encontram em apenas dois setores da comunidade: na área de depósitos de tálus - limite leste da comunidade, e nos taludes a jusante (abaixo) da rua de acesso e a montante (acima) do limite sul do cemitério, onde o risco é muito maior para o cemitério do que para as residências da comunidade. A solução encontrada pelo perito para a estabilização é simples e de baixo custo: desmonte dos blocos maiores ou com maior risco de rolagem $\mathrm{e}$ deslizamento e a execução de muros, preenchidos com pedras de mão obtidas pela própria demolição. Esse tipo de construção já foi utilizada para contenção de encostas em diversas localidade da cidade, como por exemplo, o Morro Dois Irmãos (Rocinha).

2.b) O Relatório da GEO-RIO afirma que somente a remoção total das casas será eficaz na prevenção de tragédias oriundas dos deslizamentos, pois as casas que estão situadas nos limites da comunidade, próximo ao depósito de tálus ou ao trecho de escarpas estão mais vulneráveis aos acidentes causados por movimentação das rochas. Porém, o relatório do Dr. 
Maurício confirma que a estabilização das encostas é o suficiente para reduzir significativamente possíveis desastres e que a remoção das casas é tecnicamente desnecessária.

2.c) No que tange à rua de acesso da comunidade, os taludes ${ }^{104}$ de alta declividade não apresentam riscos iminentes para as casas localizadas acima. No entanto, o risco maior de novos deslizamentos está localizado na área logo acima do cemitério, trazendo prejuízos e danos para o mesmo. Para evitar que a área do cemitério seja atingida, serão necessárias obras de maior porte e custo. Portanto, mais uma vez tem-se afastada a possibilidade de remoção tendo em vista que um possível deslizamento atingiria apenas a área do cemitério e não prejudicaria em nada a Estradinha.

2.d) Quanto aos custos das obras de contenções, o Relatório da GEORIO afirma que seria inviável a recuperação da área, devido ao seu alto valor, estimado em: $\mathrm{R} \$ 1.950 .000,00$ (um milhão e novecentos e cinquenta mil reais), sem incluir a demolição e a retirada de entulhos. O Parecer Técnico, no entanto, discorda deste posicionamento, avaliando que as demolições, juntamente com as indenizações das residências, considerando que a Prefeitura negociou com alguns moradores valores acima de R\$ 100.000,00 (cem mil reais), somando ainda a retirada dos entulhos da localidade, custaria um valor muito superior ao das obras de contenção indicadas no relatório.

Por fim, o Relatório do Coletivo Técnico, elaborado pelo Dr. Maurício conclui que não há nenhum fundamento técnico ou econômico na proposta de remoção elaborada pela Prefeitura. Esta, por sua vez promove demolições desnecessárias, ameaçando abalar as estruturas das residências vizinhas, principalmente em se tratando de casas geminadas. Além disso, o relatório aponta ainda para a questão referente aos entulhos das demolições que não são retirados pelo poder munícipe e causam prejuízos aos moradores.

\footnotetext{
${ }^{104}$ Talude pode ser definido como uma superfície inclinada que delimita um maciço terroso ou rochoso. DYMINSKI, Andrea Sell. Noções de Estabilidade de Taludes e Contenções. Disponível em: http://www.cesec.ufpr.br/docente/andrea/TC019/TC019/Taludes.pdf. Acessado 25/05/2013.
} 
Inclusive, há um laudo (ver em anexo) do engenheiro civil sanitarista Alexandre Pessoa, da FIOCRUZ, sobre uma vistoria técnica, solicitada pelos moradores da comunidade da Estradinha, avaliando os impactos dos entulhos deixados pela Prefeitura na localidade. Esse parecer aponta diversas irregularidades no ato das demolições que estão trazendo riscos à saúde dos moradores da Estradinha. São eles:

1) Falta de placas de identificação e delimitação das obras de demolição: não existem placas que informem o órgão executor e responsável técnico pela mesma, e não há delimitação das obras, que ocorrem de forma pulverizada na comunidade, trazendo assim diversos transtornos ${ }^{105}$;

2) Falta de barreiras de proteção nas habitações em demolição: a ausência de proteção (tapume, tela de proteção, etc) gera riscos de acidentes decorrentes do desprendimento de material durante a demolição, além de possibilitar a entrada de crianças em áreas que ocorreram as demolições, configurando assim, risco iminente;

3) Problemas nas vias de acesso de moradores: a falta de delimitação das obras tem espalhado entulhos nas vias de acessos, com concretos e vergalhões expostos, madeira, etc. O risco aumenta uma vez que os moradores não tem um local alternativo para chegar às suas residências, pois os entulhos comprometem a sua mobilidade, estreitando assim os caminhos. Além disso, há o perigo de se machucar nos materiais expostos;

4) Interferência sobre o sistema de drenagem pluvial: a não remoção dos entulhos pode obstruir o sistema de drenagem, formando pontos de alagamento e criando novos cursos de águas superficiais, gerando instabilidade no solo e das edificações existentes. Tal fator pode comprometer ainda os demais sistemas de água potável e esgotamento sanitário;

5)Entulho acumulado nas áreas que sofreram demolição: a acumulação do entulho, associado ao lixo, resulta na formação de criadouros de vetores transmissores de doenças, tais como ratos, baratas, mosquito da dengue, dentre outros;

6) Demolições realizadas muito próximas às moradias habitadas: as demolições ocorrem muito próximas às moradias, o que pode gerar acidentes e inclusive comprometer a estabilidade das habitações, como por exemplo a grande quantidade de casas geminadas no local;

\footnotetext{
105 No dia 25 de Agosto de 2010, o Conselho Regional de Engenharia e Arquitetura (CREA - RJ) realizou uma fiscalização das demolições na comunidade da Estradinha. Os fiscais verificaram a presença da empresa Hécio Gomes Engenharia Ltda, inscrita neste Conselho, contratada pela Prefeitura do Rio, executando as demolições e a retirada do entulho das casas demolidas, somando um total de 107 demolições. A empresa foi notificada por desobedecer aos requisitos das leis federais $n^{\circ}$ 6.496/77, por falta de Anotação de Responsabilidade Técnica - ART e $n^{\circ}$ 5.194/66, por falta de placa, as quais designam multa diante do não cumprimento das mesmas. Relatório Demolição - Ladeira dos Tabajaras (Botafogo). Ver anexo.
} 
7) Redes elétricas, áreas energizadas, próximas às demolições em curso: as redes de energia são eventualmente danificadas pelas demolições, o que pode causar curto-circuito e sinistro de incêndio;

8) Insegurança decorrente das obras de demolição: os transtornos causados pela remoção e os perigos existentes podem gerar stress, traumas e problemas psicológicos, em especial às crianças e idosos com problemas cardiovasculares.

De acordo com o parecer técnico do Dr. Alexandre Pessoa, compreende-se que os entulhos, deixados pela Prefeitura dentro da comunidade, é que situam os habitantes em área de risco. O que não deixa de ser uma estratégia para forçar os moradores a deixar o local e aceitar a proposta outrora realizada. Sobre esta questão dos entulhos, há uma ação judicial (ver em anexo), movida pelo NUTH, para forçar a Prefeitura a retirar os restos das demolições da comunidade. Embora a sentença tenha sido favorável à Estradinha e condenado o Município a uma multa considerável diante da não retirada dos materiais, o réu do processo iniciou o recolhimento de uma pequena parte, mas não concluiu o seu dever.

Portanto, somando às informações acima o diagnóstico do Dr. Maurício Campos, é possível concluir que a área concernente à Estradinha não se encontra em risco e que os pontos de vulnerabilidade do terreno podem ser solucionados com simples obras de contenção, não sendo necessária a remoção imposta pelo poder público. E, por conseguinte, já que comprovadamente os motivos alegados pela Prefeitura não encontram respaldo, resta a certeza de que o verdadeiro motivo para a remoção da comunidade da Estradinha é a extrema valorização do solo urbano, conhecida como especulação imobiliária.

Diante dessas considerações, no próximo capítulo serão apresentadas as mulheres que lideram o movimento de resistência da Estradinha, na luta pelo seu direito à permanência no local, suas estratégias para efetivar o direito à moradia adequada, ao cultivo das suas raízes e ao pertencimento à comunidade. 


\section{A Raça do Gênero? As Guerreiras da Estradinha e a luta pelo Direito à Moradia Adequada}

O Direito à Moradia dos habitantes de favelas do Rio de Janeiro é constantemente violado, através dos despejos forçados, em função da supervalorização do espaço urbano, principalmente nas áreas consideradas as mais nobres da cidade. No entanto, esta população oprimida tem se organizado, lutando pela permanência nessas localidades, elaborando diferentes estratégias para resistir ao arbítrio do poder público.

Assim, a partir das reflexões realizadas nos dois primeiros capítulos do presente trabalho, nossa atenção será voltada, a partir deste momento, para o processo de resistência, contra a remoção da comunidade da Estradinha. As mulheres, vitimizadas e vulnerabilizadas pelas remoções, reúnem forças, coletivamente, para defender seus lares, suas famílias e suas histórias. Por outro lado, se tornam protagonistas na luta contra a arbitrariedade exercida pelo poder público. A seguir, adentraremos o universo dessas mulheres que elaboram e articulam estratégias para defender o direito, constitucionalmente garantido, à moradia adequada.

\subsection{Quem são as guerreiras da Estradinha?}

A primeira vez que encontrei a Sra. Maria de Fátima Amorim, vicepresidente da Associação de Moradores da Ladeira dos Tabajaras - Lado Botafogo, conhecida como Irmã Fátima, participava de uma reunião, na qualidade de estagiária do NUTH, na comunidade Vila Autódromo, também ameaçada pela remoção. Fiquei bastante impressionada com o seu discurso, bem como a demonstração de sua liderança política. Após aquela ocasião, estive em contato com a comunidade da Estradinha, através dos atendimentos realizados nas instalações daquele núcleo da Defensoria Pública. 
Eu já havia percebido que a quantidade de mulheres, das diversas comunidades cariocas, a procurar o NUTH era bastante significativa, fato este que me despertou para investigar tal fenômeno. Decidi, então, observar aquele movimento de mulheres, que apesar de não se intitularem como "movimento de mulheres pela luta ao direito à moradia" estavam executando este papel.

Desta maneira, passei a analisar o desempenho da comunidade da Estradinha, que resistia bravamente às investidas arbitrárias da Prefeitura. Ainda que muitos moradores tenham se desesperado diante das ameaças de remoção e terminaram por aceitar a proposta de retirada do local, um grupo permaneceu na comunidade, negando-se à realocação em outra localidade. Portanto, ao aprofundar-me nos estudos sobre a comunidade e conhecer as pessoas que estão na linha de frente desta batalha, constatei que todas eram mulheres e que estavam determinadas a defender seus direitos.

$\mathrm{Na}$ primeira reunião da qual participei na comunidade, surpreendime com o perfil das pessoas participantes. Eram todas mulheres. Desde a liderança comunitária, representada pela Irmã Fátima, até as lideradas. Fiquei impressionada com a união do grupo e sua articulação. Sendo assim, expliquei, posteriormente à Irmã Fátima, que gostaria de estudar sobre o caso da Estradinha e falar sobre a luta feminina daquela localidade. Assim, obtive os contatos das mulheres da comunidade, por intermédio da sua principal articuladora e marquei entrevistas em suas próprias residências, com o objetivo de desvendar o universo das principais militantes da comunidade.

Tendo em vista que não seria possível entrevistar ${ }^{106}$ todo o grupo, selecionei cinco mulheres, incluindo a Irmã Fátima, utilizando o critério da participação ativa, o destaque na militância. Fui muito bem recebida por todas elas, que conscientes do papel que estavam desempenhando na comunidade, relataram suas histórias de luta e resistência. Dentre toda a

\footnotetext{
${ }^{106}$ As entrevistas estão transcritas integralmente no anexo da monografia.
} 
população feminina da Estradinha, essas mulheres representam muito bem a diversidade de perfis presente na comunidade: são mães, avós, bisavós, trabalhadoras assalariadas, donas de casa, afrodescendentes, casadas, viúvas, adultas, idosas, nordestinas, cariocas, etc., que afirmavam não ter nenhum ativismo político anterior ao movimento contra as remoções e se transformaram em guerreiras, militando no calor da batalha pela defesa do direito à moradia adequada. A seguir, conheceremos as histórias de vida e as visões de cada uma delas sobre a remoção.

\section{Dona Bené.}

A Sra. Benedita Veríssimo Dias, tem 82 anos, sendo a moradora militante mais idosa da Estradinha. Identifica-se racialmente como negra e seu estado civil é viúva. Estudou até o segundo ano do antigo primário e relata que mora na Ladeira dos Tabajaras há 72 anos e desse longo período, reside há 27 anos na Estradinha. Dona Bené, como é carinhosamente conhecida pela comunidade, criou seus filhos na Ladeira dos Tabajaras, lado Copacabana, onde pagou aluguel por mais de 40, e se mudou para a Estradinha em 1986, com a oportunidade de moradia própria concedida pelo Prefeito Saturnino Braga.

Dona Bené se emociona ao relembrar toda a sua história. Quando seu marido faleceu, ela ainda permaneceu morando na casa alugada com seus nove filhos até que a proprietária pediu a sua casa, pois sua filha iria se casar. Ela diz que não tinha para onde ir e então ao saber do grupo de moradores que estava se organizando pra legalizar os terrenos na Estradinha, se juntou a eles para pleitear um local de moradia próprio. Mudou-se com sua família pra Estradinha quando a casa ainda não tinha terminado e lá terminou de criar seus filhos. Portanto, Dona Bené afirma que os habitantes da Estradinha não são invasores e que resistirá pelo seu direito a permanecer em sua residência.

Sobre a questão da área de risco, diz que, em todos esses anos de vivência na Ladeira dos Tabajaras, nunca aconteceu nenhum desastre na 
área da Estradinha. Relembra vários outros acidentes com deslizamentos de terra em outras localidades do Tabajaras, os quais deixaram vítimas fatais e que, o único deslizamento que houve na Estradinha foi no local onde o "Favela-Bairro" não concluiu as obras e que fica exatamente na área pertencente ao cemitério São João Baptista, não afetando nenhuma moradia da comunidade.

Durante a entrevista ela diz que foi muito duro ver as pessoas em desespero por causa da remoção. Sofreu tanto ao saber que vizinhos venderam suas casas às pressas com medo de perdê-las, quanto ao ver as suas casas sendo derrubadas. No entanto, manteve-se firme na resistência, afirmando que o que ela preza não é o dinheiro e sim a moradia. Afirma que a sua moradia é adequada e que com ela ainda reside parte da família:

(...) eu vim pra cá e daqui eu não saio! Eu estou satisfeita porque a minha moradia é adequada! E nessa resistência nós vamos até o final e vamos resistir. Muitos que foram à Prefeitura pra saber o valor de suas casas, se engrandeceram com aquele pouco e eu até hoje não sei os valores. Eu pensei "pra onde que eu ia"? Agora não, que a metade dos filhos já casou. Mas, somos ainda três! Eu, minha filha mais velha e meu filho mais novo. Nós estamos aqui e vamos resistir! (emocionada).

Desta maneira, Dona Bené permanece firme na linha de frente da resistência, com seus oitenta e dois anos, ao lado de suas outras companheiras na luta pelo direito à moradia adequada. É com certeza muito respeitada por todos os moradores da Estradinha, não só pela sua experiência de vida como também pelo espírito de resistência estampado no seu rosto.

\section{Dona Carminha}

Esposa do comerciante conhecido como Sr. Marrom. A Sra. Maria do Carmo Brito Barreto tem setenta e três anos e se identifica como negra. Nascida em Santa Catarina, Dona Carminha veio para o Rio de Janeiro aos dezesseis anos, estudou até a quinta série do ensino fundamental e reside na Ladeira dos Tabajaras há cinquenta anos.

Antes de se instalar nesta comunidade, ela morou em outros lugares no subúrbio, como Madureira e Colégio. Mora na Estradinha desde a 
distribuição dos terrenos oficializada pelo Prefeito Saturnino Braga e relata que participaram de diversas reuniões à época do evento junto à associação de moradores. Inclusive, ressalta diversas vezes durante a entrevista que todo este processo de distribuição do terreno e construção das casas foi realizado numa ação conjunta com o poder munícipe e que, portanto, não podem ser considerados como invasores.

Dona Carminha se emociona alguns momentos relembrando os impactos trazidos pela remoção:

(...) Eu tive depressão, pressão alta e estou até hoje. A depressão, graças a Deus, estou conseguindo debater porque meus filhos lutam muito comigo, meus vizinhos também. Dizem "para com isso, não é assim!". Pressão alta e diabetes. Nem tudo eu posso comer, nem tudo eu posso beber... Eu vivo assim!

No trecho destacado acima, são identificados os problemas de saúde, decorrentes do stress causado pela remoção. Em seu depoimento, ela conta que alguns idosos não resistiram às consequências das demolições e da mudança para outros locais, o que levou à ocorrência de acidente vascular cerebral e posteriormente, à morte. Ainda assim, mesmo com todas as desventuras ocorridas, esta senhora adquire uma postura de resistência ao afirmar que não deixará a sua casa, nem a sua comunidade.

\section{Dona Anita}

Moradora da comunidade da Estradinha há 24 anos, a Sra. Anita Maria Ramos, tem cinquenta e sete anos, é casada e se identifica racialmente com a cor morena ${ }^{107}$. Estudou até a quarta série do ensino fundamental, é dona de casa e cuida dos netos enquanto seu genro e sua filha trabalham. Dona Anita é uma das moradoras mais antigas da comunidade e também chegou ao local junto ao grupo que recebeu os terrenos na gestão do Prefeito Saturnino Braga. Ela relata que na ocasião morava numa casa alugada de uma vila na Ladeira dos Tabajaras e que o prefeito havia liberado os terrenos para a população de baixa renda para a

${ }^{107}$ É importante ressaltar que não existe esta categoria de cor/raça, segundo os critérios de análise do IBGE. Apenas transcrevi como a entrevistada se identifica racialmente. 
construção de residências, justamente com o objetivo de tirar aquelas pessoas da situação de pagamento de aluguel.

Dona Anita demonstra que entende bem o conceito de moradia adequada, afirmando que deve ser localizada próxima a equipamentos e serviços públicos, tais como acesso ao trabalho, educação, saúde e meios de transporte, etc., como destaca o trecho abaixo:

(..) eu acho que a pessoa que luta para ter uma moradia, não quer perdê-la, ainda por cima aqui na zona sul. A gente vai pra onde? Pra um lugar onde tudo é longe? Porque lá embaixo tudo é difícil. Quem mora longe é mais complicado pra descer pra trabalhar, pra médico, pra se locomover, pra tudo... Tem muita gente que saiu daqui e se arrependeu. Foram morar em Campo Grande, Santa Cruz, etc. E agora estão arrependidos de ter saído. Porque se não tivessem saído, estaria todo mundo em sua casinha direitinha. Mas, resolveram vender porque o dinheiro falou mais alto... Pra mim, isso não me interessa não, interessa é a minha moradia. E aqui fica tudo mais perto, o trabalho deles, a escola dos meus netos, o médico. Eu não tenho interesse nenhum de sair daqui!

Ela conta que os agentes da Prefeitura chegaram à comunidade se passando por agentes censitários do IBGE e que não estava em casa quando a sua residência foi fotografada, medida e marcada com a numeração da SMH. Apenas recebeu a notícia de que a sua habitação constava numa lista dos imóveis que seriam removidos, com o valor correspondente. Ressalta, ainda, que o Município avaliou a sua casa no valor de $\mathrm{R} \$ 80.000,00$ (oitenta mil reais) e que com o valor oferecido não é possível comprar nem uma quitinete próxima à comunidade:

Ofereceram $\mathrm{R} \$ 80.500,00$. Mas, eu não tenho interesse em vender! Porque eram sete pessoas que moravam aqui dentro. Eles vão querer me levar pra onde? Pra uma casinha de pombo? A minha casa tem 132 metros quadrados, toda construída, com terraço, primeiro e segundo andar. O que eu vou comprar com $\mathrm{R} \$ 80.000,00$ reais na zona sul? Com esse valor eu não compro nem uma quitinete.

Desta forma, Dona Anita continua lutando, com suas companheiras, pelo direito à moradia adequada e não se interessa em vender sua casa por qualquer oferta proveniente da Prefeitura, sempre repetindo que o dinheiro não importa e o que de fato a interessa é a sua moradia para abrigar toda a sua família de forma digna.

\section{Dona Marli}


Conhecida pela comunidade como Dona Marli, a Sra. Antônia Souza Alves, tem 61 (sessenta e um) anos, não se casou, mas vive em regime de união estável e se considera, racialmente, como parda. Com muito bom humor, explica a questão complexa referente aos seus dois nomes, dizendo que sua mãe desejava que seu nome fosse Antônia Marli e que seu pai estava alcoolizado ao realizar o registro e, portanto, registrou apenas o primeiro nome. Ela relata que nunca estudou e que nasceu numa cidade próxima a Sobral, no Ceará e veio morar no Rio de Janeiro com uma irmã permanecendo até hoje.

Dona Marli mora na Estradinha há 27 (vinte e sete) anos junto com seu companheiro, seus dois filhos e sua neta. Conta que todos os moradores foram cadastrados na Prefeitura à época da distribuição dos terrenos e que o material para a construção das residências foi cedido pelo próprio Município. Reforça o fato de que não houve invasão e que tudo foi realizado de forma legal e que os documentos podem comprovar.

Com muita simplicidade, ela resume o conceito de moradia adequada dizendo que, é um lugar pra viver que tenha muitas melhorias como fazer encostas, retirar os entulhos, coleta de lixo, a construção de um caminho seguro, saneamento básico, escolas, postos de saúde e uma boa praça para as crianças brincarem e os idosos tomarem sol e se divertirem.

Relata, ainda, a situação de abandono em que vive a Estradinha, afirmando que nenhum político se interessa pelo bem-estar dos moradores, aparecendo na área apenas na época das eleições. Fazem variadas promessas, mas depois de eleitos não retornam para ajudar a comunidade em nenhum aspecto.

Com a chegada da remoção, houve a demolição das casas, o que prejudicou muito a comunidade, principalmente os que resistiram. Ela conta que as demolições foram realizadas de qualquer jeito, sem preservar a estrutura que havia no entorno. $\mathrm{O}$ acesso à sua casa ficou muito restrito, pois o caminho construído da rua principal até a sua residência e que 
inclusive foi pago por ela e pelos seus vizinhos, foi destruído pelos agentes de demolição da Prefeitura:

(...) Nós moradores nos reunimos... Eu dei cinquenta reais pro seu Maurício, que morava na época aqui embaixo, pra fazer o caminho. Eu paguei o material, porque se eu fosse pagar a mão de obra, eu não poderia. Uma vizinha deu o saco de cimento, outro deu areia, outro deu pedra e o caminho ficou muito bom. Aí, quando o pessoal vendeu as casas, eles quebraram as casas e nosso o caminho. Acabaram com o nosso caminho Meu dinheiro foi para o esgoto, pra vala. Entrei no prejuízo.

(...) Agora a gente vive no meio das ratazanas, das baratas, gambá, morcegos... Nada disso tinha aqui! Minha casa está cercada pelos entulhos . Está cheio de lixo aqui atrás da minha casa... Lixo trazido pelo vento, pelas chuvas e fica tudo acumulado nos entulhos. E ainda tem a dengue, porque acumula água nos lixos e eu que tenho que limpar. Tem muita ratazana que pula pra cá, barata e muita lacraia. Já matei cada lacraia enorme aqui dentro de casa. Mas, não tinha! Depois que a Prefeitura fez essa desordem aqui na Estradinha, aconteceu isso!

Assim, Dona Marli conclui que a comunidade nunca esteve em área de risco, e que se hoje a Estradinha está em área de risco, quem a colocou nesta situação foi a Prefeitura, ao deixar os entulhos no local, que por sua vez provoca o surgimento de animais nocivos à saúde. Afirma que jamais sairá da comunidade para outro local, porque aqueles que venderam suas casas se arrependeram e inclusive, muitos passaram a morar novamente em residências alugadas, pois não conseguiram comprar outra casa com o valor pago pelo poder munícipe.

\section{Irmã Fátima}

Vice-presidente da Associação de Moradores da Ladeira dos Tabajaras, a Sra. Maria de Fátima Amorim tem cinquenta e dois anos e é a principal articuladora da comunidade. Casada, mãe de cinco filhos, é conhecida na Estradinha como Irmã Fátima e identifica-se racialmente pela cor negra.

Ela conta que antes das remoções era apenas uma dona de casa, que não se envolvia com as questões da comunidade e definiu sua antiga rotina como alienada. Porém, quando o desespero bateu à porta dos moradores da comunidade, por causa do despejo forçado, ao ver o sofrimento de todos, decidiu que teria que fazer alguma coisa para ajudar os seus vizinhos. 
Desta maneira, começou a participar das reuniões junto com a Associação de Moradores e durante o processo de resistência acabou assumindo a posição de vice-presidente da associação comunitária. A Irmã Fátima demonstra sua sabedoria na condução de sua função, tanto na participação ativa junto aos movimentos sociais e aos órgãos de defesa da população como a Defensoria Pública e o Ministério Público, quanto na articulação de ações da sua comunidade, as quais contribuem de forma significativa para a união do grupo.

A Irmã Fátima diz que a sua moradia é adequada, pois a construiu com bases sólidas, com estrutura suficiente para construir mais de dois andares acima. Também afirma que a comunidade está próxima aos equipamentos públicos e que essa estrutura facilita bastante a vida de seus moradores. Portanto, analisa que a realocação em área distante trará prejuízos para os habitantes, considerando a ausência de estrutura dos locais indicados pela Prefeitura.

Há uma frase marcante dita por esta liderança e que representa a o pensamento da comunidade da Estradinha: "Eu quero ter voz! Quero ser ouvida e ter nossos direitos respeitados"! Assim, a comunidade continua de pé, lutando bravamente pelo seu direito à moradia adequada e resistindo às remoções forçadas.

No próximo item, veremos como essas guerreiras estruturam e executam as suas estratégias de defesa e se posicionam diante das políticas de remoção instituídas pela Prefeitura.

\subsection{Guerreiras não tem medo de ameaça: a luta contra as remoções}

Apesar de todo o transtorno trazido para a Estradinha através do despejo forçado, o sentimento de injustiça criou nos seus moradores um foco de resistência. A luta pelo direito à moradia adequada se fortifica a cada dia, não só através da permanência no local, como também através do 
discurso e da articulação com a Defensoria Pública, Ministério Público e grupos de outras comunidades atingidas pelas remoções.

É importante ressaltar que o protagonismo feminino é perceptível nas reuniões que ocorrem dentro e fora da comunidade. Sendo assim, as mulheres comparecem nos espaços de discussão em número muito maior do que os homens e buscam defender seus direitos. Muitas vezes, seus companheiros ou maridos estão trabalhando no horário dos encontros e são elas que comparecem em grande número para representar as suas famílias.

Assim, é possível perceber essa articulação na fala das moradoras entrevistadas quando questiono de que forma exercem essa resistência:

Vocês tem algum envolvimento político dentro da comunidade? Em relação à resistência?Como vocês se posicionam dentro da comunidade?

Bené: Tivemos-nos aqui o apoio do Dr. Maurício (engenheiro), do Dr. Marcos (arquiteto), da Dra. Maria Lúcia (defensora pública) e da Dra. Adriana (defensora pública), o Dr. Leonardo Chaves (procurador do Ministério Público) também esteve aqui no socorro da gente! Teve aqui também o Marcelo Itagiba (político), e foi com ele que conseguimos os documentos da posse registrada, não é o definitivo, mas já demos entrada no cartório.

Irmã Fátima: Nós buscamos a assistência jurídica junto à Defensoria Pública, ao Ministério Público e até mesmo a Anistia Internacional visitou a comunidade para averiguar o que estava acontecendo aqui. E também os professores e estudantes universitários também estão contribuindo conosco.

De que forma vocês exercem essa resistência?

Carminha: Indo às reuniões. Quando a Fátima aciona, nós vamos para representar a nossa Estradinha. O lugar que a gente mais vai é na Defensoria Pública. Marcou a reunião nós vamos. Quando não pode ir todo mundo, vão seis, três ou quatro, mas a gente está sempre representando a nossa Estradinha.

Anita: Eu deixava as crianças no colégio e ficava com a tarde livre, então acompanhava os moradores nas reuniões. Eu já fui com outras pessoas em várias reuniões, na Câmara dos Vereadores, Câmara dos Deputados (leia-se Assembleia Legislativa), $\mathrm{OAB}$, em tudo o que você puder imaginar nós fomos.

Desta maneira, identifica-se a quantidade de instituições acionadas pelos moradores e suas lideranças para tentar resolver o problema da comunidade. E, por conseguinte, através de uma comissão formada por seus habitantes, a Estradinha consegue pressionar o poder público e estabelecer um diálogo. É interessante perceber esta estratégia, posto que a Irmã Fátima 
raramente comparece a uma reunião sem a presença desta comissão, principalmente nos compromissos decisivos para o destino da comunidade.

Além de todos os infortúnios ocorridos, durante a época da remoção daqueles que aceitaram a proposta do Município para se retirar do local, houve contínuas ameaças por parte dos agentes da Prefeitura em relação ao grupo que permaneceu resistindo. Contudo, a coragem de permanecer no local sobrepõe o medo e aparece na forma de enfrentamento, como podemos ver no diálogo contado por Dona Carminha:

(...) Teve um dia, eu estava varrendo na porta da birosca, meu marido estava debruçado ali naquela porta e apareceu um dos empregados dele (agente da prefeitura), então eu perguntei pra ele: $\mathrm{O}$ que vai ser feito com o grupo de resistência? Aí, ele me perguntou: A senhora é uma das cabeças? Eu disse: Não, mas agora o grupo é razoável e com o mesmo pensamento! Então, ele perguntou qual era o pensamento. Eu disse: É de não sair daqui! Aí, ele disse pra mim: Se a senhora não quiser sair realmente da sua casa, a sua mobília vai ficar ali na rua, e a retro escavadeira vai derrubar a sua casa! Eu disse: Vai derrubar com todos dentro, porque ninguém vai sair! Isso eu falei chorando! Ele me disse: "a senhora disse que não vai sair... a gente vai fazer o que?" Eu disse: "É... Vocês são mais do que Deus, né? Porque pra mim, acima de vocês, está Deus! Agora, eu vou dizer pra vocês, vai ser meio difícil porque agora até bisneta eu já tenho dentro dessa casa e então ela vai ficar de mãos dadas, todos juntos ficaremos de mãos dadas e a escavadeira vai vir e nos matar". Eu não vou sair daqui com as minhas pernas não! Eu posso sair daqui sim... só se for em cima de uma maca, porque andando com as minhas pernas eu não vou não! Quando ele me falou isso... Foi uma punhalada! Eu disse pra ele: "Eu podia até te processar, porque você está fazendo ameaça para dois velhos". Ele tem 80 e eu 70! Naquela época... Agora ele já tem $83 . .$. Eu vou dormir à noite preocupada! Eu não sei se vou continuar aqui... A corda sempre rompe do lado mais fraco! (...)

O depoimento acima demonstra a pressão exercida pelo poder público, através de seus agentes, e a forma desrespeitosa com que se dirigiu à moradora. Além disso, tal ação mostra, mais uma vez, que todo o procedimento não observa os tratados e convenções de direitos humanos e principalmente à efetivação do direito à moradia. Este relato expõe a preocupação da Dona Carminha com as inúmeras investidas arbitrárias do Município, que por sua vez, desrespeita até a sua condição de idosa e, por outro lado, a força de resistir até às últimas consequências por um direito adquirido de forma legítima.

Outra estratégia utilizada pela comunidade é a participação nos fóruns de discussão, por meio dos quais entram em contato com as outras 
comunidades que estão enfrentando o mesmo problema. Nesses espaços, além de contarem sobre as suas experiências, elas aprendem com os exemplos das outras comunidades e retornam para a Estradinha com outra visão:

Vocês já tiveram contato com pessoas de outras comunidades que estão passando pelo mesmo problema?

Bené: Já, o pessoal da Favela do Metrô. Eu fui lá com uma comissão daqui, fomos dar um reforço, porque lá o trabalho deles é diferente do nosso, porque nós não somos invasores, mas, lá alguns invadiram. E lá, querem tirar pra fazer garagem pro Maracanã. A irmã Fátima não pôde ir e eu fui representando o Tabajaras. Fomos também ao Laboriaux, na Rocinha!

Vocês acham que eles utilizam as mesmas estratégias que vocês usam para a resistência?

Carminha: Nós fomos lá e achamos muito parados... Por mais que nós falássemos pra eles que tinham que lutar, se unir. Mas, eu achei muito parado e também muito distantes um do outro. Eles não têm aquela harmonia e união como a gente tem aqui.

Bené: (...) Nós fizemos manifestações no fórum, duas vezes. Levamos, para representar o desespero, os saquinhos com os entulhos... e lá tivemos um pouco de apoio. Vamos continuar lutando!

Irmã Fátima: A principal arma desta comunidade é a união. O fato de nós permanecermos unidos é que nos mantêm na resistência. Quando ocorre qualquer ameaça, toda a comunidade se mobiliza para enfrentar o problema. Já fizemos manifestações no centro da cidade e também quando os agentes da prefeitura aparecem. A nossa união é a melhor defesa.

Tal iniciativa permite a reflexão dessas mulheres sobre suas ações e estratégias utilizadas nos conflitos com a Prefeitura e até mesmo estabelecer uma comparação com o modo de proceder das outras lideranças de favelas. Assim, o diálogo com experiências diversas enriquece suas concepções e, por conseguinte, sua atuação política, contribuindo para o fortalecimento da resistência.

Paralelamente a todos esses esforços, caminham a informação e a conscientização sobre seus direitos. Esse fator constitui uma importante estratégia para os habitantes da Estradinha, pois quanto mais esclarecimentos possuírem sobre o direito à moradia adequada, não aceitam as propostas apresentadas, sem antes questionar o Município. Desta 
maneira, o conhecimento jurídico transmitido através do NUTH, por exemplo, orienta a comunidade no processo de remoção:

Anita: Eu acho que a gente não saiu daqui até hoje por casa da Defensoria Pública, que interferiu e está trabalhando muito em cima disso. Inclusive a gente ganhou aquela questão da retirada dos entulhos e que ia gerar multa. Vieram (agentes da Prefeitura), fingiram que estavam limpando, não tiraram quase nada e ficou por isso mesmo! Mas, a Defensoria Pública nos ajudou muito e continua nos ajudando! E também a comunidade... O Reinaldo, presidente da associação de moradores e a Irmã Fátima, a vice-presidente, que vão às reuniões, correm atrás, as pessoas vem ver as coisas que aconteceram aqui, os engenheiros, por causa do conhecimento deles!

Bené: O meu pensamento é positivo, agora eu sou consciente de que não temos nenhum político para nos apoiar. Se não fosse esse grupo de resistência não estaríamos todos aqui enfrentando essa situação. Aqui é um laço onde nós temos tudo! A nossa criação toda foi aqui! Só que por mais forte que você seja, tem hora que você fracassa. Eu ainda não entreguei os pontos... Nós vamos lutar! Meus filhos às vezes me perguntam, quando tem reunião: "o que a senhora vai fazer lá"? Eu digo: "eu vou porque palavras o vento leva, mas só vale o que está escrito"! Mesmo que eu não entenda o que está acontecendo, mas eu estou ouvindo! Toda vez que tem reunião com a irmã Fátima e os defensores, eu largo tudo que estou fazendo e vou pra reunião! O coração e a cabeça estão firmes! Tudo que está vindo de bom pra gente, a gente aceita! Quando começou isso (remoção) aqui pra gente, foi um desespero muito grande!Mas, eu não fraquejei, não!

\section{Qual o principal motivo para resistir à remoção?}

Marli: Porque eu não tenho condições de morar em outro lugar, e porque meu trabalha ficaria muito longe, e eu não teria como pagar a condução para ir trabalhar, chego ao trabalho às quinze para as sete morando aqui, se eu fosse morar em outro lugar teria que acordar às 3 da manhã.

Carminha: O meu principal motivo é ter que sair daqui pra morar longe. Minha bisneta estuda numa creche aqui, meus filhos, netos, todos trabalham aqui! Se eu tiver que ir morar na baixada, olha o transtorno que vai ser! Sair da minha casa, pra morar numa gaiola? Porque o que ele está dando é uma gaiola (apartamentos oferecidos pela Prefeitura)!

De acordo com os relatos acima, é possível compreender que a consciência de direitos é fundamental para mobilizar a comunidade. Mesmo com todas as ameaças de despejo forçado, o conhecimento afasta o medo e possibilita um diálogo entre a favela e o poder público, além de fomentar o exercício da resistência, que aparece como principal ferramenta de luta.

Isso enfatiza a percepção dessas mulheres enquanto sujeito político, contribuindo de forma crucial para o seu empoderamento, enquanto membros da comunidade. Desta forma, de simples donas de casa, elas se 
transformaram em militantes, ativistas, dialogando com autoridades e exigindo que as suas demandas sejam ouvidas e respeitadas. Considerando as perspectivas da teoria da interseccionalidade, a luta por direitos, através da resistência, retira essas mulheres da invisibilidade e realiza uma migração do status de vítima para protagonista de sua própria história.

A seguir, abordaremos o caso da Estradinha, à luz da teoria da interseccionalidade, apontando os principais aspectos da luta pela manutenção da comunidade no local e também como a invisibilidade de determinados fatores discriminatórios podem contribuir para o enfraquecimento do movimento de resistência.

\subsection{Um longo caminho a percorrer: A Estradinha construída na raça pela liderança feminina}

Dentro do cenário atual das remoções que atingem as favelas da cidade do Rio de Janeiro, a Estradinha 1014 aparece como um forte exemplo de resistência, combatendo através de estratégias de articulação internas e externas as ações arbitrárias do poder munícipe. Sendo assim, cerca de 100 famílias lutam pelo direito à moradia adequada e neste processo destaca-se o contingente feminino, cuja participação é bastante significativa.

$\mathrm{O}$ interessante é perceber que essas mulheres, que combatem ativamente, não percebem ainda alguns fatores discriminatórios que as vulnerabiliza, como por exemplo, as questões raciais e as de gênero. Portanto, ao realizar as entrevistas, identifico uma questão fundamental para esta análise: a existência de uma problemática na percepção da sua identidade racial. Como veremos no trecho abaixo:

Como a senhora se identifica racialmente? Cor ou raça que identifica?

Anita: Morena.

Bené: Eu sou da negritude Junior... (risos). Sou negra! 
Carminha: (...) Bem, eu digo que eu sou negra, que deixei de ser branca pra ser negra. Porque escura esses negócios não se usam mais, né? Então, ou é branco ou é negro. Então, eu digo que sou negra.

Marli: Bom, branca eu não sou, me considero parda.

Irmã Fátima: Sou negra.

$\mathrm{O}$ fato de ter dificuldade para se identificar como afrodescendente pode acarretar na invisibilidade de ações discriminatórias, como a segregação racial no espaço urbano ${ }^{108}$, na qual os brancos habitam a parte nobre e a população negra vive nos subúrbios, favelas e periferias, onde a dinâmica da cidade não oferece abundância de equipamentos e recursos públicos. Dessa forma, não percebem o racismo inserido na questão do direito à moradia:

No inicio da entrevista vocês se identificaram racialmente como não brancas. Eu queria saber se vocês acham que o fator racial tem alguma influência nessa questão da remoção?

Bené: Não.

Carminha: Eu também acho que não, porque em nenhum lugar e nem em momento algum alguém citou isso pra nós. Aqui também tem muitos brancos, muitos nordestinos. (...)

Anita: Eu acredito que não. Eu acho que o prefeito, na verdade, o interesse dele em tirar a gente daqui, é por causa do terreno para investir em alguma coisa para ganhar dinheiro.

Marli: Eu acho que não. Ele (o prefeito) quer é vender a Estradinha pra trazer os gringos pra turismo.

Em suas falas, observa-se apenas a referência à discriminação em relação à classe social e geográfica, ou seja, a pobreza e a favela. Não estão atentas ao fato de que "os espaços urbanos, criados por atos locais de

\footnotetext{
${ }^{108}$ O lugar natural do grupo branco dominante são moradias amplas, espaçosas, situadas nos mais belos recantos da cidade ou do campo e devidamente protegidas por diferentes tipos de policiamento: desde os antigos feitores, capitães do mato, capangas, etc., até a polícia formalmente constituída. Desde a casa grande e do sobrado, aos belos edifícios e residências atuais, o critério tem sido o mesmo. Já o lugar natural do negro é o oposto, evidentemente: da senzala às favelas, cortiços, porões, invasões, alagados e conjuntos "habitacionais" (cujos modelos são os guetos dos países desenvolvidos) dos dias de hoje, o critério tem sito simetricamente o mesmo: a divisão racial do espaço. GONZALEZ, Lélia e HASENBALG, Carlos. Lugar de Negro. Rio de Janeiro, Marco Zero, 1982, p. 15.
} 
eliminação de favelas e segregação forçada, são as manifestações espacialmente marcadas da marginalização de raça, gênero e classe ${ }^{109 "}$.

Embora haja um grande ativismo dessas mulheres afrodescendentes, elas ainda não se percebem/identificam como um grupo racial e feminino, o qual é vulnerabilizado pelas políticas locais de remoção. Considero importante que as guerreiras da Estradinha percebam que a identidade de racial e de gênero são importantes para elaborar estratégias de resistência articuladas às políticas públicas de combate à discriminação racial e de gênero.. A racialidade generada dos espaços urbanos, termo utilizado pela autora Keisha-Khan Perry para tratar da racialização do gênero, que tem sido silenciada nos discursos sobre terra e localização espacial ${ }^{110}$, o que tende à invisibilidade dessas mulheres, considerando a perspectiva trazida pela teoria da interseccionalidade.

Desta maneira, é muito importante que as militantes e ativistas estejam atentas para essa diversidade de discriminações que interagem, e que por sua vez, atinge-as, de forma direta e violenta, afetando o seu direito à moradia. Nesse sentido, é interessante destacar as observações realizadas por Keisha-Khan Perry:

A liderança de mulheres negras nas lutas urbanas por terra constitui um aspecto crucial na mobilização afro-brasileira contra o racismo e pelo acesso coletivo a recursos. O estudo de James Holston (1991, p. 696) sobre usurpação de terra na periferia urbana de São Paulo embasa a noção da terra como ferramenta usada estrategicamente por grupos urbanos na promoção de unidade política. Holston argumenta que os direitos territoriais para as(os) pobres urbanos estão enraizados nas fundações históricas do colonialismo, pelas quais elites econômicas têm mantido privilégio legal e extralegal para aquisição de terra. Recentemente, movimentos sociais de base que se opõem a essa forma de "hegemonia local" expandem "a ideia do direito de ter direitos legais" dentro do sistema jurídico brasileiro. (p. 722). Embora o trabalho de Holston ausente uma análise racial da resistência nos domínios públicos dos direitos, especialmente os direitos de propriedade, ele nos lembra do relacionamento histórico entre colonialismo e racismo, e das reivindicações atuais por terra que fazem as pessoas negras urbanas. Além disso, esse debate sobre disputas territoriais, coesão política e resistência exemplifica uma estratégia fundamental na luta por poder, justiça e

\footnotetext{
${ }^{109}$ PERRY, Keisha-Khan Y. Espaço urbano e memória coletiva: O conhecimento de mulheres negras em lutas políticas. IN: SANTOS, Renato Emerson dos (Org.). Questões Urbanas e Racismo. Petrópolis-RJ, 2012. Ed. De Petrus e Alii Editora. p. 170.

${ }^{110}$ Ibid. p. 170.
} 
ampliação de acesso a recursos materiais empreendidas pelas comunidades negras urbanas ${ }^{111}$.

Em vista disso, o resgate da identidade traz outro benefício, quando "centraliza a participação das mulheres negras nessas lutas de base e promove a articulação de conhecimento, consciência e resistência racial aos

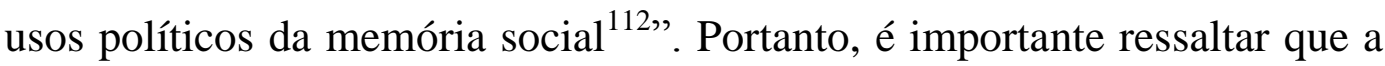
construção identitária desta comunidade é fundamental, tanto para trazer visibilidade a este grupo específico, quanto para se apropriar de outras ferramentas de lutas, como por exemplo, o Plano Nacional de Políticas para as Mulheres, a política Nacional de Promoção da Igualdade Racial, o Plano Nacional de Igualdade Racial e o Estatuto da Igualdade Racial. Este último dispõe sobre as questões fundiárias urbanas com o viés racial, parte do pressuposto de que nas favelas e cortiços há uma grande concentração de afrodescendentes. Para além desses motivos, o reconhecimento da identidade desenvolverá uma base mais forte de solidariedade coletiva e aprofundará a mobilização política desta comunidade.

Desse modo, a percepção de uma identidade afrodescendente, a resistência feminina, espelhada pelas guerreiras da Estradinha, poderá ser fortalecida em seus ideais de permanência, ajudando-as a compreender os outros fatores que estão sub inseridos no contexto da remoção. Assim, observarão com mais clareza que não se trata apenas das questões econômicas, trazidas pela valorização imobiliária demasiada. Mas, também de um pensamento racista, classista e sexista difundido nas bases do poder local, que utiliza um argumento falso, como o da área de risco, para remover a população negra, feminina e pobre das áreas privilegiadas da cidade e realocar em locais sem infraestrutura e serviços públicos que atendam ao conceito de moradia adequada.

${ }_{111}$ Ibid. p.174-176.
${ }^{112}$ Ibid. p. 198 


\section{Considerações Finais}

O direito à moradia no Brasil, apesar de incorporar todos os prérequisitos estabelecidos internacionalmente através da ONU-HABITAT, de vários tratados de direitos humanos, da Constituição Federal e da legislação infraconstitucional, encontra dificuldades para ser efetivado. Nesse contexto, com a chegada dos megaeventos esportivos à cidade do Rio de Janeiro, e, por conseguinte, da especulação imobiliária, a fim de padronizar os espaços urbanos para o mercado mundial, as favelas tornaram-se alvo das políticas de remoção. Essas intervenções autoritárias na dinâmica urbana tendem a expropriar os moradores de favelas do seu pertencimento à cidade, afetando diretamente o seu direito à moradia adequada.

Em meio a este panorama, a comunidade da Estradinha se mantém resistindo às iniciativas arbitrárias do poder municipal carioca. Através da articulação com instituições de defesa de direitos, tais quais, Defensoria Pública e Ministério Público e também da união de seus moradores, esta favela vem tornando-se referência. Assim, ao identificar quem é essa população deslocada e qual a influência das suas características nesse procedimento de realocação das centenas de famílias para locais distantes das áreas nobres da cidade, percebe-se que a política de remoção atua de forma discriminatória em várias categorias.

Exemplificando através do caso da Estradinha, uma comunidade que em sua maioria é afrodescentente, feminina e pobre, a política de remoção demonstra um caráter interseccional, que invisibiliza as vítimas. Ou seja, o resultado da combinação dos diversos tipos de opressão é a invisibilidade dessas mulheres, enquanto sujeito de direitos. Os impactos negativos decorrentes da política municipal, afeta diretamente as mulheres que são vulnerabilizadas por causa dessas ações. Essa vulnerabilidade pode ser expressa através da desagregação dos laços comunitários, das redes de solidariedade que, por sua vez, chegam a afetar a saúde física e mental de seus moradores. 
Desta forma, o poder público desrespeita as premissas que envolvem o conceito de moradia adequada, principalmente no que tange ao princípio da não discriminação e à priorização de grupos vulneráveis. Em contrapartida aos ataques da Prefeitura, a comunidade, liderada pelas mulheres que moram no local, se organiza e combate o desrespeito ao seu direito, mantendo-se numa posição de resistência.

A fim de manter a união e o ativismo da Estradinha, é importante que os seus moradores percebam/construam a sua identidade racial, para que também possam enfrentar a questão do racismo, que apesar de impregnada nas políticas de remoção, torna-se invisível pela sobreposição de outras opressões, tais como a de classe e de origem geográfica, de acordo com a teoria da interseccionalidade.

A percepção/construção das identidades racial e de gênero, nesta comunidade, poderá fortalecer ainda mais o protagonismo dessas mulheres na luta pelo direito à moradia das suas famílias. Do mesmo modo, continuará conduzindo a um processo de empoderamento das mulheres, ainda tão discriminadas, por pertencer ao povo da favela. 


\section{Referências bibliográficas}

ARRIAGADA, Irma. Dimensiones de la pobreza y políticas desde uma perspectiva de gênero. Reunión de Expertos "Políticas y programas de superación de la pobreza desde la perspectiva de la gobernabilidad democrática y el género". Comisión Económica para América Latina y el Caribe - CEPAL. 2004. P.02. Disponível em: http://www.cepal.org/mujer/reuniones/quito/IArriagada2.pdf.

BRAH, Avtar; PHOENIX, Ann. Ain't I a Woman? Revisiting Interseccionality. Journal of International Women's Studies. Vol. 5 No. 3. Publicado em Maio/2004. P. 76. Disponível em: http://www.bridgew.edu/soas/jiws/may04/phoenix_brah.pdf. Acessado em: 27.03.2013.

CAMPOS, Andrelino O. O Planejamento Urbano e a "Invisibilidade" dos Afrodescendentes - Discriminação étnico-racial, intervenção estatal e segregação socioespacial na cidade do Rio de Janeiro. 2006. p. 14. Disponível em: http://www.ppgg.igeo.ufrj.br/index.php?option=com docman\&task=doc d etails\&gid=72\&Itemid=99999999. Acessado em: 29.05.2013.

CAMPOS, Maurício. Relatório sobre a visita técnica realizada na comunidade da Ladeira dos Tabajaras (Estradinha 1014, Botafogo) em 10 de Maio de 2010, e Parecer Técnico sobre os motivos alegados pela Prefeitura do Rio de Janeiro para a remoção completa da comunidade. p. 01. (material cedido pelo autor - não publicado)

CENSO DEMOGRÁFICO 2010. Aglomerados Subnormais - Primeiros Resultados. IBGE, Rio de Janeiro, 2011. p.19. Disponível em: http://biblioteca.ibge.gov.br/visualizacao/periodicos/92/cd_2010_aglomerad os_subnormais.pdf. Acessado: 25/04/2013.

COMO DELIMITAR E REGULAMENTAR ZONAS ESPECIAIS DE INTERESSE SOCIAL - ZEIS DE VAZIOS URBANOS. Ministério das Cidades. Brasília 2009. Disponível em: https://www.google.com.br/url?sa=t\&rct=j\&q=\&esrc=s\&source=web\&cd= $3 \& \mathrm{cad}=$ rja\&ved=0CDgQFjAC\&url=http $\% 3 \mathrm{~A} \% 2 \mathrm{~F} \% 2 \mathrm{Fwww} \cdot \mathrm{mp} . \mathrm{mg} . \mathrm{gov} \cdot \mathrm{br}$ $\% 2$ Fportal\%2Fpublic\%2Finterno\%2Farquivo\%2Fid\%2F14599\&ei=AeWv UZSsE9H94APSwoGQDA\&usg=AFQjCNGsnmSkXsB1SzrZWi3gfClXCn O8Yw\&sig2=cKtnkB9mZ1D3MW5AC04sZw\&bvm=bv.47534661,d.dmg. Acessado em: 21/04/2013. 
CONSTITUIÇÃO DO ESTADO DO RIO DE JANEIRO. 1989. Assembleia Legislativa do Estado do Rio de Janeiro. Disponível em: http://www.cmresende.rj.gov.br/PDF/const_est_rj.pdf. Acessado em: 29/04/2013.

CONVENÇÃO SOBRE A ELIMINAÇÃO DE TODAS AS FORMAS DE DISCRIMINAÇÃO CONTRA A MULHER (CEDAW). Disponível em: http://www.pge.sp.gov.br/centrodeestudos/bibliotecavirtual/instrumentos/di scriraci.htm. Acessado em 19/04/2013.

CONVENÇÃO SOBRE A ELIMINAÇÃO DE TODAS AS FORMAS DE DISCRIMINAÇÃO RACIAL (1968).

Disponívelem:http://www.pge.sp.gov.br/centrodeestudos/bibliotecavirtual/i nstrumentos/discriraci.htm.Acessado em: 22.03.2013.

CORTEZ, Mirian Béccheri e SOUZA, Lídio de. Mulheres (in)subordinadas: o empoderamento feminino e suas repercussões nas ocorrências de violência conjugal. Psic.: Teor. e Pesq. [online]. 2008, vol.24, n.2, pp. 171-180. ISSN 0102-3772. Disponível em: http://www.scielo.br/pdf/ptp/v24n2/05.pdf

CRENSHAW, Kimberle. A Intersecionalidade da Discriminação de Raça e Gênero. P.9. Disponível em: http://static.tumblr.com/7symefv/V6vmj45f5/kimberle-crenshaw.pdf. Acessado em: 12.03.2013.

CRENSHAW, Kimberle. Documento para o Encontro de Especialistas em Aspectos da Discriminação Racial relativos ao Gênero. 2002. P.172. Disponível em: http://www.scielo.br/pdf/ref/v10n1/11636.pdf.

CUESTIONARIO SOBRE LA VIVIENDA ADECUADA Y LA MUJER. p.01. Disponível em: http://direitoamoradia.org/?p=6563\&lang=es. Acessado em: 07/05/2012.

DYMINSKI, Andrea Sell. Noções de Estabilidade de Taludes e Contenções. p.01. Disponível em: http://www.cesec.ufpr.br/docente/andrea/TC019/TC019/Taludes.pdf. Acessado 25/05/2013

ESTATUTO DA CIDADE COMENTADO. Ministério das Cidades Governo Federal. 2010. p.91. Disponível em: http://www.cidades.gov.br/images/stories/ArquivosSNPU/Biblioteca/Planel amentoUrbano/EstatutoComentado_Portugues.pdf. Acessado em: 28/04/2013.

ESTATUTO DA IGUALDADE RACIAL. Secretaria Especial de Políticas de Promoção da Igualdade Racial - SEPPIR. Disponível em: 
http://www.planalto.gov.br/ccivil_03/_Ato2007-

2010/2010/Lei/L12288.htm. Acessado em: 29/04/2013.

FORCED EVICTIONS QUESTIONNAIRE. ONU-HABITAT. Disponível em:

http://www2.ohchr.org/english/issues/escr/docs/ForcedEvictionsAssessmen tQuestionnaire.pdf. Acessado em 05/05/2013.

GARCIA, Antonia dos Santos. Mulher Negra e o Direito à Cidade: Relações raciais e de gênero. IN: SANTOS, Renato Emerson dos (Org.). Questões Urbanas e Racismo. Petrópolis-RJ, 2012. Ed. De Petrus e Alii Editora. p. 140.

GONZALEZ, Lélia e HASENBALG, Carlos. Lugar de Negro. Rio de Janeiro, Marco Zero, 1982, p. 15

GUIMARÃES, Antônio Sérgio. Classes, Raça e Democracia. P.35-36. Disponível em: http://books.google.com.br/books?id=k7cEzL4awMAC\&pg=PP4\&lpg=PP4 $\& \mathrm{dq}=$ classes,$+\mathrm{ra} \% \mathrm{C} \% \mathrm{~A} 7 \mathrm{a}+$ edemocracia+antonio+sergio+guimar\% $\mathrm{C} 3 \% \mathrm{~A} 3$ es\&source $=$ bl\&ots $=511 \mathrm{CCuDv} \&$ sig=SPIEMv9vogx69imZXsIVZjzyo\&hl= pt\&sa $=X \&$ ei=v8p1UcCPDaeV0QGcp4DABA\&redir_esc=y. Acessado em: 18.03.2013.

HOFFMANN, Florian. Interseccionalidade Sistêmica? Breves Comentários Sobre a Luta Contra a Discriminação Racial no Âmbito Internacional. In: Notícias e Reflexões Sobre Discriminação Racial. Ed. PUC-RIO, 2008. Pp. 105.

LEI ORGÂNICA DO MUNICÍPIO DO RIO DE JANEIRO. Procuradoria Geral do Município do Rio de Janeiro. 2010. Disponível em: http://200.141.78.79/dlstatic/10112/1659124/DLFE-

222901.pdf/LeiOrganica.pdf. Acessado em: 28/04/2013.

MUJERES Y EL DERECHO A UNA VIVENDA ADECUADA. Disponível em: http://direitoamoradia.org/wpcontent/uploads/2013/01/OHCHR_Mujeres-y-el-derecho-a-una-viviendaadecuada.pdf. p. 39.

MUNANGA, Kabengele. Uma Abordagem Conceitual das Noções de Raça, Racismo, Identidade e Etnia. Disponível em: http://www.geledes.org.br/component/rsfiles/download?path=Umaabordagem-conceitual-das-nocoes-de-raca-racismo-dentidade-eetnia.pdf\&Itemid=573. Acessado em: 16.03.2013. 
PAUGAM, Serge. Desqualificação Social: Ensaio sobre a nova pobreza. São Paulo. Ed. Cortez, 2003. P.45

PERRY, Keisha-Khan Y. Espaço urbano e memória coletiva: $O$ conhecimento de mulheres negras em lutas politicas. IN: SANTOS, Renato Emerson dos (Org.). Questões Urbanas e Racismo. Petrópolis-RJ, 2012. Ed. De Petrus e Alii Editora. p. 170

PLANO NACIONAL DE POLÍTICAS PARA AS MULHERES. Secretaria Especial de Políticas para Mulheres. Brasília. 2005. p.13.Disponívelem:http://bvsms.saude.gov.br/bvs/publicacoes/pnpm_comp acta.pdf. Acessado em 29/04/2013.

POLÍTICA NACIONAL DE HABITAÇÃO. p.29. Ministério das Cidades Governo Federal. 2004. Disponível em: http://www.cidades.gov.br/images/stories/ArquivosSNH/ArquivosPDF/4Po liticaNacionalHabitacao.pdf. Acessado 22/04/2013.

POLÍTICA NACIONAL DE PROMOÇÃO DA IGUALDADE RACIAL (PNPIR). Secretaria Especial de Políticas de Promoção da Igualdade Racial (SEPPIR). Brasília. 2003. Disponível em: http://www.planalto.gov.br/seppir/pnpir/pnpir_programa/objetivo.htm. Acessado em: 29/04/2013.

SCOTT, Joan. Gênero: Uma Categoria Útil para Análise Histórica. P. 04. Disponível em: http://wesleycarvalho.com.br/wpcontent/uploads/G\%C3\%AAnero-Joan-Scott.pdf. Acessado em 19.04.2013.

SILVA, José A. da. Curso de Direito Constitucional Positivo. 29ª Edição. Ed. Malheiros. São Paulo. 2007. P. 314

THE RIGHT TO ADEQUATE HOUSING. ONU-HABITAT. Disponível em:http://www.ohchr.org/Documents/Publications/FS21_rev_1_Housing_e n.pdf. p. 03. Acessado em: 23/03/2013.

YUVAL-DAVIS, Nira. Intersectionality and Feminist Politics. European Journal of Women's Studies, 2006. P. 199. Disponível em: http://ejw.sagepub.com/content/13/3/193.

$\underline{\text { Sites pesquisados: }}$

http://direitoamoradia.org/?page_id=46\&lang=pt

http://direitoamoradia.org/wp-content/uploads/2012/01/guia-mulheresPT.pdf. 
http://direitoamoradia.org/wp-

content/uploads/2012/01/GUIA_REMOCOES_portugues_20119.pdf.

http://direitoamoradia.org/wp-content/uploads/2012/05/General-Comment7.pdf.

http://direitoamoradia.org/wp-content/uploads/2012/05/General-Comment7.pdf. p. 02. Acessado em: 21/03/2013.

http://direitoamoradia.org/wp-

content/uploads/2012/01/GUIA_REMOCOES_portugues_20119.pdf. p. 05. Acessado em: 25/03/2013.

http://ipprio.rio.rj.gov.br/o-instituto-2/historia/ Acessado em: 20/05/2013.

http://portalgeo.rio.rj.gov.br/sabren/. Acessado em: 20/05/2013

http://talusnopantanal.blogspot.com.br/2012/10/o-que-e-talus.html.

http://www.armazemdedados.rio.rj.gov.br

http://www.brasil.gov.br/secoes/mulher/atuacao-feminina/retrato-dasbrasileiras. Acessado em: 25/04/2013.

http://www.dhnet.org.br/direitos/sos/moradia/trabalhohabitacaopronto.html \#8

www.rio.rj.gov.br/habitacao/favela_bairro.htm. Acessado em 21/04/2013. http://portalgeo.rio.rj.gov.br/sabren/. Acessado em: 20/05/2013

http://www.onu.org.br/documentos/carta-da-onu/

http://www.unhabitat.org/downloads/docs/6821_99545_Gender\%20Equalit y\%20PORT.pdf

http://www.unfpa.org.br/Arquivos/pacto_internacional.pdf.

http://www.unhabitat.org/categories.asp?catid=10.

http://www.unhabitat.org/content.asp?typeid=19\&catid=10\&cid=927.

http://unicrio.org.br/img/DeclU D HumanosVersoInternet.pdf.

http://www.unric.org/html/portuguese/uninfo/DecdoMil.pdf. 


\section{Anexos}

Anexo I - Laudo I da GEO-RIO

Anexo II - Laudo II da GEO-RIO

Anexo III - Relatório do Engenheiro Maurício Campos

Anexo IV - Relatório do Engenheiro Alexandre Pessoa

Anexo V - Relatório do CREA

Anexo VI - Material de Identificação do Morro dos Cabritos - Programa

Favela-Bairro (Instituto Pereira Passos)

Anexo VII - Histórico da Comunidade da Estradinha (Cedido pela

Associação de Moradores)

Anexo VIII - Relatório da Comissão Permanência da Estradinha (Cedido

pela Associação de Moradores

Anexo IX - Entrevista com as moradoras da Estradinha 